\title{
Changing estuaries, changing views
}

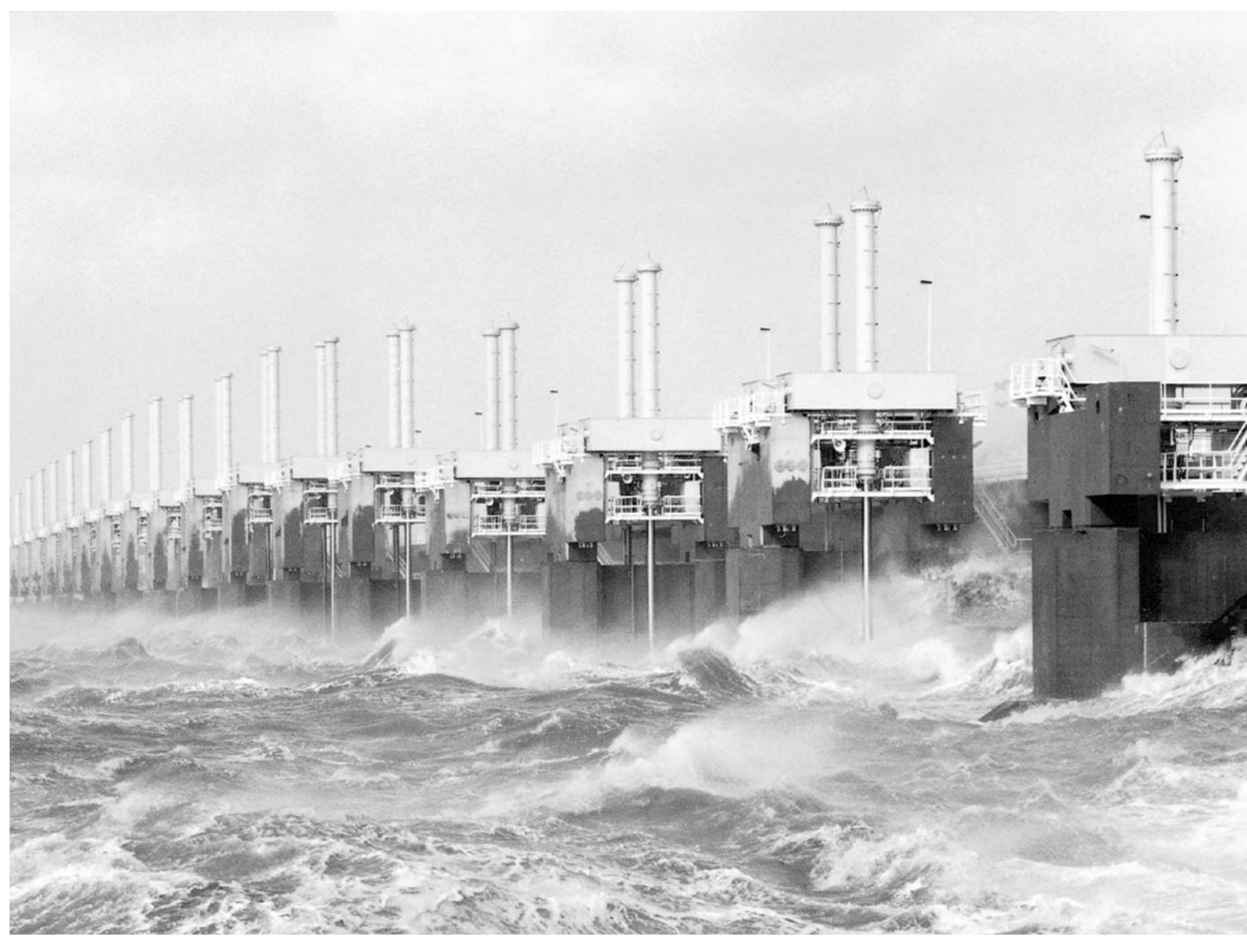

Erasmus University, Rotterdam \& Radboud University, Nijmegen commissioned by the Worldwide Fund for Nature, The Netherlands 


\section{Contents}

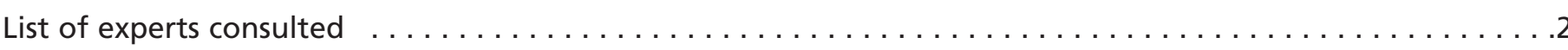
List of figures

Summary

1 Introduction

2 Morphology and man-induced changes

3 Ecology: where river and sea meet

3.1 The physical and ecological processes of an estuary

3.2 Impact of the Delta Works

3.3 Evolution of the newly created systems

3.3.1 The isolated lakes: compartments

3.3.2 The semi-open branch: the Eastern Scheldt

3.3.3 The open branch: the Western Scheld

4 Socio-economic developments

4.1 Use of the delta resources

4.1.1 Use of the wealth of the sea: fishery

4.1.2 The need for new land: agriculture

4.1.3 Trade, industry and shipping

4.1.4 A new industry arises: recreation ....

4.2 Delta economics

4.2.1 Non-delta economics in the delta. .

Delta Works . . . . . . . . . . . . 30

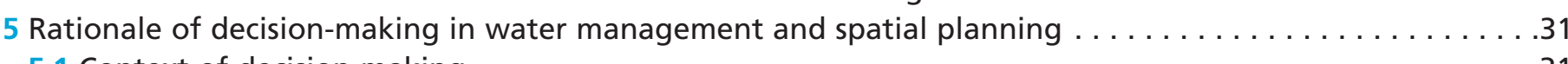

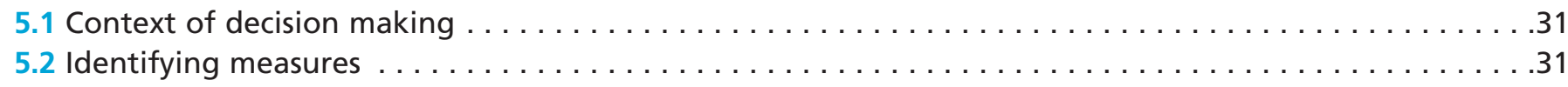

5.3.1 The cost-benefit analysis of the Delta Works

6 Decision-making processes in a changing context

6.1 Declining safety

6.11 Improved safety leads to new investments: risks are growing $\ldots$

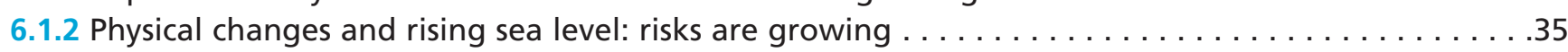

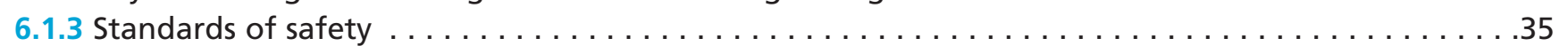

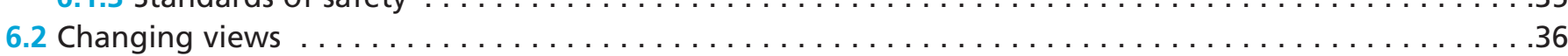

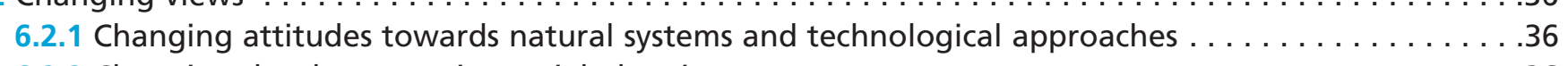

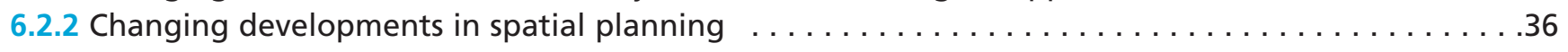

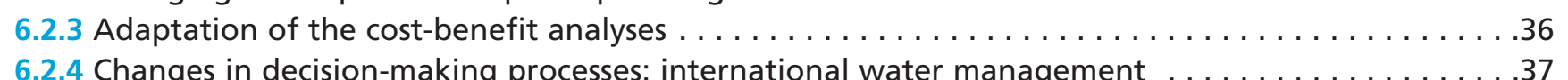

6.2.4 Changes in decision-making processes: international water

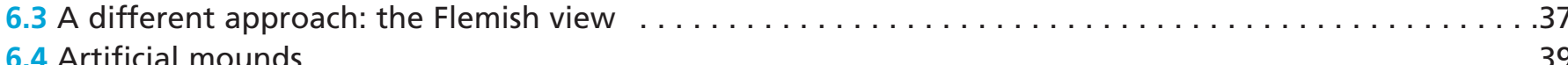

6.4 Artificial mounds

7 Lessons learned and solutions proposed

7.1.1 The values of a natural delta

7.1.2 Changes in knowledge and attitudes

1.3 Alternative approaches: a society in balance with nature

7.1.3.2 Changes in land use: floating cities and living on hills

7.1.3.3 Using the natural processes optimally: exchanging polders

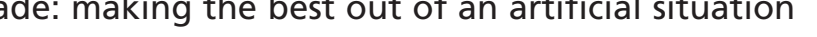

7.2.

7.2.3 Allow the natural processes still present to develop

7.2.4 Reduce eutrophication in the compartments

7.2.5 Find suitable land-use scenarios

\section{.3
.4
.9}




\section{Editors}

- Henk Saeijs

- Toine Smits

- Daphne Willems

\section{List of experts consulted}

- Ir. L.A. Adriaanse (Directorate-General for Public Works and Water Management, Zeeland Directorate) - drs J.P. Al (Directorate-General for Public Works and Water Management, Zuid-Holland Directorate) - Dr. J.A. van Ast (Erasmus Centre for Sustainability and Management, Erasmus University, Rotterdam) - Dr. J. Beijersbergen (Province of Zeeland)

Lic. Erika Van den Bergh (Institute of Nature Conservation, Brussels)

Dr. Ir. T.S. Blauw ( Province of Zeeland)

- Prof. G. Borger (University of Amsterdam)

- Prof. Dr. J.J. Bouma (Erasmus University Rotterdam)

- Ir. R. Brouwer (Institute for Inland Water Management and Waste Water Treatment)

- Prof dr. Dronkers (National Institute for Coastal and Marine Management)

- Dr. H. Drost (Institute for Inland Water Management and Waste Water Treatment)

- Prof. dr. V.N. de Jonge DSc (University of Groningen)

Dr. M.M. van Katwijk (Radboud University, Nijmegen)

Drs. J.W.M. Kuijpers (Directorate-General for Public Works and Water Management, Zuid-Holland Directorate)

Prof. Dr. P.H. Nienhuis (Radboud University, Nijmegen)

- Prof dr. P. Meire (Antwerp University)

- Prof. dr. H.L.F. Saeijs (Erasmus University, Rotterdam)

- Prof. dr. A.J.M. Smits (Centre for Water and Society, Radboud University, Nijmegen)

Drs l. de Vries (National Institute for Coastal and Marine Management)

\section{List of figures}

fig. 1 The North Sea

1953 disaster

fig. 3 Here rule over the sea, the moon, the wind and we

fig. 4 Haringvliet sluices, 1976

fig. 5 Freshwater tidal area with floodplain forest, River Durme

fig. 6 Industry on a high artificial mound, Terneuzen

fig. 7 The North Sea at the end of the last ice age

fig. 8 Sandbanks along the Western Scheldt

fig. 9 The estuary $6000 \mathrm{BC}$

fig. 10 The estuary $4500 \mathrm{BC}$

fig. 12 The estuary $50 A D$, Roman times

fig. 13 The estuary $350 A D$

$\begin{array}{ll}\text { fig. } 14 & \text { The estuary } 1000 \mathrm{AD} \\ \text { fig. } 15 & \text { The estuary of the Scheldt, Rhine and Meuse in } 1560\end{array}$

fig. 16 The estuary of the Scheldt, Rhine and Meuse, 1560

by Jacob van Deventer

fig. 17 Learning by trial and disaster

fig. 18 Detail of a map by Lepoivre, showing breached dykes in 1530

fig. 19 Detail of the first military and topographical map, about 1837

fig. 20 The estuary in 1837

fig. 21 The flood of 1953 in the southern part of the North Sea

fig. 22 Flooded areas in 1953 and the answer: large dams

fig. 23 Breached dyke, 1953

fig. 24 The northernmost branches of the estuary

fig. 25 The southernmost branches of the estuary

fig. 26 The current situation in the estuary: compartments

fig. 27 The fore-delta in 1560

fig. 28 The fore-delta in 2004

fig. 29 New sandbanks in the fore-delta

fig. 30 On the tidal flats algae occur in high densities: up to 6 million cells on a square centimeter.

fig. 31 The relationship between nutrient supply (river discharge), turbidity (expressed in light extinction) and annual primary production (after De Jonge, 2000)

fig. 32 The number of brackish-water species, shown in relation to the size (in terms of average freshwater discharge) of the individual estuaries and outlets

fig. 33 Sturgeon, Acipenser sturio

fig. 34 Eelgrass, Zostera marina

fig. 35 Diadromous fish species

fig. 36 Brackish water marshes along the Western Scheldt

fig. 37 Development of the total area of salt marsh in the estuary

fig. 38 The Western scheldt with brackish water marsh and large vesse

fig. 39 Fishing for mussels on the Eastern Scheldt

fig. 40 Ecotourism: guided tour in the brackish water marshes

fig. 41 The Port of Rotterdam

fig. 42 The development of the port of Rotterdam: 1400 - 2004

fig. 43 A new economic function: recreation
fig. 44 Spatial distribution of red and green functions and services in the delta area

fig. 45 Whats is the price of enjoying a healthy ecosystem

fig. 46 Floodplain of the Flemish Scheldt tidal river with Controlled Inundation Areas

fig. 47 Controlled Inundation Area in use: the lower dyke near the river overflows, and the area behind it is

fig. 48 Scheme of the tidal Scheldt River: existing situation: danger of uncontrolled flooding

fig. 49 Controlled Inundation Area along the Scheldt River: protection against flooding

fig. 50 Reduced Controlled Tide: freshwater tidal areas along the Scheldt River

fig. 51 Making the best of an artificial situation

fig. 52 Polders given back to the freshwater tidal system in the Biesbosch area

fig. 53 Satellite view of the Rhine-Meuse-Scheldt estuary 


\section{Summary}

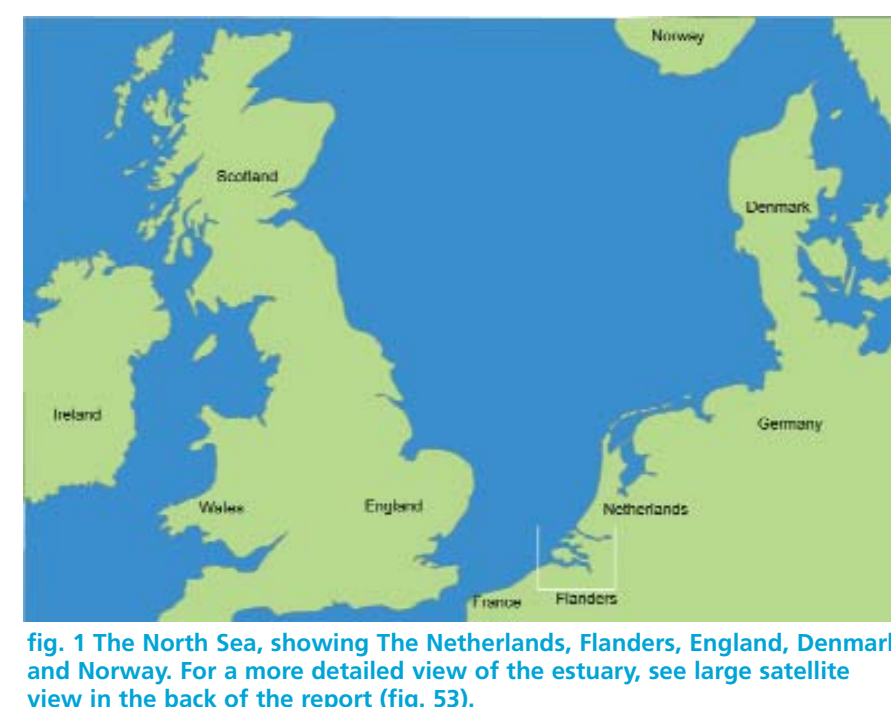

Dutch water management has an eventful history dating back over 1000 years. The enormous dams of the "Deltawerken" (the Delta Works) which were constructed in the estuary of the Rhine, Meuse and Scheldt during the last half century, brought Dutch water engineering expertise world fame (see fig. 53). As Dutch engineering firms were asked to plan and execute similar large water projects in other parts of the world, the skills and experience gained through the "Deltawerken" became a significant export product of The Netherlands. For many countries the Dutch approach became the model for water management technology.

Meanwhile, in The Netherlands itself, the disadvantages of large dams and closed-off estuarin branches became evident. The question therefore arises as to whether we should continue to export this approach

To answer this question, the Erasmus University Rotterdam (the Erasmus Centre for Sustainability and Management) in collaboration with the Radboud University of Nijmegen (Centre for Water and Society) commissioned by the Worldwide Fund for Nature (WWF) have analysed the history of human intervention in the estuary. Experts from the Ministry of Transport, Public Works and Water Management and Dutch and Flemish Institutions contributed to the analysis.

The hydromorphological, ecological and socioeconomic effects of traditional forms of water management in the estuary are described, and compared with an emerging new approach which focuses more on the morphological and ecologica dynamics of the estuarine system.

It is recognized that the decision, following the flood of 1953, to build a large, solid and inflexible "wall against the sea", when placed in the cultural context

4 Changing estuaries, changing views of the time, was understandable. The authors, inflexible is not the best solution in light of modern tandards and thinking. New insights in combinen with technological developments, call for a different strategy with better and more flexible results.

The "Deltawerken" are the culmination of a long tradition of land reclamation and defence against the sea. Almost the entire area of the land in the estuary was reclaimed from the sea by its inhabitants over a 1000-year history of constructing and repairing dykes in the muddy salt marshes. In this trial-and-error process, the hydrodynamic forces concentrated themselves in an east-west direction over the five main estuarine branches, in alternation with groups of islands that clustered together. The actual form of the branches and islands are the result of the interaction betw

The embankment of large parts of the former shallow sea brought sedimentation in these areas to a halt. The combination of a rising sea level and subsiding of the reclaimed land (especially the peat areas), dramatically changed the difference in levels between sea and land. Most land now lies far below the level of the sea.

From a socio-economic point of view, the impression of safety bestowed by the dykes, invites people to invest money behind them. Towns and villages prosper and tend to grow. Although the frequency of a potential disaster has diminished, the potential damage to lives and goods increases: the impression is therefore false. Especially in times of poor maintenance of the dykes (war, recession) this becomes only too obvious.

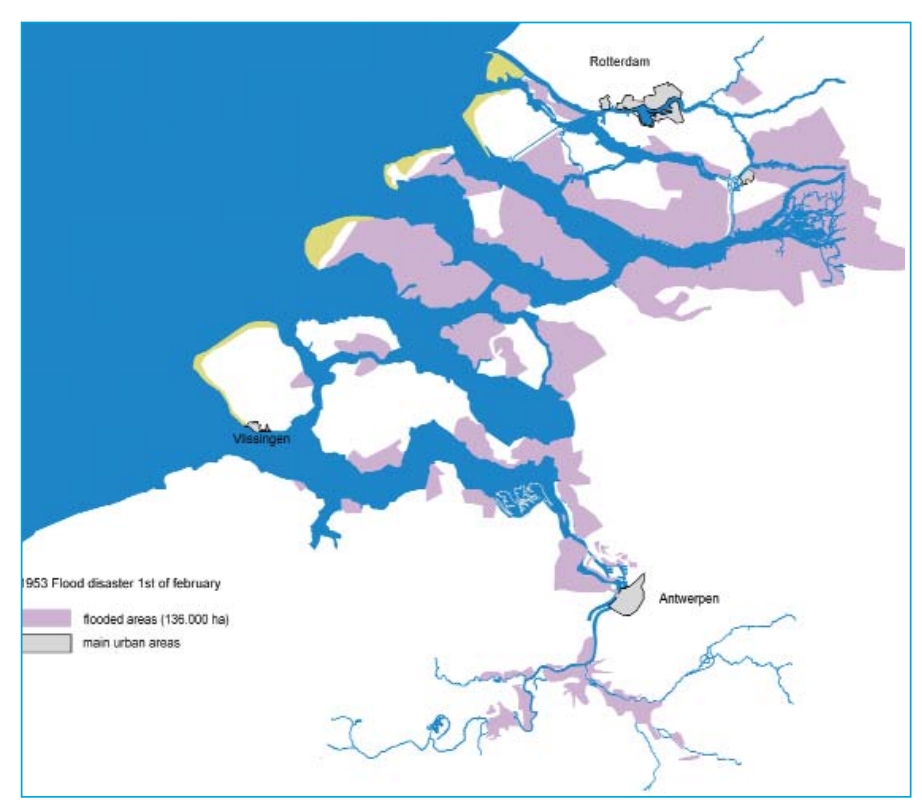

fig. 2 The extent of the 1953 disaster.

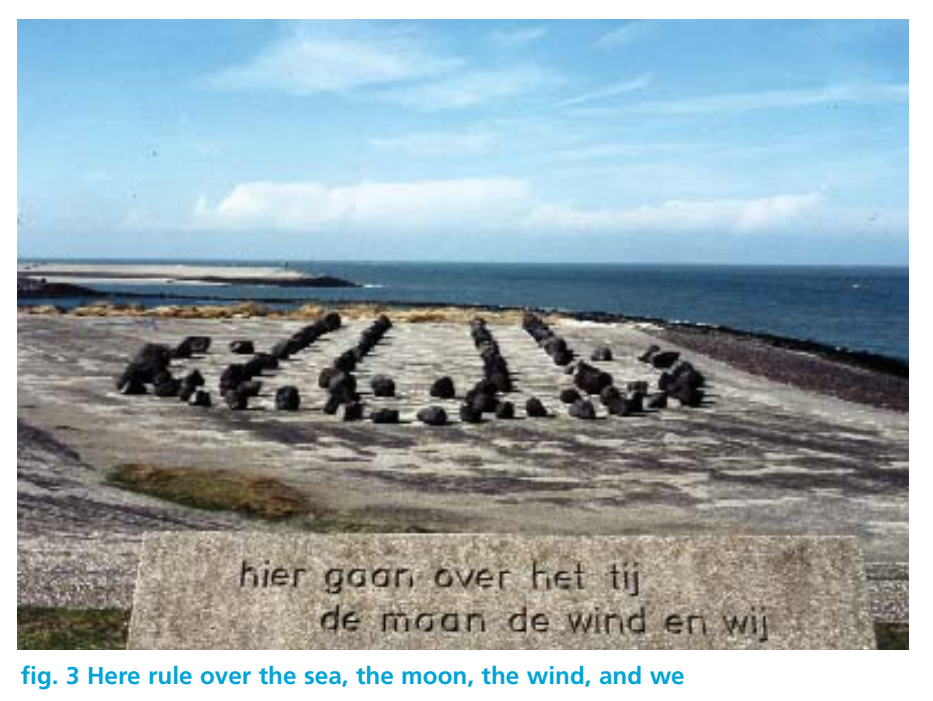

Safety norms for protection against flooding in The Netherlands are based on three main groups of arguments. Firstly, the probability of a certain water level being reached. Secondly, the construction and maintenance of dykes and dams and thirdly, the expected economic damage in case of a flood. In the heavily populated centres, the norm of once in 10,000 years is used. In regions with less expected damage, this norm is $1: 4000,1: 2500$ or even 1:1250. This mean that safety diminishes whenever investments are made in the lands protected by dykes. The expected sea level is recalculated regularly, and once every five years, by law, an evaluation of the condition of the dykes and sluices is made. If necessary, the constructions are changed or repaired. However, until now there has been no system of recalculating the potential economic damage.

In the 50 years after 1953, huge investments in trade, industry, and infrastructure were made. The population increased very considerably. Individuals took many decisions to invest behind the dykes. The government not only did nothing to prevent this development but, on the contrary, favoured this development. There is no exact calculation available, but probably the risk at this moment is far larger than it was in 1953.

Risk = probability $x$ effect. People feel safer if the probability of a disaster is lowered, but in fact the risks increase in proportion to growth in investments and population.

Storms that do almost no harm in a natural situation turn into catastrophes when dykes are breached. This has been the rule for a thousand years. A large number of such catastrophes are recorded, many in the 13th-17th centuries, and the last one in 1953. The answer was always: build higher and stronger dyk The consequence was always: more investments behind the dyke catastrophe.
The flood disaster of 1953 was not followed by an evaluation of traditional water / land management. Instead the event worked as a catalyst for the decision to persist with large-scale measures in the existing tradition: larger and more rigid dams. As an inscription in the concrete of the Easterscheldt dam says:

"here rule over the sea

the moon, the wind and we"

There was a strong conviction that technology would always be able to control the powers of the sea. It was, in fact this conviction that blinded the Dutch population to the real risks.

In the years before the 1953 disaster, two alternative solutions for improving the safety of the estuary were under discussion: enforcement of the existing dyk along the estuarine branches, or the closing of the solution was chosen. Probably the notion that, for the first time in history, technology made it possible. It fitted well into the traditional way of thinking. So, even before the disaster, the trend was towards closure of the main branches, although it was the more expensive solution

In the end, a hybrid decision was taken. Four of the five main branches would be cut of from the sea. The fifth, the western Scheldt, would remain open and the embankments would be reinforced over their full length. The economic interests of the harbour of Antwerp and the wish to maintain good internationa relations with Belgium prevailed. Rotterdam had its own open connection to the sea as well.

Only after the main decision was made was a costbenefit analysis carried out. Surprisingly, the analysis did not compare the different solutions; it simply calculated whether the costs of the chosen solution were in equilibrium with the expected benefits. And it was made to do so.

Closing the four main arms of the estuary brought an end to the natural transitions between fresh, brackish and salt water. Sediment transport stopped and large changes in the morphology began to develop. The original natural habitats disappeared, and were exchanged for man-made habitats. This was reflected in the biodiversity. Characteristic estuarine species disappeared, as was the case with species that travelled between the rivers and the sea. Species of more stable habitats established themselves.

The chosen solution, to cut off the estuary from the sea by large dams, is irreversible. The costs were so high that a reversal would mean a tremendous write-off of the investment. you can't do the same job twice. Secondly, changes in the use of the 


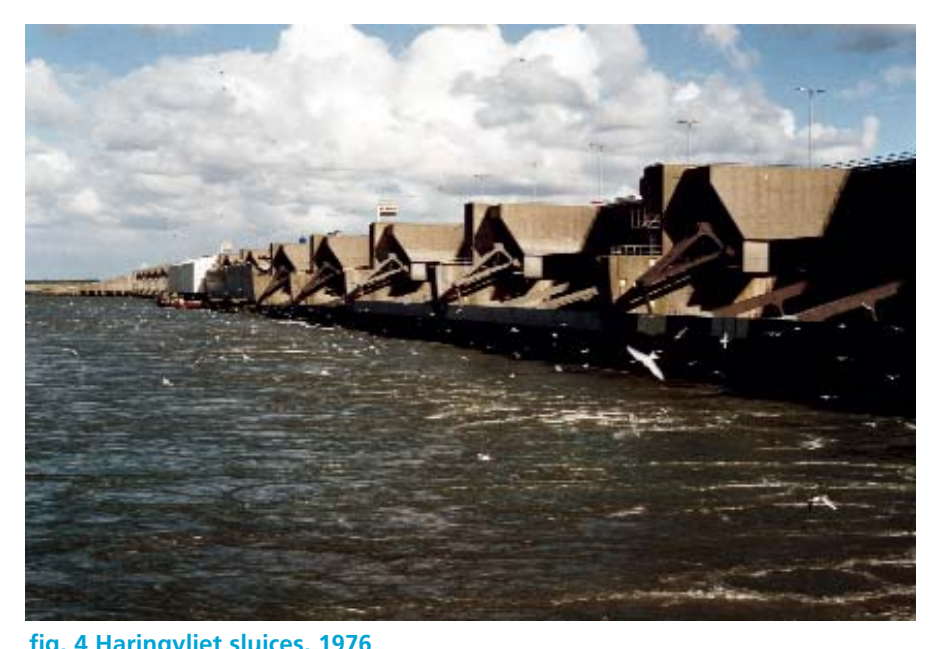

this branch. In fact, at this moment, the rare habitat of freshwater tidal marshes is re-generating on a large scale in the very heart of the densely populated urban region of Flanders.

In the meantime, another way of thinking has developed quite separately. Rotterdam is the largest port in the world, and the combination of the Netherlands and Flanders (Antwerp, Gent Bergen Zoom, Terneuzen, Sloe, Vlissingen, Zeebrugge) could be considered to be the second-largest harbour in the world. So, huge investments have been made in this area. But they have shown that captains of industry will not accept any risk of flooding at all. They interpreted the formula risk = probability $\mathrm{x}$ effect, in a better way. Refineries, oil terminals, nuclear plants, chemical industries, container terminals had to be entirely secure. They returned to a solution which was in use in the early Middle Ages: mounds. These are artificial hills which are high enough to remain dry during floods. Huge industrial mounds were constructed high above the sea.

When the darkest situation occurs, and the safetylimit of the dams (one in 10,000 years near Rotterdam and 1: 4000 years in other areas) is overtaken by an enormous storm, even these dams will break and the lands behind will become drowned in water meters deep. The damage will take many months to repair. The industrial complexes, however, on their artificial hills will, in the same worst case scenario, suffer a few centimetres of flooding during the few hours of high tide

Ironically, over the last 50 years, while industrial investments have been protected in this way, city planners have been building housing well below sea level.

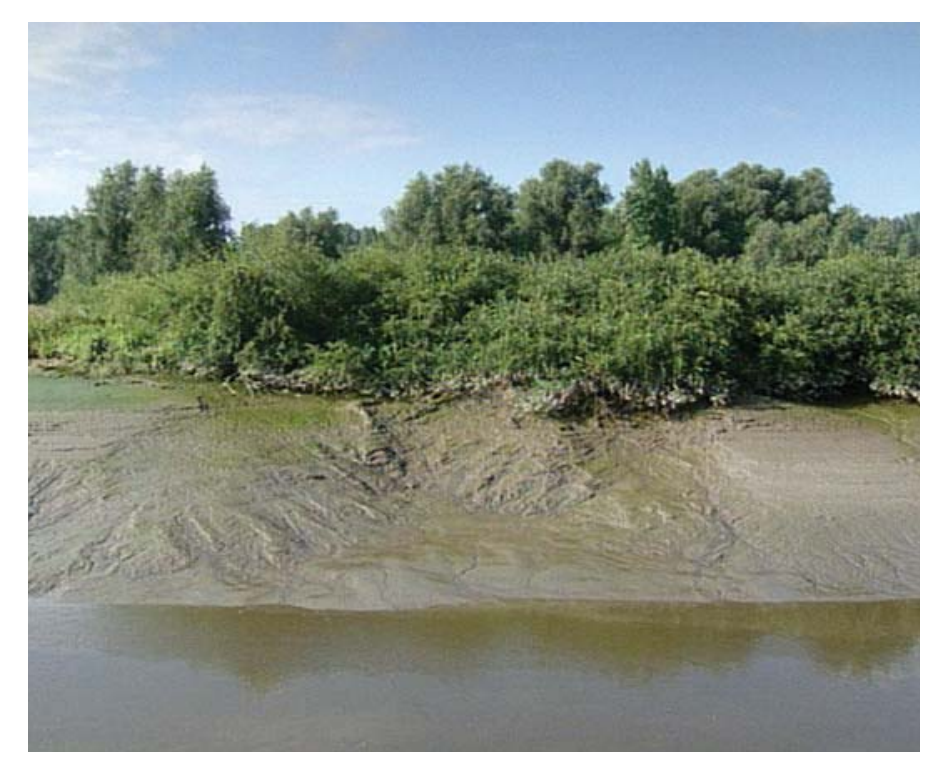

fig. 5 Freshwater tidal area with floodplain forest, River Durme

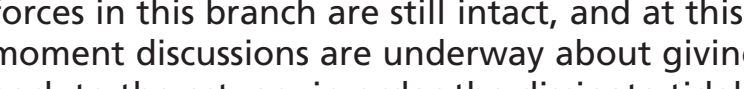

back to the estuary in order the dissipate tidal through sedimentation. land to rise with the sea

Such new ways of thinking can easily be implemented on a local scale without the loss of enormous investments. Changes in agricultural land use and adopted as part of a new approach to management

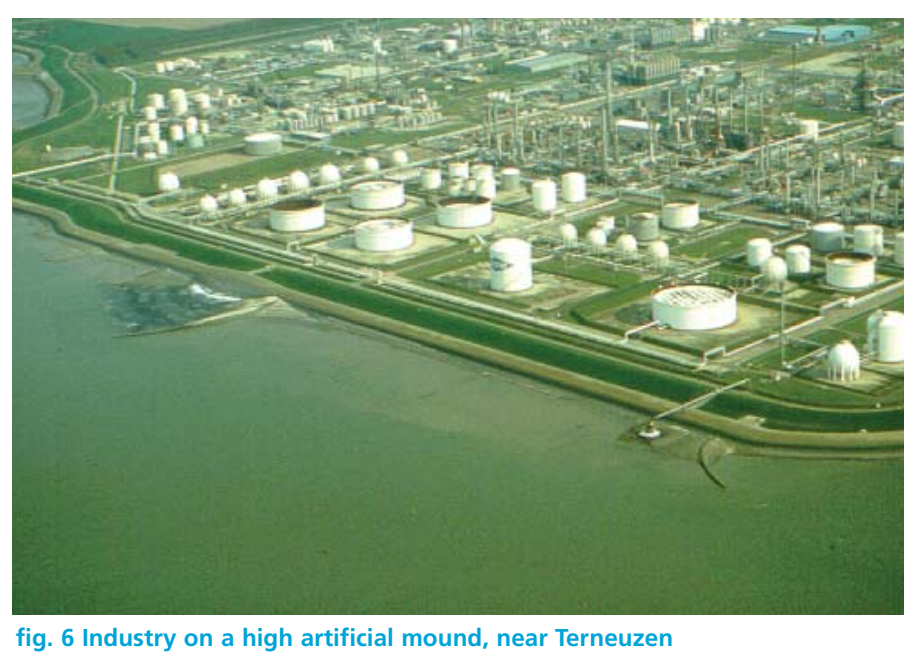

The authors have come to the following conclusions.

- Dykes safety.

- The huge dams may be technical masterpieces for control of the tidal dynamics of the sea, but they fail to control the socio-economic processes they unleash, and their existence is irreversible. The chance of flooding is reduced; the potential damage is enlarged, so the net result is zero or worse.

- The Delta Works approach underestimates the importance of long-term hydromorphological processes and changes: the height of the dams will have to be increased for eternity, and the lands behind them cannot grow with the rise of the sea.

- Maintenance and strengthening of the structures, and dealing with their unpredictable impacts, involve very high recurrent costs

- New approaches such as developed in the Western scheldt are far more flexible. New insights can be used, new techniques developed and implemented. Fifty years on, a completely new way of thinking about the management of estuaries can be applied there. Changes in the importance of agricultural land in the European context, offers an opportunity to give agricultural land back to the sea in order to absorb tidal energy and to allow the land to rise with the sea.
Industry took refuge on artificial mounds, the most ancient and the most modern way to survive waves and floods. This solution deserves to be thoroughly thought through as a long-term strategy for safe building in the low parts of The Netherlands and Flanders. A new urbanised landscape could emerge, where people and investments are located in safe places, surrounded by a landscape that is ruled by the forces of nature.

\section{Recommendations}

- If there is still is a choice, leave untouched estuaries and deltas alone. Investments should be made outside the morphologically active area.

If there is already a history of human intervention, try to adopt the most flexible approaches to safety and development. Sustainable land (and water) use is characterised by adaptation to the natural processes, and not vice versa.

Reversible and local measures within the limits of the natural processes are preferable. These need not be rustic, they can be as modern and hi-tech as necessary and possible. Floating cities, sea-encircled artificial mounds: everything is fine as long as the natural system is still functioning.

Huge investments in one direction may block return to a better solution. A cost-benefit analysis should assess not only the economics, but also the quality and flexibility of the solution.

The intrinsic value of natural processes cannot be calculated in money. The ethical and cultural significance of sound and complete natural systems should be valued on their own merits.

Public understanding of the natural system, and its engagement in management of it, facilitates decision-making processes.

A worldwide platform for politicians, industrialists and experts should be organised to study the management of estuaries and deltas, to exchange ideas, and to develop new ideas and techniques. As water management is traditionally exported by
The Dutch, The Netherlands and Flanders (Belgium) could take the lead in such an initiative. 


\section{Introduction}

For most people, the large engineering works built in the south west of The Netherlands to protect the region from flooding, represent the proud heritage of Dutch water

engineering: the eighth wonder of the world! Nevertheless, since their construction, new insights into natural processes and safety have developed which have shown that the consequences for the morphological and ecological characteristics of the system have also been enormous. Society has changed too: agriculture is no longer the most important economic activity and nature is more highly valued now than fifty years ago. The measures taken in the south west of The Netherlands are irreversible. However, can we envisage other ways of dealing with similar situations? Should we still be exporting large engineering projects? Could we, instead, implement at home, and export, a different, more sustainable approach to safety along the sea coasts?

\section{Goal of the study}

In this study we review the Dutch experience and, in light of the lessons learned, offer general advice about how to deal with delta regions worldwide.

\section{Structure of the report}

A description of the major changes observed in the south-western estuary opens the report (Chapter 2). The natural morphological characteristics and changes to them, many the result of human intervention, are discussed. For clarity, the delta is divided into several systems: the fresh, brackish and marine lakes (the compartments), the semi-closed Eastern Scheldt and the 'unaffected' Western Scheldt.

The ecological aspects of the systems are then described including the changes over time (Chapter 3).
The fourth chapter describes how the system has been exploited by people since the Middle Ages when transformation of the system had already started. Cultural aspects of the area are described here and their influence on decision-making processes.

The rationale underlying decision-making about land and water management is discussed in Chapter 5 . Special attention is given to cost-benefit analyses.

Chapter 6 presents a summary of the lessons learned based on historical developments and recent insights.

Finally, the lessons are translated into

recommendations for implementing sustainable development in estuaries in general (Chapter 7). 


\section{Morphology and man-induced changes}

2.1. The play of the waves: morphological processes

Approximately 10,000 years ago the sea water level was $45 \mathrm{~m}$ below the current Main Sea Level.

The rivers Rhine, Thames, Meuse and Scheldt were united into one large river that spilled into the far north of the North Sea. (fig. 7)

After the end of the last ice age, the waters of the sea started to rise. The land that connected mainland Europe with what later became the British Isles, was invaded by the North Sea from the north towards th south. From the other direction, south-west to northeast, the sea gradually flooded the English Channel and eventually connected with the North Sea.
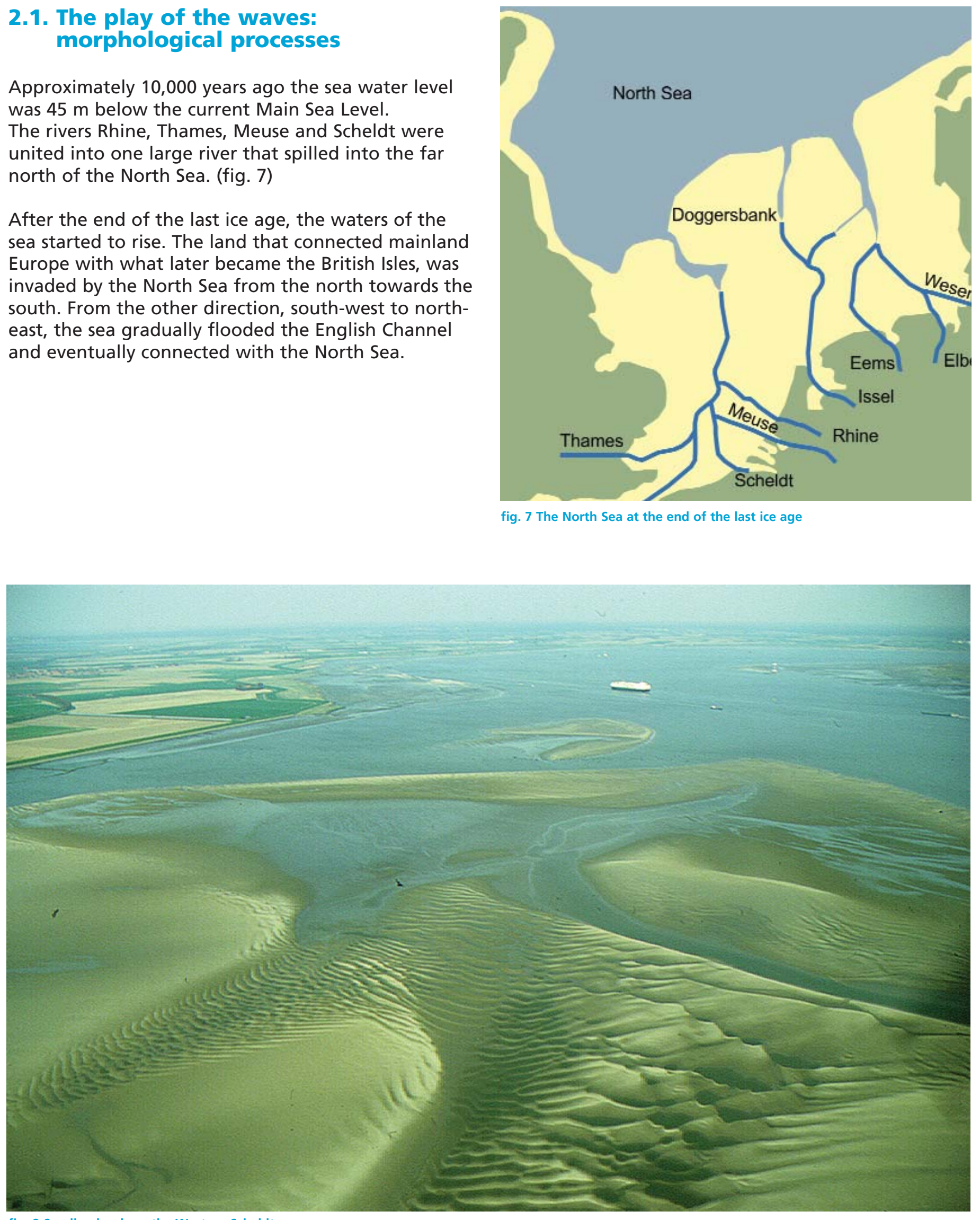


\section{Development of the Dutch-Flemish estuary between 6000 BC and AD 1000}

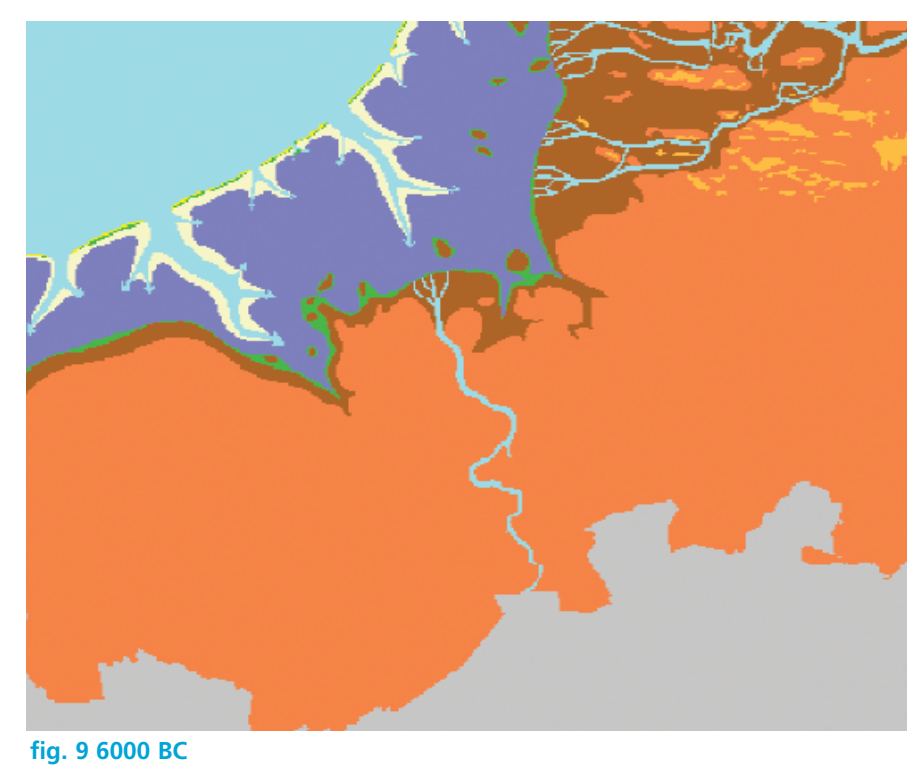

\author{
intertidal flats \\ saltmarshes with vegetation \\ peat-bog complexes
high pleistocene sand \\ sea, es
lagoon
}

After the ice age the level of the sea rose very fast in a short time. The land was only sparsely covered by vegetation. Erosion by water was strong and the rivers brought large amounts of sediment to the sea. Through the activity of wind, waves and currents a more or less closed range of sand ridges were formed parallel to the southern shores of the North Sea. Sedimentation volumes were large enough to compensate for sea-level rise. The sandy ridge moved slowly to the east.

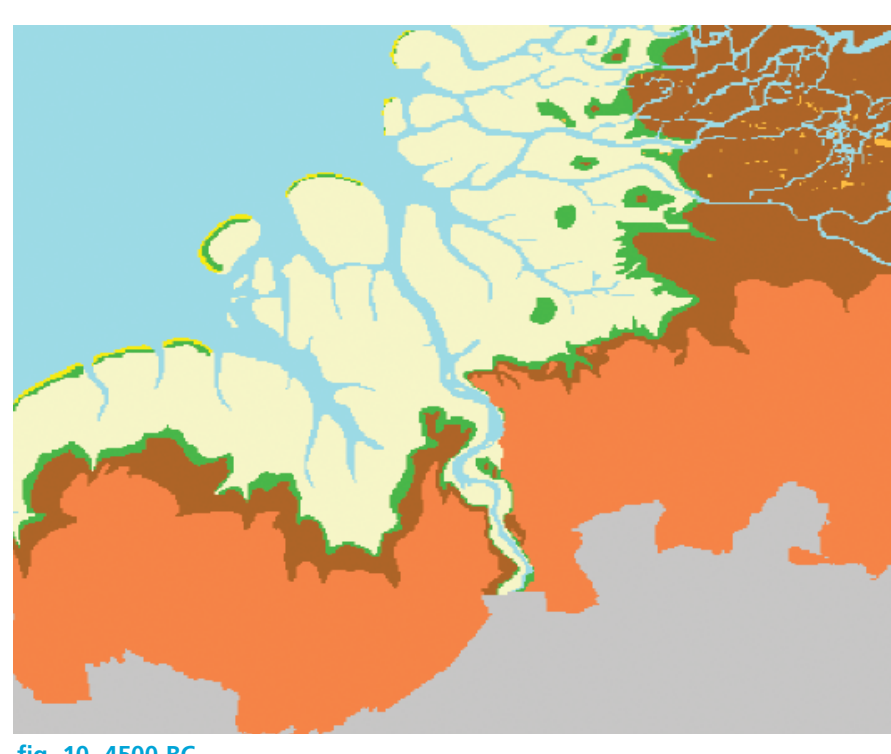

As the climate became warmer, the rate of sea-leve sediments by the rivers diminished. In the delta, the rise of the sea level exceeded the growth of the land fig. $104500 \mathrm{BC}$

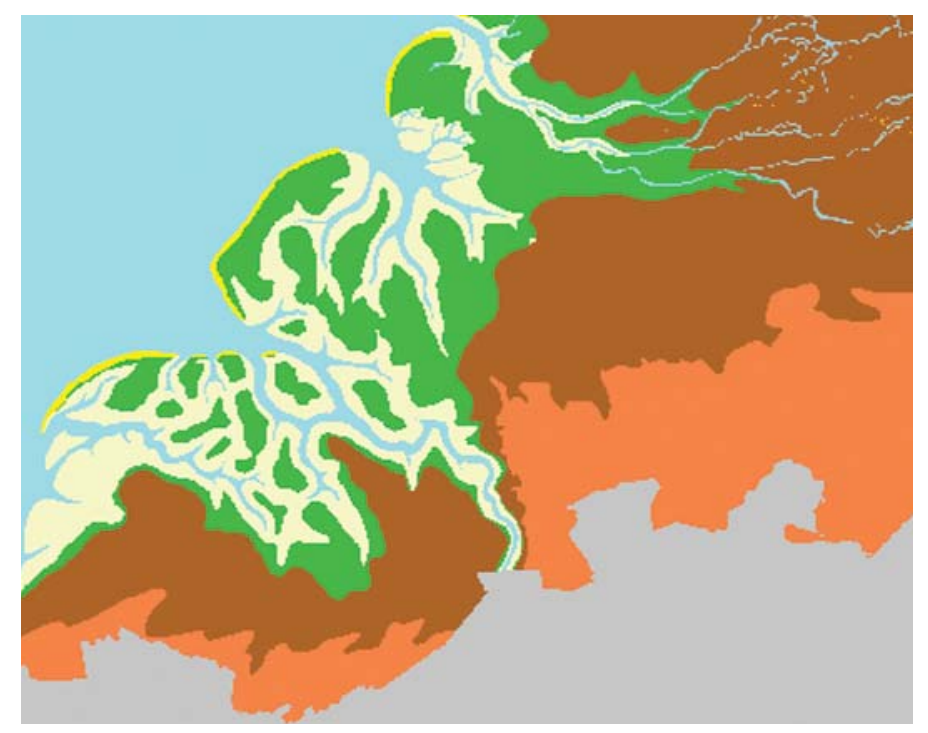

The land behind the sandy ridge was drowned by fresh water from the rivers. Extensive peat-bog

fig. $112500 \mathrm{BC}$
At the beginning of the Roman period, large peat-bog complexes covered the area behind the sandy ridge. The bogs rose several meters above the level of the sea Rivers found their way through to the sea. The Romans used the peat for fuel and for the production of salt. Ditches and canals were dug into the bogs to drain them for agricultural use. Through both shrinkage and oxidation the level of the bogs was lowered considerably.

After the collapse of the western part of the Roman Empire, the peat bogs were locally low enough to be flooded by the sea. Change of the climate and more rapid sea-level rise led to the erosion of extensive

areas of the peat in the southwestern estuary.

Where it was not eroded, the peat became salt-logged and covered with thick layers of sand and silt.

About the year 1000, the area consisted of a shallow sea with many branches. Large sections of the sandand siltbanks were covered with salt-resistan vegetation. These, the highest parts, were flooded only occasionally. From this time onward, people started to occupy both the salt marshes and the remaining bogs.
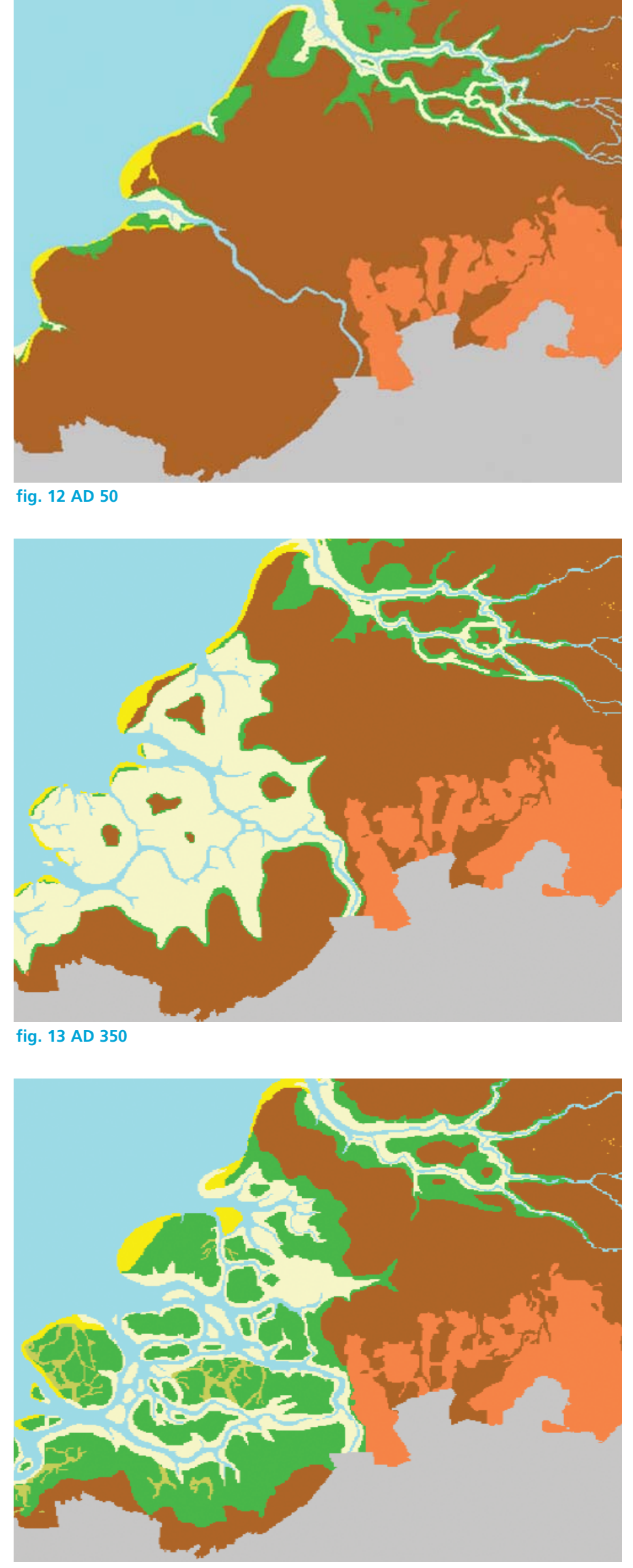

fig. 14 AD 1000 


\section{The Dutch-Flemish estuary from 1550 to 1850}

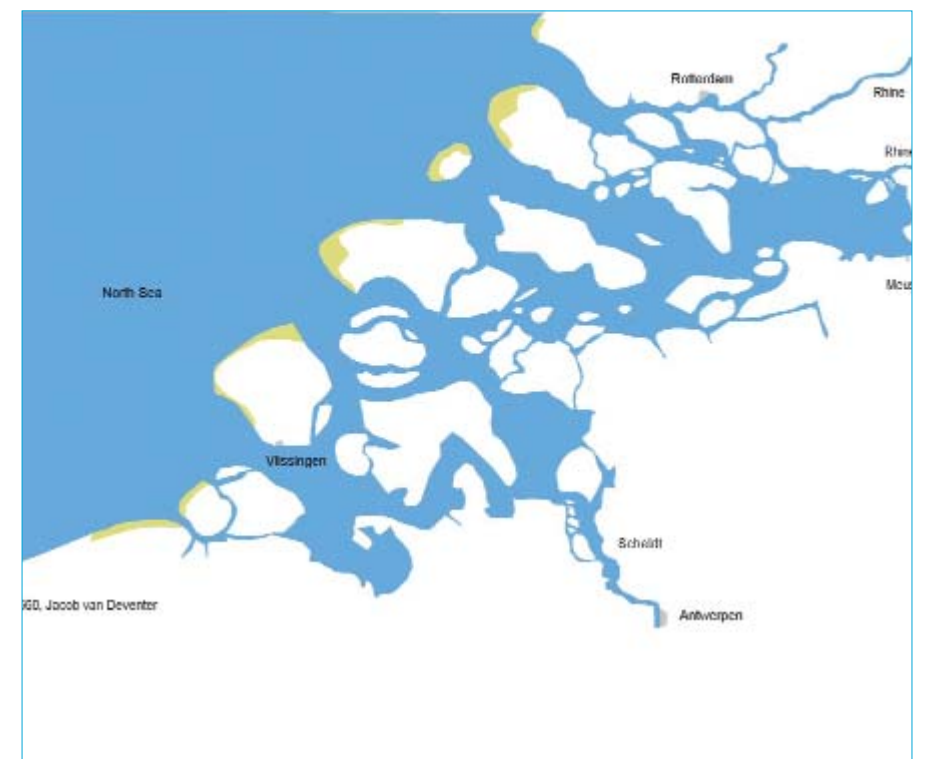

fig. 15 The estuary of the Scheldt, Rhine and Meuse in 1560

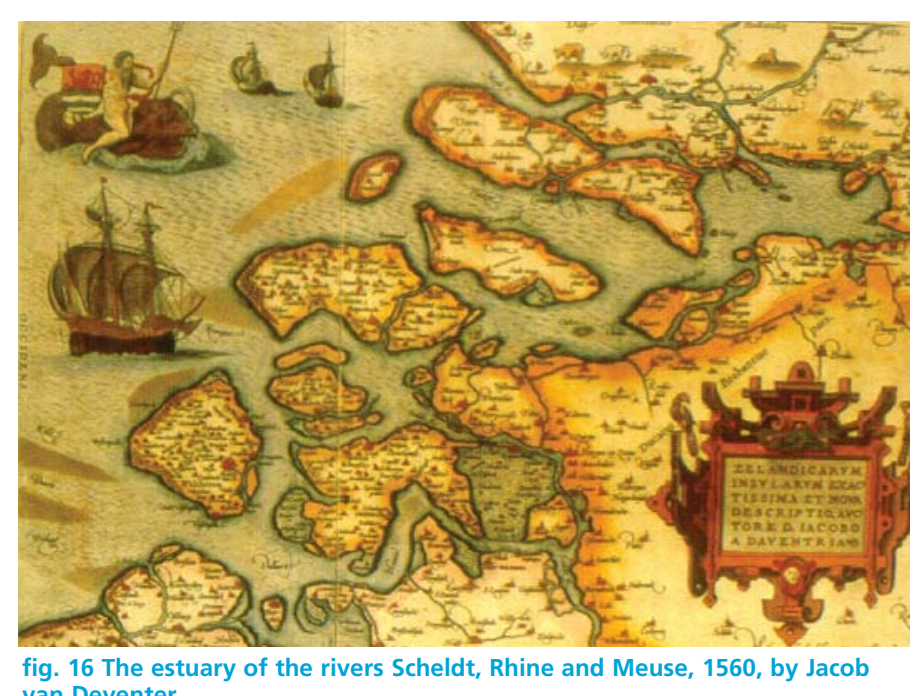

In the 16th century, cartography flourished in the Low Countries. Jacob van Deventer made countless detailed maps of villages, towns and islands. He was the ideal person to make an accurate regional map of the estuary.

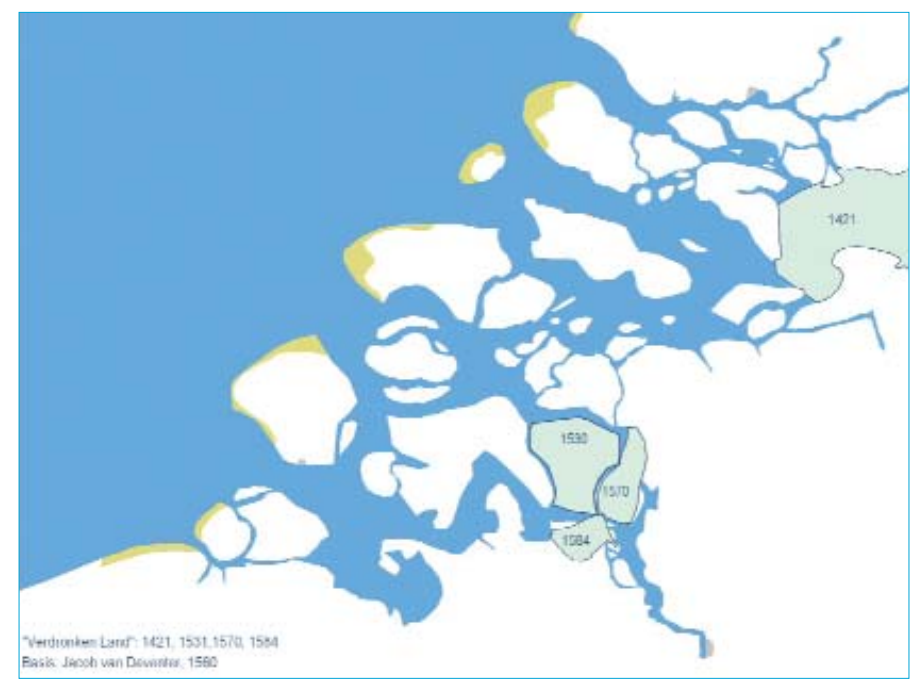

Dyke construction and land reclamation really was a battle against the sea.

Disastrous floods in 1375, 1404, 1421,1530, 1532,

1552, 1570 and many more smaller events, were answered by industrious repair of the damaged dykes. In the end, some areas proved impossible to maintain and they were given back to the sea.

In this battle between man and the sea, a pattern developed: tidal energy concentrated itself in the main branches and the "drowned" lands were foun fig. 17 Learning by trial and disaster at their landward ends, in the east.
This "Drowned land of Reimerswael" was given back to the sea and more of the surrounding land

underwent the same fate later in the 16th century. The emerging pattern of islands clustering together in an east-west direction, and estuarine branches that developed likewise, concentrated the tidal energy in the branches and directed it to the eastern end of the estuarine system.

In the 18th and 19th centuries, land reclamation continued. Land was so valuable that every morsel of saltwater marsh that grew high enough was immediately reclaimed. This practice went to the very edges of the system, leaving less and less place for floodwater to be stored and for its energy to dissipate.

In the 19th century most of the islands were clustered together. Only a few north-south connections between the estuarine branches remained. In the first half of the 20th century, a few large land reclamation projects were carried out.

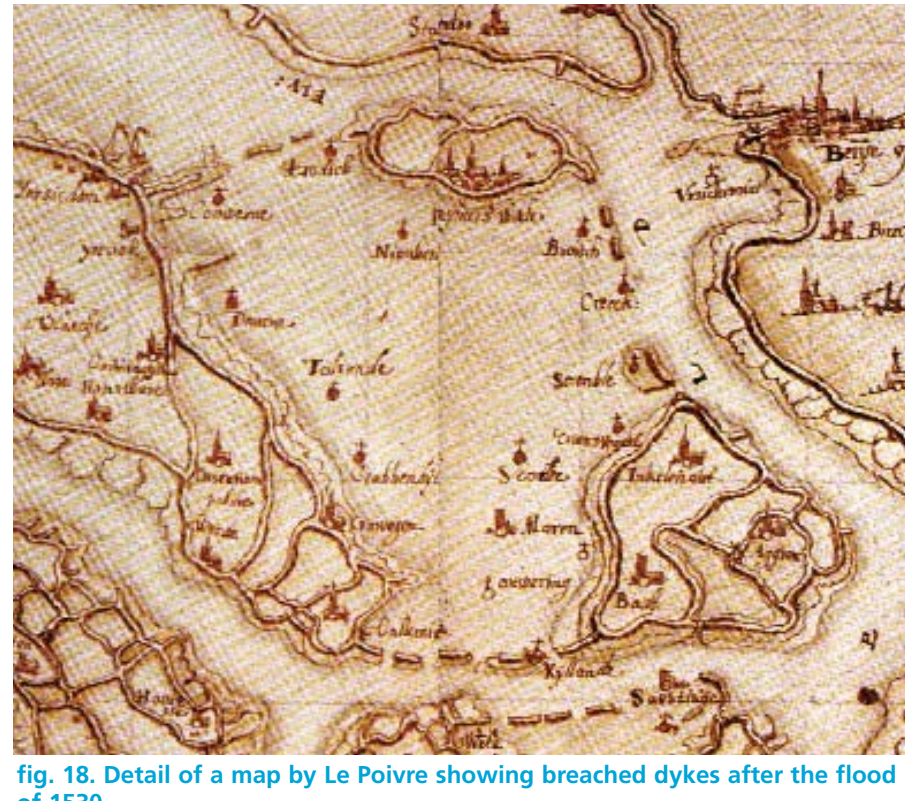

fig. 18.
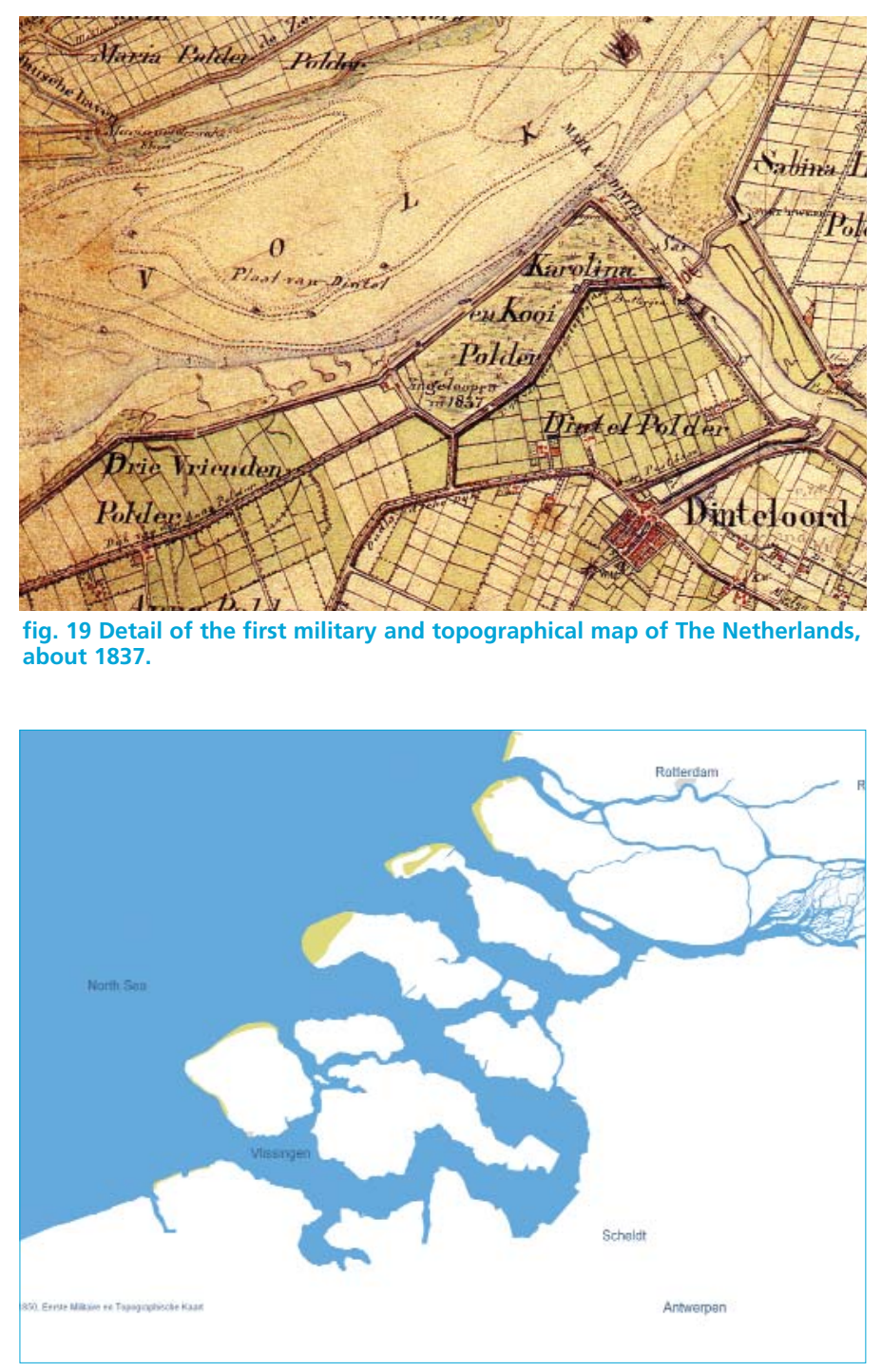

fig. 20 The estuary in 1837 


\section{The disaster of February 1953}

During the night of 31st of January to 1st of February 1953 , a spring tide occurred in the North Sea. Together with a powerful storm in exactly the right direction, a huge wave of water was driven towards the south. Water levels at sea rose more then $250 \mathrm{~m}$ above normal. At the coasts, the waves were even higher. On 31st of January 1953 at $15.00 \mathrm{~h}$, the banks of the river Tees, in north-eastern England, started to flood at the coast. As the wave travelled southwards, dams and dykes broke and the land behind was flooded over a distance of more than $300 \mathrm{~km}$. Nine hours later, at 00.30 , the Thames estuary was reached. In total, 10,000 ha was inundated and 350 people lost their lives.

The flood peak reached the Dutch coast during the night of 1st of February. At $03.24 \mathrm{~h}$ it reached its highest point at Vlissingen, where it was $4.55 \mathrm{~m}$ above Main Sea Level. The dykes broke in more than 90 places, more than 130,000 ha were flooded and 1836 people died. In Flanders relatively few hectares were flooded, and there were 'only' 5 deaths. The timing of the flood, of course, could not have been predicted. The dangerous situation, however, was well known. By chance, a report "Nota der Afsluitingsplannen der Tussenwateren" (On the Closure of the Estuarine Branches) was presented by the National Water Board two days before the disaster, indicating that the Board was well aware of the dangerous situation. The first plans for improving safety in the estuary had already been drawn up before the war. The war itself, and reconstruction for years afterwards, prevented the implementation of any plan in the delta.

fig. 21 The flood of 1953 in the southern part of the North Sea

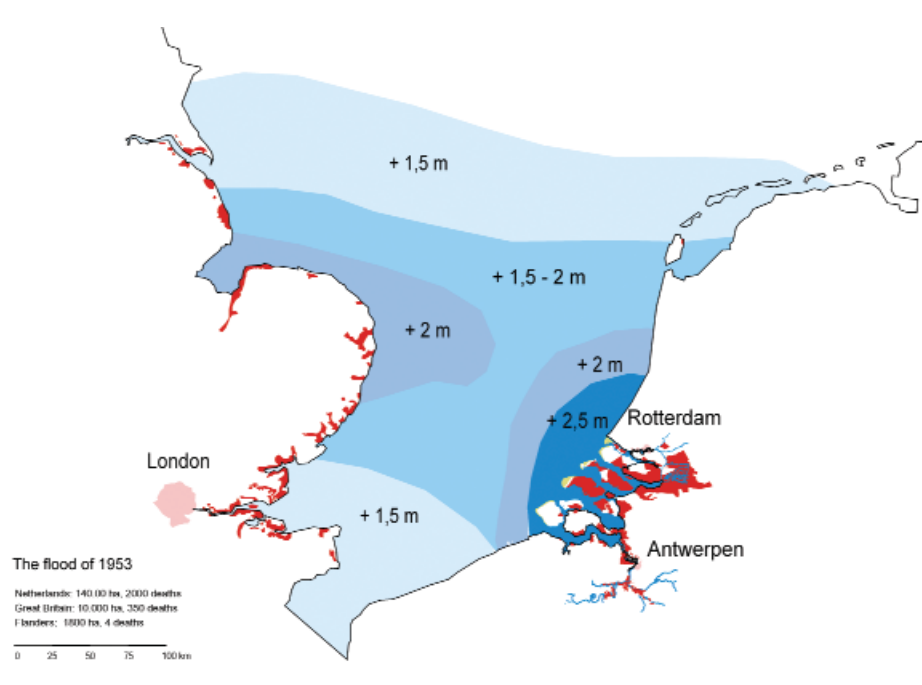

In February 1953 a Delta Commission was appointed and, one year later, came the recommendation to close all the estuarine branches except for two: the harbours of Rotterdam and Antwerp were to remain 16 Changing estuaries, changing views

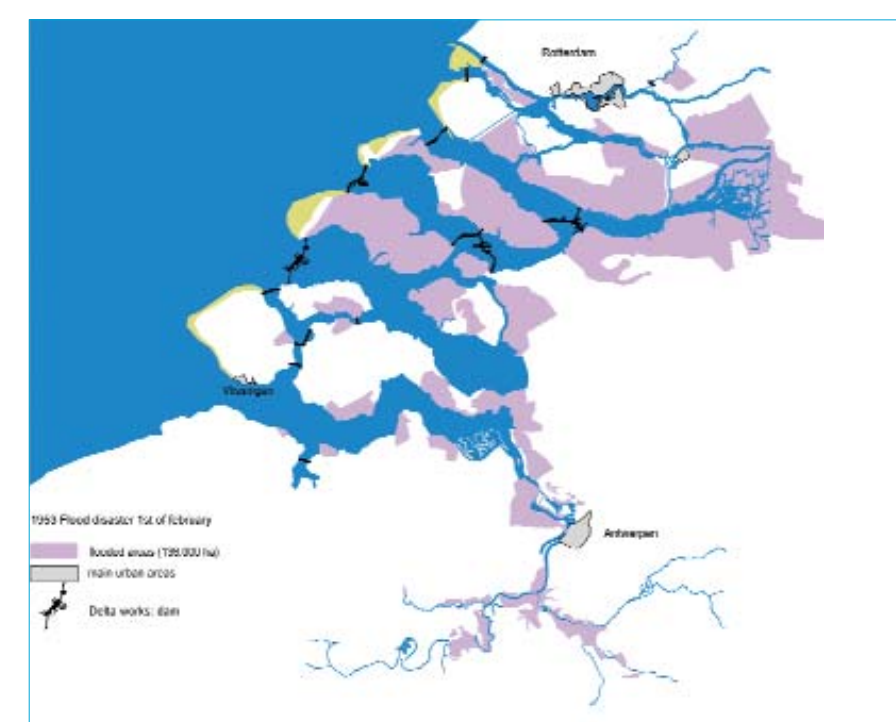

fig. 22 Flooded areas in 1953 and the answer: large dams

open to the sea for the passage of large ships. After some years of preparation, the works started in 1958 and lasted until 1989. In England, the great mobile Thames Barrier was built to protect London. In Rotterdam, a movable barrier was built in the ship canal which links the sea to the inner harbour. The Flemish region was flooded again in 1976 but proposed a different approach.

\section{The Dutch "Deltawerken" or Delta Works}

\section{8 - 1986}

Nieuwe Maas / Nieuwe Waterweg

(fig. 24 and fig. 53)

About 1960, the expansion of Rotterdam Harbour started to move towards the sea. A new port was built on an artificial peninsula projecting from the coast. In combination with these works, the estuarine branch was closed off from the sea. Only one shipping route was left open between Rotterdam and the sea.

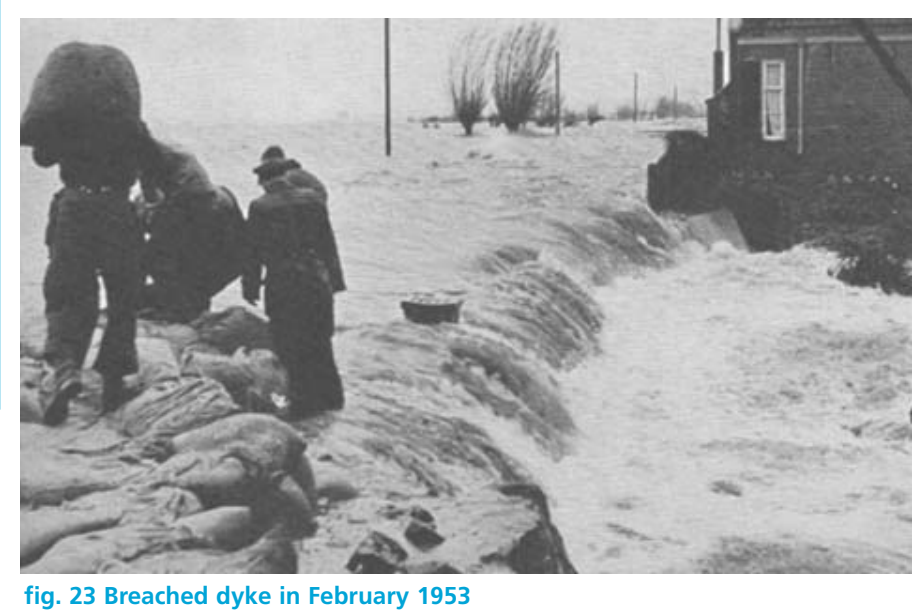

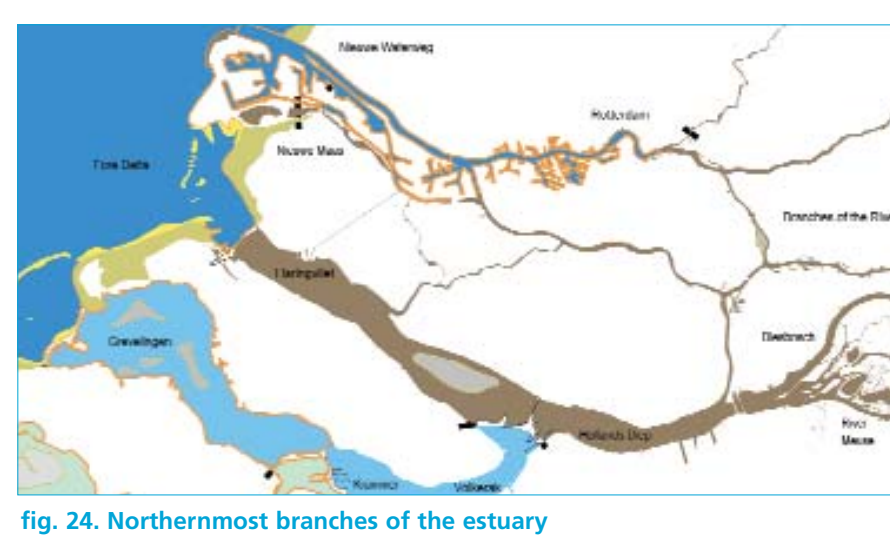

Biesbosch / Hollands Diep / Haringvliet The second estuarine branch was closed off from the sea in 1971. The dam was equipped with large sluices. Through these northernmost branches, the rivers Rhine and Meuse flow into the sea. In times of low discharge, the Haringvliet sluices are closed and all river water is directed through Rotterdam harbour to prevent salt water penetrating eastwards. In times of high discharge, the Haringvliet sluices are opened. These branches are essentially freshwater areas. A short salt/brackish/freshwater gradient exists in the harbour of Rotterdam. Whenever the Haringvliet sluices are open, a sudden transition from freshwater to saltwater occurs. Agriculture on both sides of the Haringvliet is allowed to use the fresh water. The tide in the two branches has been reduced dramatically. The closure of the Haringvliet occurred in a period of maximal pollution of the Rhine River. Polluted silt has collected in the deeps of the former estuarine branch on a very large scale. In recent years, new layers of lower sediments.

It took the river Rhine River about 400 years to fill the area inundated in 1421 with sand and silt, thereby turning it into the Biesbosch. The river will go on bringing sediment to the Hollands Diep / Haringvliet over the next few centuries.

Krammer-Volkerak / Grevelingen

The third branch of the estuary was cut of from the sea by a dam and, further inland, a second dam

divides the branch into two distinct compartments. The eastern one, the Krammer-Volkerak, is filled with fresh water and, apart from some small streams, is fed only by rain water. No polluted water from the Rhine is allowed to enter. The westernmost part, Lak
Grevelingen, has brackish water without connection to the sea.

Eastern Scheld

(fig. 25 and fig. 53)

Over the 30 years it took to complete the works, the impacts gradually became visible and values in society changed. Environmentalists argued that the closure of the branches was disastrous for nature. Fishermen found that their interests had been forgotten altogether. The rich fishing grounds of the estuary and the banks of oysters and mussels, were disappearing fast. The two groups found common cause and were successful in changing the plans for the fourth branch, the Eastern Scheld

(Oosterschelde). Instead of a closed dam a permeable dam was constructed, allowing two-thirds of the tida volume to pass through. Only in times of severe storm is the dam closed (see front cover).

The waters of this branch remain salty, and a reduced tide is still present. The costs of this one permeable dam were enormous: about 3.5 billion euro, that is twice as much as the works on all the other branches together. National pride on either side of the English channel led the Dutch and the English to claim separately that their dam and their Thames Barrie was the Eighth Wonder of the World

\section{Western Scheldt}

The Western Scheldt, remained open. One secondary branch was closed and the dykes were reinforced. To accommodate the passage of ever bigger ships into the harbour of Antwerp, the Western Scheldt has to be dredged continuously. Shallow places are deepened and deep places are filled. In the eastern part of the estuary, a canal was built to connect the harbours of Rotterdam and Antwerp.

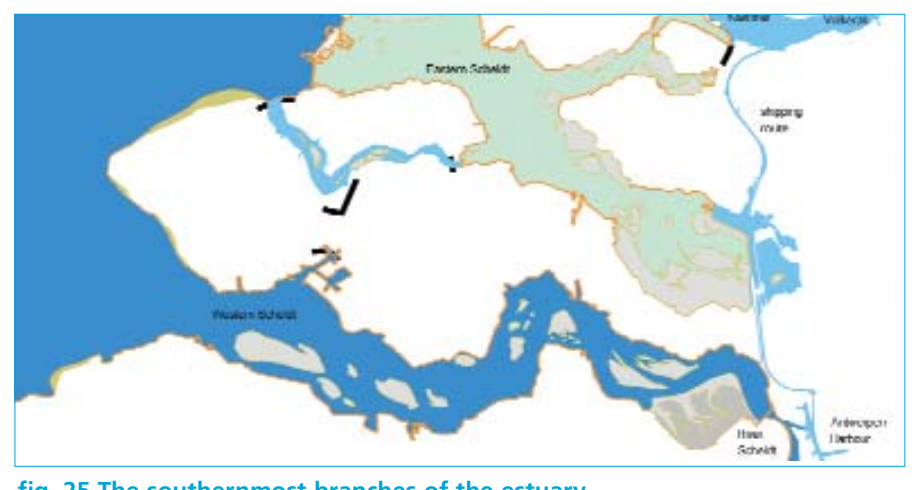

fig. 25 The sout 


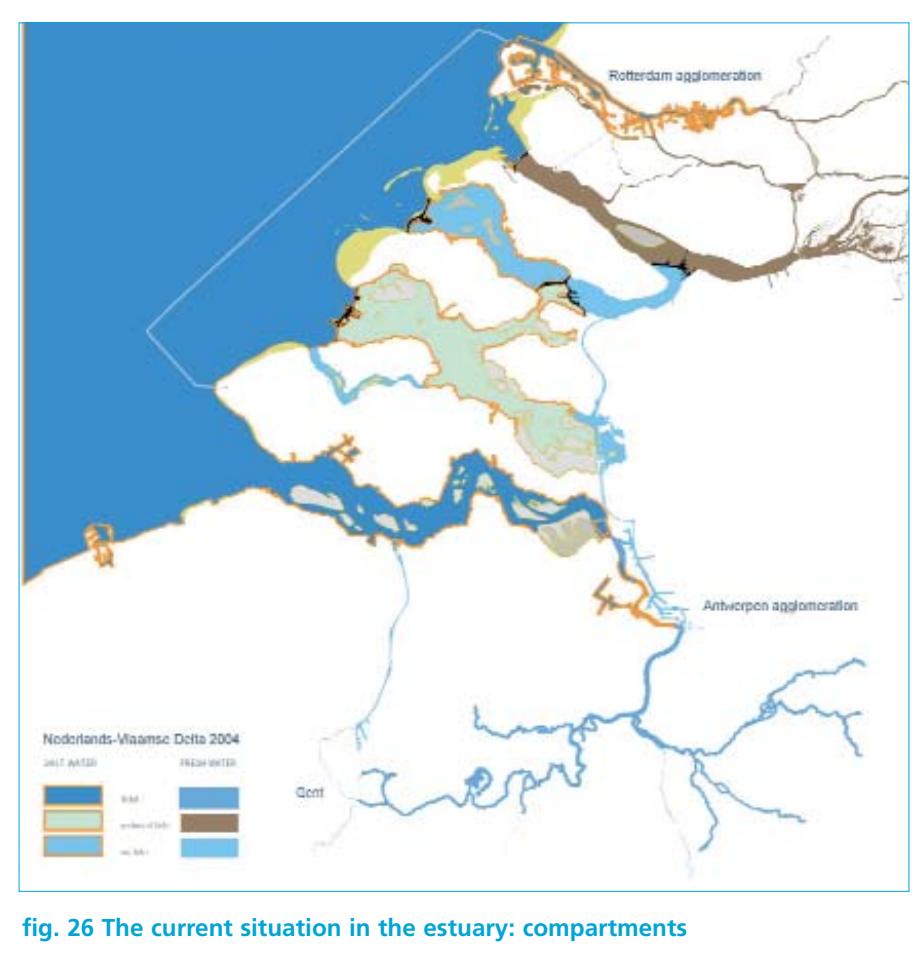

\section{Current morphological situation}

The situation in the delta now, from a morphological point of view, can be summarised as follows:

The transition zone between rivers and the sea has disappeared in most places.

Sculpting of the landscape by the tide has been reduced or is absent altogether.

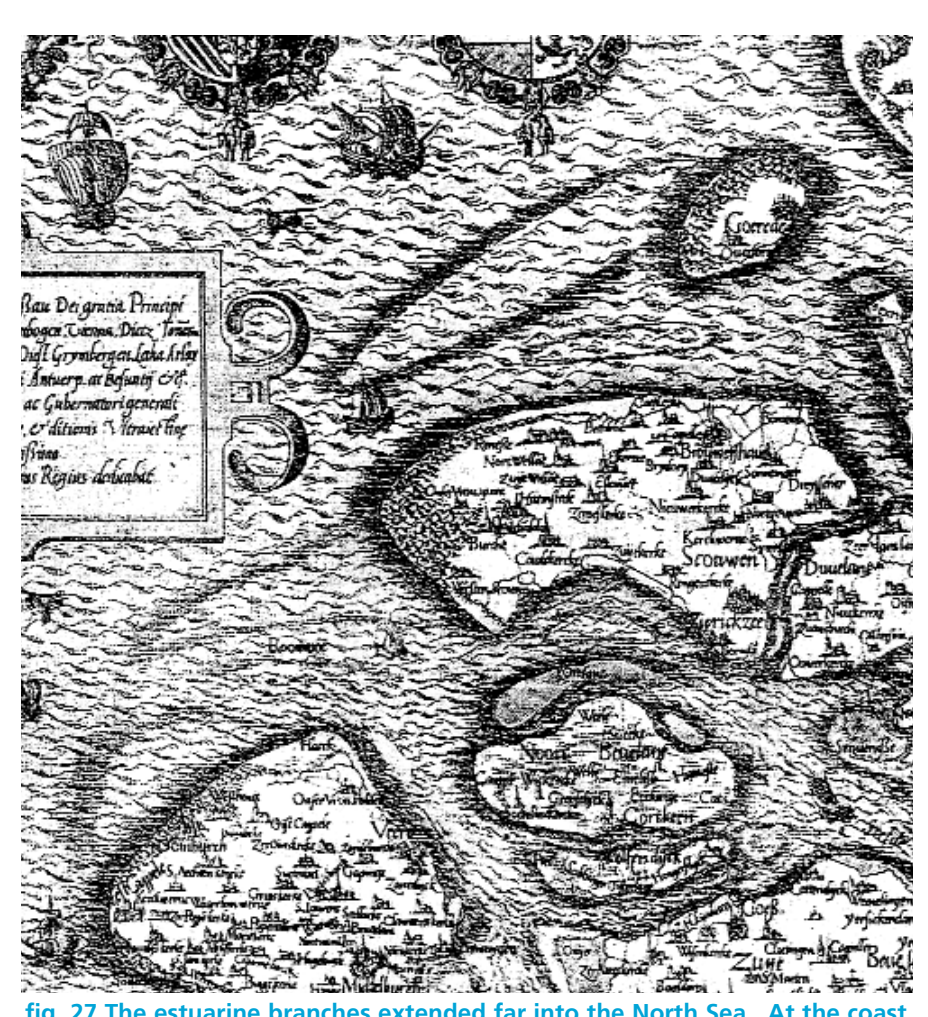

fig. 27 The estuarine branches extended far into the North Sea. At the coo
there was an extensive area of gullies and sandbanks, In this figure, the

situation in 1560 is shown as presented by

18 changing estuaries, changing views
Sedimentation processes which, in the period between AD 1000 - 2000, guaranteed that sea-level rise was accompanied by increases in the height of the land, have stopped.

In the areas with reduced tide, resulting in new volumes and forces, the dimensions of the banks and reeks are changing.

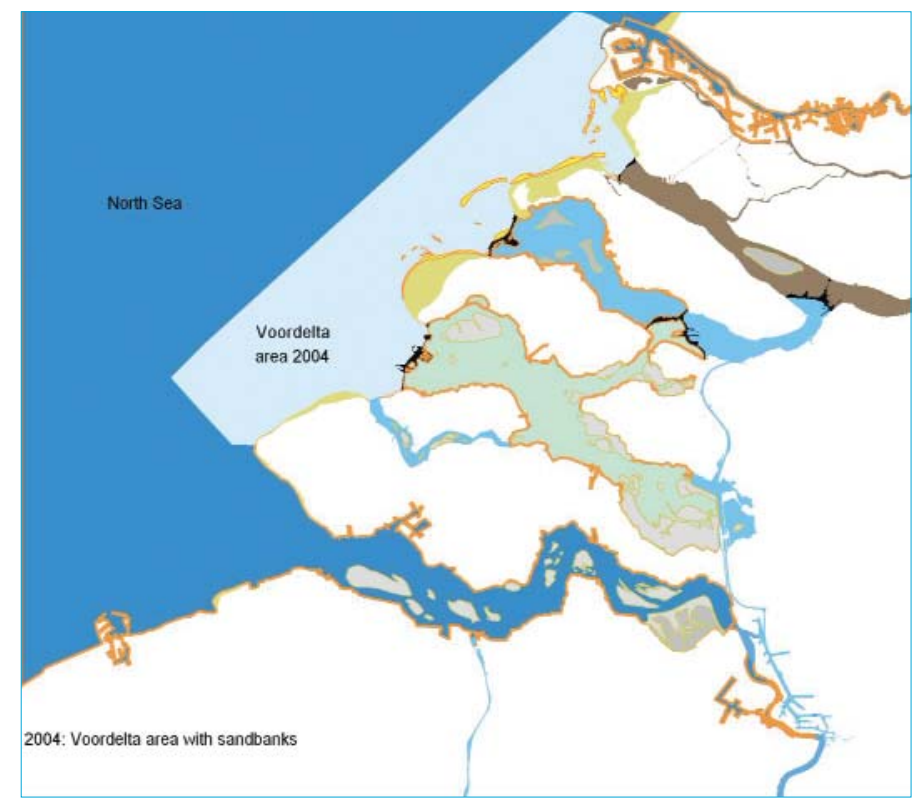

fig. 28 After closing the branches, the sea started to rearrange the
sand masses along the coast. New sandbanks developed. This "voor

(fore-delta) is considered to be very natural and almost no activities are
(allowed. No-one knows, or is able to calculate, the outco ace of this process.

in the areas with a constant water level (salt or fresh) slands are disappearing in the absence of the organising forces of the tide.

In the remaining open branch, the Western scheldt, the ratio between the elements of the tidal system are changing: more deep water, a few high areas and an alarming reduction of all intermediate conditions.

Gradients between freshwater and saltwater are absent or abrupt.

Even in the Eastern Scheldt, where so much money has been spent to keep it open, the very essentials of an estuary are absent. Here, the influence of the sea, the tide, is kept alive but the connection to the river has been lost. From the point of view of its function as the transition zone between river and sea, the Eastern scheldt is only half an estuary.

The absence of nutrients from the river and the exchange of life forms between river and sea systems, shows that this branch is becoming poor in nutrients. Estuarian life is disappearing and it fulfils no function
for the river.

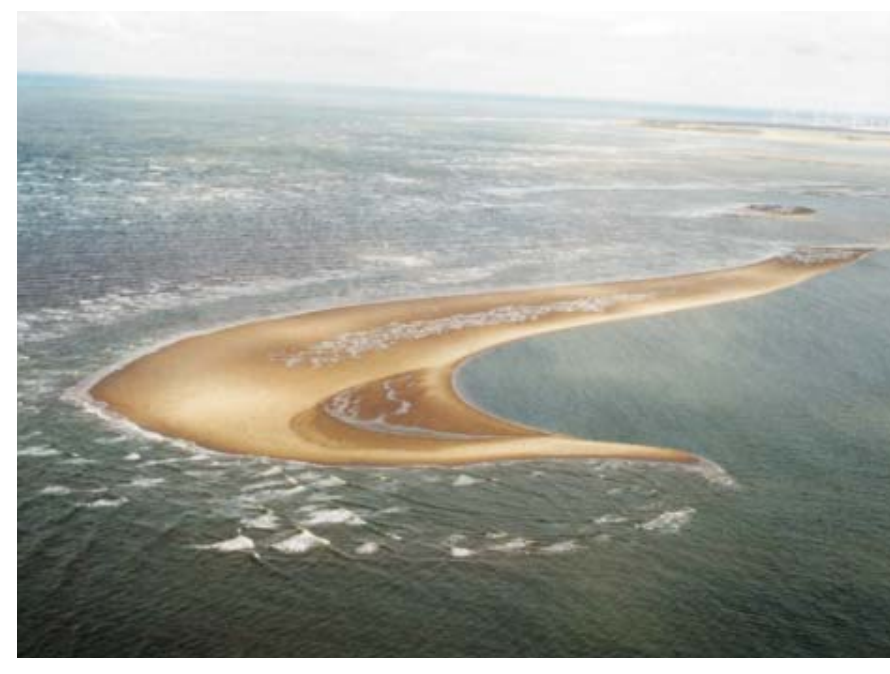

So, closing an estuary costs more than money alone. The price of "safety" through dam construction is a mutilated natural system and, ironically, a growing risk from floods.

In the meantime, the filling of the Haringvliet by sediments from a clean Rhine River promises a rich sedimentation process that will last for centuries. The most promising phenomenon is the formation of a new system of sandbanks in front of the closed dams. There, the changes in the tidal system are rearranging the sandbanks in such a way that a new, shallow, sandy coastal sea is forming with sandbanks and creeks. In the Haringvliet area, a natural mouth of the Rhine River is even developing, complete with salt/fresh gradients. In the meantime, numerous discussions are underway about mitigating the

fig. 29 The fore-delta: new sandbanks are emerging in new patterns. 


\section{Ecology: where river and sea meet}

3.1 The physical and ecological processes of an estuary

This chapter describes the physical processes and related ecology of the aquatic and intertidal environment of a brackish estuary. The basic physical (salinity and turbidity) and chemical (nutrients) parameters of estuarine systems show that, in
general, they are very productive although supporting a relatively low number of species. Of these species, however, several depend on the estuary as a migratory zone.

\section{Nutrients and turbidity}

In most estuaries, nutrient input from the sea is low in comparison to that from rivers. Nutrients carried to the estuary by the river, depending on the discharge cause a spatial gradient between the river and the sea. Besides nutrients, rivers transport fresh-water species. These plants and animals die off when they enter the brackish water zone, supplying even more nutrients to the area. It could be said that the river dies in the arms of the sea, providing large amounts of food for the organisms adapted to the brackish conditions. While this plentiful food supply is are zoobenthos eaters feeding on the rich invertebrate communities'

Estuaries are full of movement (tides, currents), by suspended aggregates (mud) in the water column.

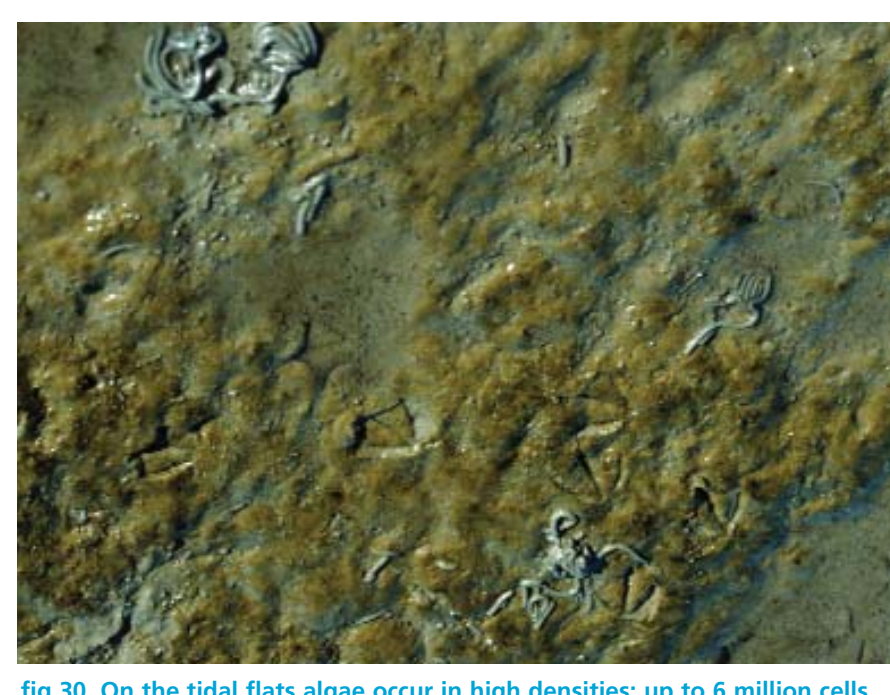
available for the higher organisms, most of the birds which results in turbidity. Turbidity is primarily caused

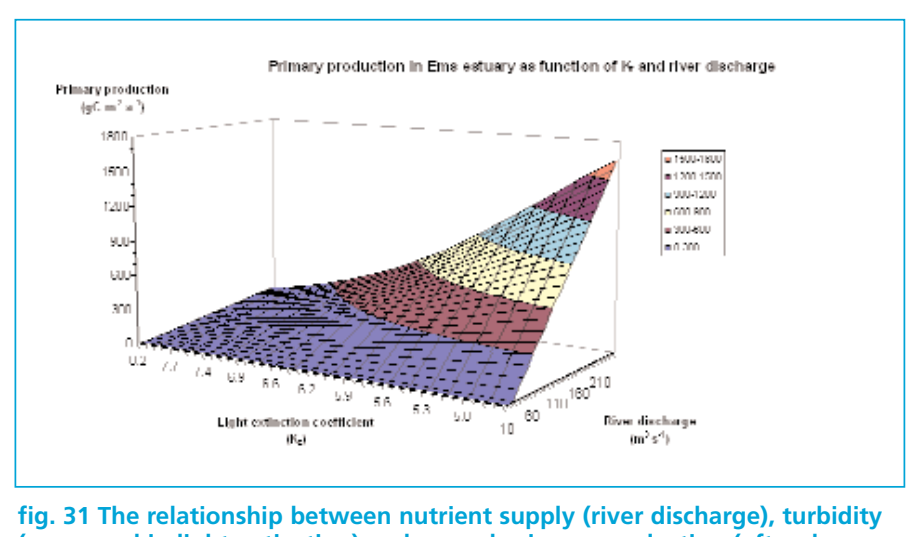

fig. 31 The re
Jongessed in 2000 )

mainly inorganic material (e.g. clay). When millions of particles are suspended in the water, little light can enter. Although estuaries have high nutrient concentrations, in conditions of high turbidity and therefore low light penetration, there is little opportunity for production of autotrophic algae and macrophytes. Nevertheless, adapted aquatic animals (heterotrophes) can exploit the conditions very effectively.

Turbidity is reduced in the lower part of the estuary and at its maximum at the head of it due to available mud accumulation processes. Local oyster and musse banks can decrease turbidity by filtering the suspended biological components out of the water. The natural turbidity gradient in an estuary is mirrored by a gradation in primary production potential because algae production in these areas is usually light limited. In general this means that the lower the turbidity, the higher the production as long as there is a fresh water supply (enriched with nutrients) to the area (fig. 31). The gradient in turbidity and nutrient availability in an estuary contributes to the system's diversity and is one of the characteristic features of estuarine systems.

In the intertidal zone salt marshes occur. These can be considered as a temporal deposit of fine sediments and organic material which contributes to a decrease in turbidity. In the floor of a salt marsh, the

degradation of the deposited organic material and

subsequent transformation of nutrients, leads to local nutrient enrichment which in turn increases the

primary production potential. In this way, a salt marsh functions as a natural sewage treatment installation. Salt marshes represent an important natural habitat and landscape element and play a role in the life cycle of several aquatic organisms (fishes and
invertebrates) and birds'. fig 30 . On the tidal flats
on a square centimeter. 


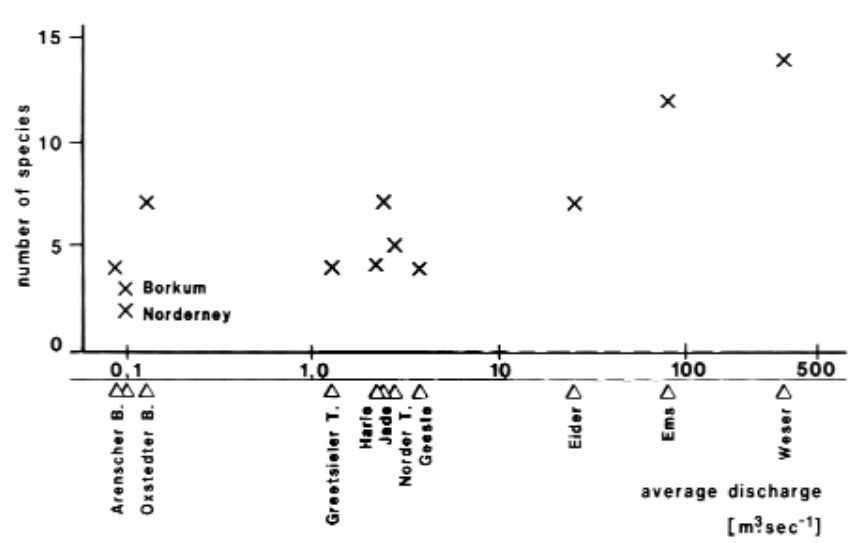

fig. 32 The number of brackish water species in relation to the average
freshwater discharge (volume) of estuaries and outlets (after Michaelis et$$
\begin{aligned}
& \text { freshwate } \\
& \text { al., 19922 }
\end{aligned}
$$

\section{Salinity}

A full salinity gradient is of great importance to the flora and fauna of an estuary. Although rather high or very low salinity may be the best condition from the species diversity point of view, the zone with intermediate salinity ranges is very important in the life cycle of several salt- and freshwater species. They use this zone for spawning, for juvenile phases or as transmigration zone between fresh water and the sea. Many marine plant species benefit from freshwater influences in the marine habitat for the germination and settling of seedlings ${ }^{3}$. Figure 32 shows the relationship between discharged fresh water and species composition in estuaries. The number of intertidal macro zoobenthos species are presented as a function of the freshwater discharge into the coastal sea. Implicitly, the figure relates the extent of the estuarine zone to the species composition.

\section{The estuary as a transit area}

Estuaries can be considered as transit areas: many species pass through but few of them stay in the turbulent conditions. Nevertheless, many species need the estuarine system to survive. Besides the connection between sea and rivers, an estuary provides breeding and hiding places for the fauna in shallow parts and near the vegetation-covered banks.

In a properly functioning system, the gradient between fresh water and salt water is gradual and unobstructed. Diadromic fish profit from this situation living part of their life cycle in sea water and part of it in fresh water (e.g. while spawning)4.
Fish that pass from the river to the sea or vice versa, rest in the estuary in order to gradually adapt their species lay their eggs in this transit area: the fish not suffer from salt stress, which would happen if they were laid in sea water but for the newly born fish, their natural habitat, the sea, is nearby.

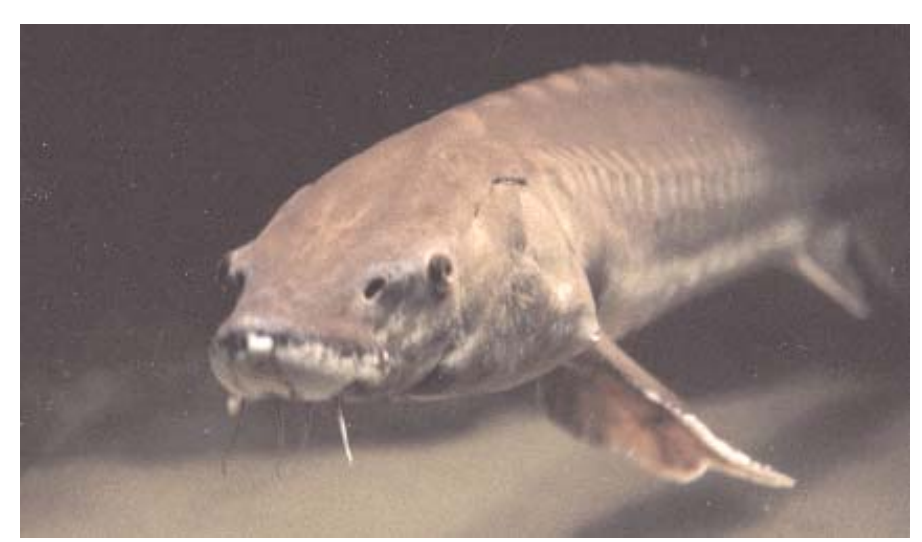

fig. 33 In the past, the sturgeon, Acipencer sturio, matured in the Rhine
Meuse and Scheldt estuary

3.2 Impact of the Delta Works

In earlier days, huge areas were available for natural processes in the Dutch south-western estuary. During a millenium of land reclamation, the higher parts of the system were removed while the lower parts became deeper (Chapter 2). These early alteration already had a huge impact on the ecology by eliminating typical habitat types. Moreover, they led to the construction of the Delta Works which added further stresses to the ecology of the system.

The consequences of the engineering works for the biota will be described here by reference to the main abiotic changes in turbidity, nutrients and salinity. In addition, the two major problems of pollution and connectivity will be discussed.

\section{Nutrients and turbidity}

Following construction of the Delta Works, most of the estuary was blocked from the influence of the se and the rivers. When tidal influences disappear, the velocity of the water current declines, suspended matter sinks and the water becomes clear. Thus the characteristics of the Dutch south-western estuary system changed: the unique estuarine situation as described in $\$ 3.1$ was destroyed.

When the nutrient component is high but turbidity has declined, algal blooms easily occur. Thus one negative aspect of eutrophication in the river mouth was the replacement of eelgrasses by green algae ${ }^{5}$.
Accumulation of the algae caused a noxious smell and the death of benthic animals due to

deoxygenation of the soil. On the other hand, when algal blooming did not occur, water vegetation very quickly blanketed the system. While many birds related to the tidal regime departed because of these conditions, the numbers of bird species feeding on conditions, the numbers of bird species feeding increased.

\section{Salinity}

As explained in §3.1, the changing salt concentration of the water bodies has had a critical influence on the aquatic communities. Following desalination, the typical vegetation of salt systems was replaced by
more salt-averse species ${ }^{6}$. Salt water plants and animals died just after the exclusion of the salt water, leaving anoxic conditions in the deeper parts of the lake. The recent decline of eelgrass stands in Lake Grevelingen and the Eastern Scheldt is related to the high salinities that arises from the further reduction of freshwater input from local sources.

The same happened to the macro-invertebrate community. Shrimps and crabs disappeared and species such as the Zebra mussel', which prefer stagnant, fresh water, filled the gap that was created. In the fish community, too, severe changes were observed $^{8}$.

After the construction works, the vegetation on the banks changed rapidly: salt-avoiding plant species colonised the desalinising areas. The once-typical estuarine system became covered with typical 'inland' species ${ }^{9}$. The rough vegetation and bushes that

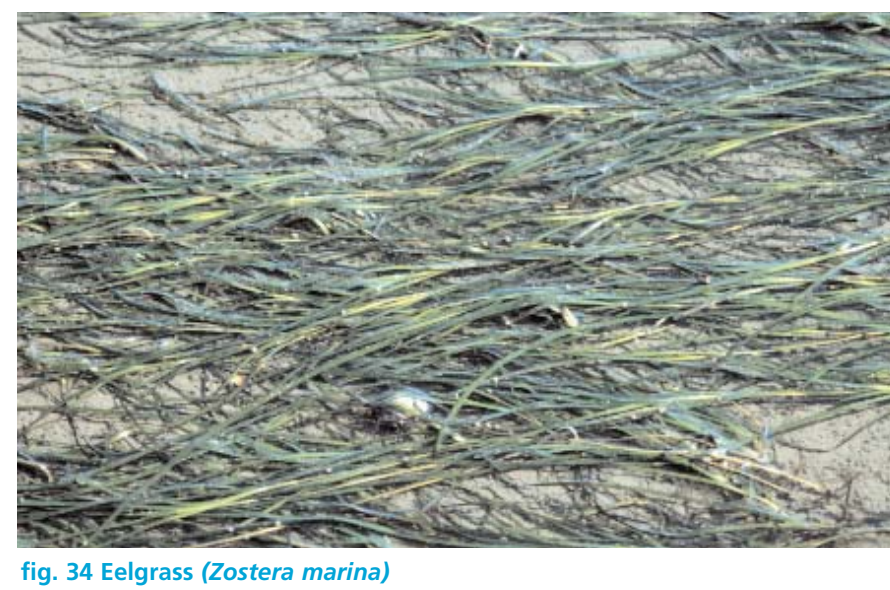

developed on the banks provided opportunities for bird species which are not strictly related to the delta $^{10}$

Besides desalination, the disappearance of the tida regime and thus the lack of hydromorphological renes caused erosion by wind-driven waves; the natural sedimentation process was thereby stopped.

\section{Pollution}

The most important outlet of the rivers Rhine and Meuse, the Haringvliet, was closed off by a sluice complex in 1970. Although an increase in sedimentation was expected as a result of this intervention, the large quantity of material that
settled in the Dutch delta became the chemical for the Rhine and the Meuse rivers. More than 150 million $\mathrm{m}^{3}$ of highly polluted sludge have settled here. Fortunately, the consequences are restricted to the Haringvliet and Hollands Diep; thanks to the construction of the compartments, pollution of the whole south-western estuary was avoided. The building of the Volkerakdam (1969) excluded the polluted Rhine and Meuse water from the rest of the delta, while the construction of the Kreekrakdam (1867) kept the polluted Scheldt water out.

However, the quantity of pollutants in river water has steeply declined in recent decades. The toxic substratum is being covered with relatively clean sediment, minimising the possible influence on the ecosystem and biota.

\section{Connectivity}

Connectivity is the unhampered passage of water, substratum and biota between different systems. While the dams kept pollution out of the delta, they hindered the regular refreshment of the lakes and eliminated connectivity. Since the connection between fresh water and sea water has been blocked, full development of brackish water zone habitats, including mud flats, sand flats, channels and salt marshes, is hindered. Moreover, the large engineering works prevent the passage of fish between the se and the river, where they spawn. The removal of transition zones between the river and the sea is seen as an important cause of the decline of many diadromic fish species in The Netherlands (fig. 35).

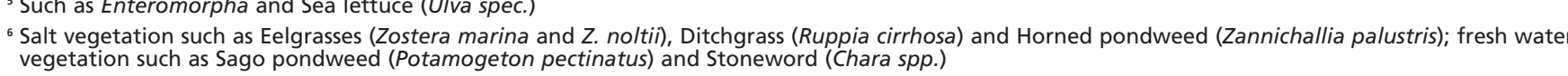
'Dreissena polymorpha

- Species such as Plaice (Pleunectus platessa) declined and Pike-perch (Lucioperca), Minnow (Cyprinidae) and Roach (Rutilus rutilus) appeared.

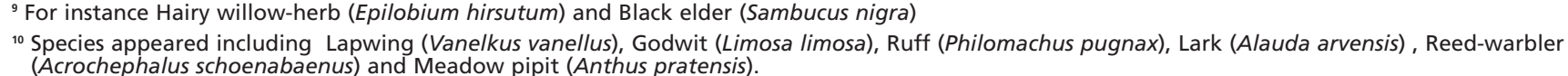




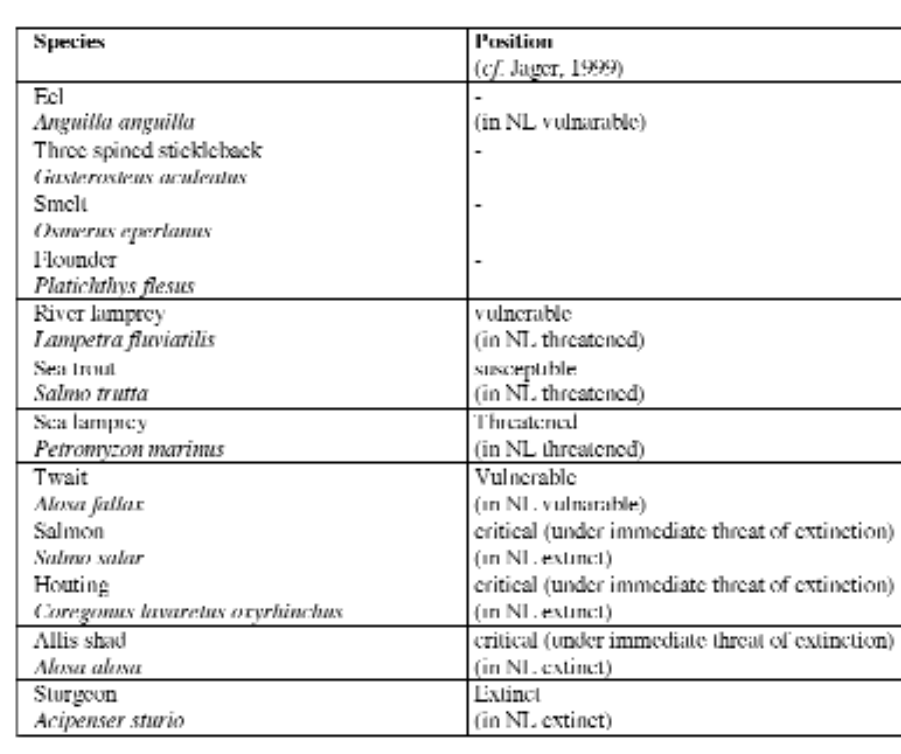

fig. 35 Diadrom mus fish species: common species and species extinct of
under threat in the Netherands (Jager, 1999 )

The vulnerable system of the salt marshes became seriously threatened by the changes. The total surface of intertidal areas had already been greatly reduced by land reclamation but the steepest recorded decline of salt marshes was due to the delta engineering works (1960-1986, see fig. 37). The connection constructed between the Scheldt and the Rhine also contributed to the decline (1987). The figure shows an increase in salt marsh in the 1920s and 1930s; this is a result of the introduction of Common cord-grass", planted for the reclamation of land. These artificial salt marshes are only temporary meant to disappear again when sedimentation has raised the land high enough for agricultural purposes.

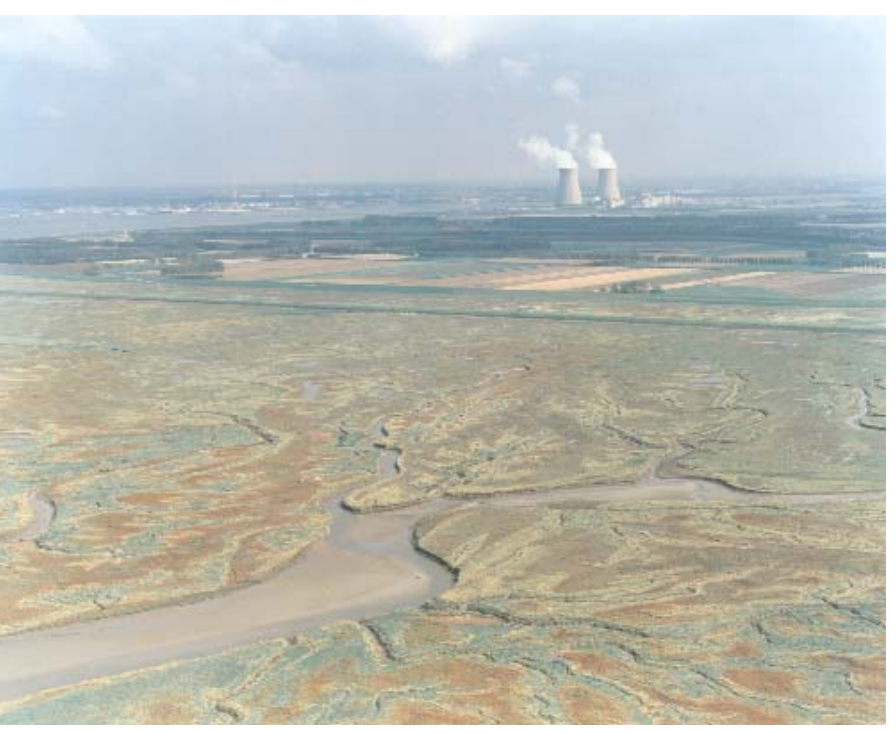

" Spartina anglica

24 Changing estuaries, changing views
3.3 Evolution of the newly

$$
\text { created systems }
$$

Following construction of the Delta Works, severa branches were turned into fresh or brackish lakes, the 'compartments'. When the negative consequences of this compartmentalisation became clear efforts were made to minimise them: Lake Grevelingen was turned back into a saltwater body, and one branch remained a semi-open connection to the sea, the Eastern Scheldt (see \$5.2). The Western Scheldt was not closed off at all although it was affected by other developments. Each of the compartments developed differently, as is discussed in this section (see figs 24 and 25).

3.3.1 The isolated lakes: compartments

The compartments were created to keep the water bodies under control (see §2.4). The changes in turbidity, nutrient concentrations and salinity described in 3.2, are most clearly seen in these 'lakes'. The south-western estuaries changed into a set of man-made basins (fig. 26), each becoming susceptible to eutrophication. Lakes Volkerak and Zoommeer suffer from severe algal blooms caused by phosphate in discharges from western Brabant which accumulate in the groundwater. A suggested way to minimise the problem is to flush the lakes with a sufficient amount of fresh water to reduce the artificially increased residence time of the eutrophicated water in the lake (see §3.2). When algal blooms do not occur, the changed light regime offers opportunities for plants. Initially, some of the lakes (e.g. Volkerak) had an enormous increase in aquatic vegetation which has since changed through succession processes.

Pollution problems are also most clearly observed in the compartments, especially in the severely affected Hollands Diep and Haringvliet (§3.2)

All the compartments are affected by interrupted connectivity. migratory fish species are rarely found now. Although the number of species living in the Haringvliet actually increased after the enclosure, they are mostly generalist (riverine) species, untypica of estuarine conditions.

The ecosystem of Lake Grevelingen has endured several changes. The sea branch was first cut off on the east side blocking the supply of fresh river water and increasing salinity (1965). Then, in 1971, th second dam further obstructed the connection to the sea; the stagnant system started to desalinise under the influence of rain water and the discharge regime the sluice. The system continues as a salt lake thanks to the sluice in the Brouwersdam (1978) that

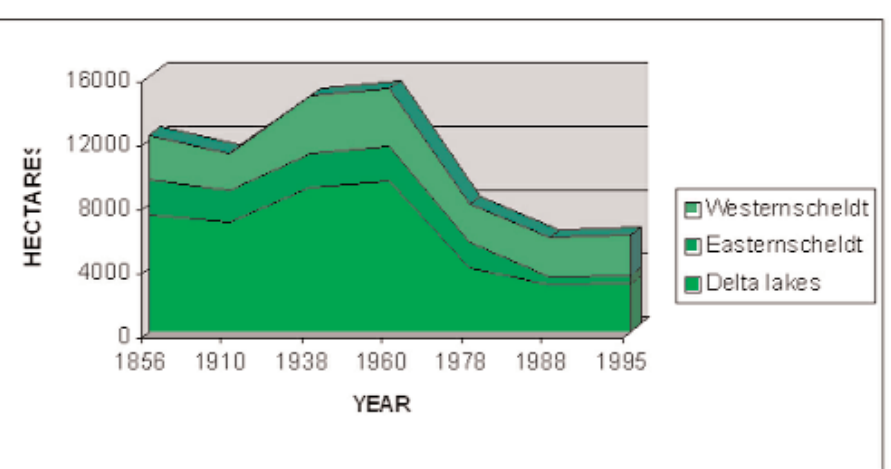

fig. 37 Development of the
estuary of The Netherlands

connects the lake with the North Sea. This was an attempt to minimise the problems that occur in the compartments in genera.

The ground surrounding Lake Grevelingen desalinates more slowly that around the other constructed lakes because of different soil composition and incidental flooding with salt lake water instead of fresh water. The difference in development compared to the other other (freshwater and brackish) lakes is found in the succession: on the lower parts salt species were not replaced by salt-averse species ${ }^{2}$.

Besides the brackish zone discussed above, The Netherlands hosts the largest freshwater tidal area in Europe: the Biesbosch. Although it is further away from the enclosures, this unique system was also affected. The ecologically valuable freshwater areas are not tidal anymore and have declined due to the erosive power of wind and waves. The absence of the tidal regime means that these areas are no longer regularly flooded which has caused the disappearanc of the (substrate binding) vegetation and stopped natural sedimentation.

3.3.2 The semi-open branch: the Eastern Scheldt

Although the Eastern Scheldt is still connected to the sea, the storm-surge barrier does affect the ecology. Near the locks, the stream velocity has strongly

increased while further east it has decreased. As less sea water is able to enter the system, the influence of the sea in the Eastern Scheldt has declined and heavy flooding no longer occurs.

Since the influence of river water has been cut off the Eastern Scheldt has also become a 'compartmen As a result of the lack of river water, the input of nutrients to the system is low. Therefore, despite the changed light regime created by the decreased turbidity, primary production is also low.

Due to the Delta Works the sedimentation process in the sea-connected estuary has ceased and erosion has become dominant causing a reduction in the size of the intertidal area (fig. 37). Sand transport is strongly correlated with the velocity of the current. Since the hydromorphological dynamics were altered by the storm-surge barrier and the two inland compartmentalisation dams, less sediment is entering the Eastern Scheldt. This results in an increased uptake of sediment from the river banks and the river bed. This phenomenon is to referred to as the so called "sand-hunger" of the water system (fig-37).

This process still continues. Apart from the direct effect described above, an indirect response has occurred. The tidal range has decreased by $13 \%$ and, as a result, the cross links between the tidal channels have gradually been obliterated. Eroded sediment from the mud flats and shoals now generally settles in the main channels instead of being redistributed. The salt marshes experience more erosion and less sedimentation which results in a loss of $0.6 \%$ of the total marsh area each year. The Eastern Scheldt will gradually evolve towards a new morphological balance with considerably less or, in the end, no tida land at all.

Mussel banks are not doing well under the changed circumstances. The exact cause is still uncertain, but 'sand hunger' and low primary production are very probably contributing factors. The eelgrass

population has declined in the Eastern Scheldt, as it did in the closed- off systems, probably because of reduced local freshwater inputs. For the zoobenthic and herbivorous bird populations, less food is available as a result of the changed situation.

\subsubsection{The open branch}

the Western Scheldt

The Western Scheldt was not directly affected by the construction of the Delta Works; the saltwaterfreshwater gradient is still intact, and so is the tida regime. Other human activities have however affected it (see Chapter 2). Thanks to the building of dykes and to land reclamation, the water in this branch does not have enough space to dissipate its (tidal) energy. As a result, it is deepening, intensified further by dredging. The salt tongue thus penetrates further up the river Scheldt, moving the transition zone upstream. High river discharge peaks cause
regular die-off of salt water species. Since 1800, the 


\section{Socio-economic developments}

area of banks and shallow zones has severely declined offering less habitat for many species, in particular the wading birds.

The dynamics of the Western Scheldt are, at least partly, still present. They are the basis for a varied salt marsh structure on the scale of the estuary. Up to now there is no clear idea about the area of salt marsh that will eventually survive in the Western Scheldt. Relocation of the dykes, giving more space to the estuary and thus restoring the tidal volume, appears to be the most effective measure to increase the extent and diversity of the salt marshes (see \$7.2). Despite the decline of intertidal areas, vast numbers of waterfowl visit the Western Scheldt; approximately one million birds are counted yearly. Thirty-eight species exceed the $1 \%$ value of the Ramsar
Convention ${ }^{13}$. This means that more than $1 \%$ of the fly-way population of those species remains at specific moment on or close to the salt marshes.

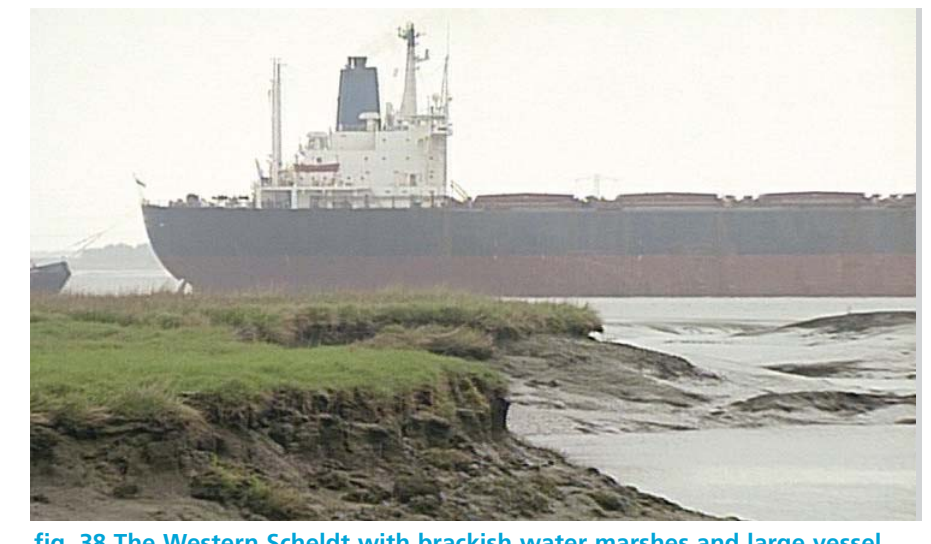

The design and implementation of large engineering projects partly depends on cultural, economic and social factors. After the 1953 disaster, two options were available: to change land use, or to intervene in the natural system. The people, and politics, decided it would be the latter. To understand how, the social and economic structures of the affected populations are discussed here; the political aspects are described in Chapter 5. The first part of this chapter addresses use of the land, the second part describes the economic aspects.

\subsection{Use of the delta resources}

A prerequisite for the survival of all species is territory. This includes human beings who appear to have an instinctive wish to enlarge their habitat. The main biological reason can be found in food supply. For humans the main socio-economic reason is achieving independence and accumulating wealth. Food is produced by agriculture and harvested from the sea; wealth through trade, industry and investments. It explains why the people in The Netherlands worked so hard to reclaim land from the sea for housing and industry, but mainly, in the past, for farming.

4.1.1 Use of the wealth of the sea:

$$
\text { fishery }
$$

Where sea and rivers meet, the natural production in the creeks and on the silt- and sandbanks is very high (§3.1). People started to exploit these riches through fishing and the gathering of mussels and oysters. Although the area was very suitable for fishing (twothirds of the province of Zeeland consists of water and only one-third is land), in recent times this has not been a large industry. Around 1900, 1\% of the working population worked in the fisheries, about 850 people. Nowadays this figure is almost the same (900), although the total number of inhabitants and jobs in the region has doubled.

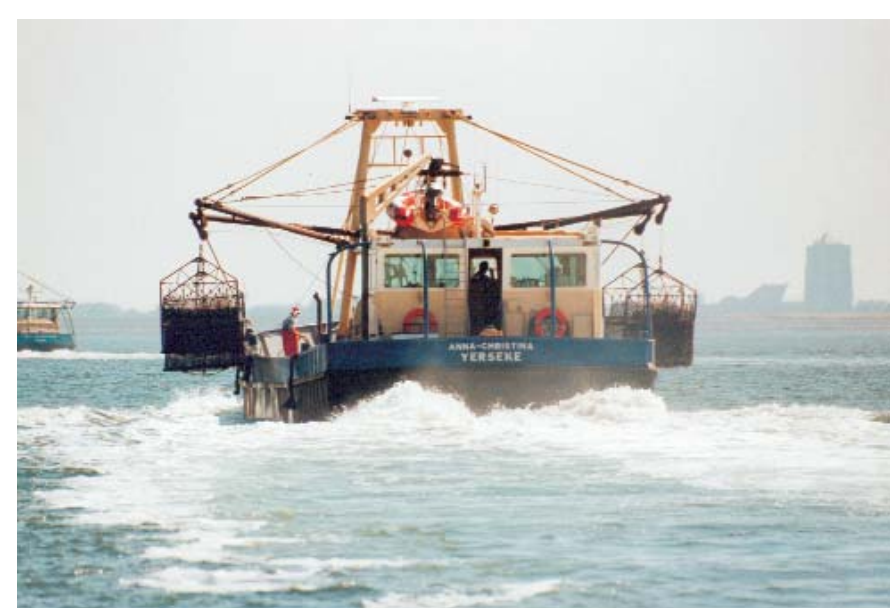

fig. 39 Fishing for mussels on the Eastern Scheld
The delta engineering works had a very negative mpact on the fishing and aquaculture activities. In the artificially created lakes most species disappeared (§3.2), but even in the partly open Eastern Scheldt the fish and crustacean harvests collapsed after construction.

To compound the difficulties faced by mussel and oyster companies following the works, a parasite has recently harassed the mussel fields causing the transfer of a large part of the industry to the Waddensea in the north of the country. Now, only 2000 ha in the Eastern Scheldt are cultivated for mussels; almost 2/3 of the total area (5600 ha) has moved to the Waddensea. Similarly, oyster culture has barely overcome the effect of the imported disease Bonamiasis. The industry now consists of only 16 companies all situated in the delta (Eastern Scheld and Lake Grevelingen); the harvest of 1400 tons of oysters are worth 5 million euro a year.

The fish population changed after the closure: the number of species declined and the composition altered. Commercial species such as cod and sole have disappeared while new, less popular species such as the Black Goby, have appeared ${ }^{14}$

4.1.2 The need for new land: agriculture Providing food for the growing population was the main driver for large-scale land reclamation and made the building of dykes necessary. Incoming sea water was a hazard; not only because of the risk of flooding itself, but also because of the damage that brackish water causes to traditional crops. Large-scale drainage of the land behind the dykes was carried out to increase agricultural yield. Surrounded by salt water, the ground water beneath the arable land was saline as well. Agriculture was practised in a shallow fresh-water layer drifting on top of the salt water. The limited availability of fresh water formed the main constraint on modern agriculture. Outside the dykes, natural sedimentation went on. Whenever th salt marshes rose high enough for use, new dykes
were built to incorporate them into the arable land 


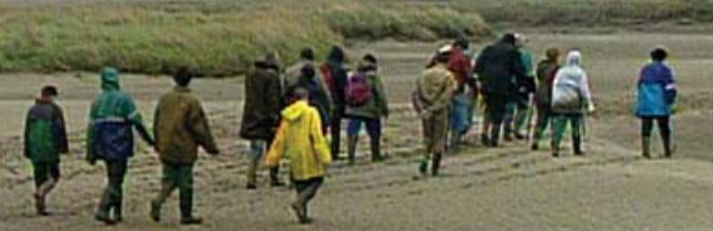

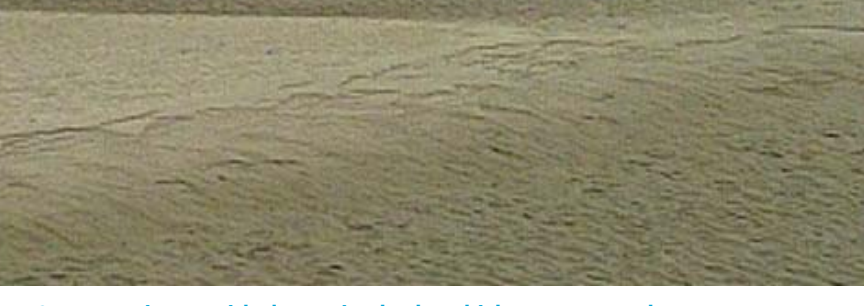

fig. 40 Ecotourism: guided tour in the brackish water marshes

of the growing islands. This process lasted until deep into the 20th century. Around $1900,46 \%$ of the working population were farmers. They produced mainly grains and these are still the most important crops. The economic importance of the agricultural industry has now declined: it employs $7 \%$ of the tota working population (8000 people) accounting for less than $3 \%$ of the income in the area. Modern developments in the world market and within the European Union, make the future of agriculture, in this area at least, uncertain.

The delta engineering works had a very positive influence on agriculture. Large volumes of salt water were turned into fresh water for irrigation, to maintain the freshwater bubble, and to flush brackish water out of the ditches and canals. As this delivered higher agricultural productivity, it proved to be an important argument for the engineering response after the 1953 disaster.

4.1.3 Trade, industry and shipping

Flanders was one of the earliest industrialised areas of the world; in the Middle Ages a prosperous clothing industry developed here. The products were exported and cities and harbours flourished. In relation to the rest of The Netherlands, Zeeland too was quite heavily industrialised in the second half of the 19th century. Around 1900, industry and services already accounted for $52 \%$ of the jobs; this figure is $92 \%$ now, bringing in 7 billion euro a year! Chemical, metal, electronic and shipbuilding industries are now the main economic drivers along with transport of the products.

28 Changing estuaries, changing views
Rotterdam harbour developed mainly as a result of its position at the mouth of the rivers Rhine and Meuse. since the St Elizabeth flood, which changed the flow and sedimentation patterns in 1421 , the harbour had to deal with increasingly shallow channels. Instead of changing the location to deeper waters, in 1871 the Nieuwe Waterweg canal was dug. Since that fateful decision, the Rotterdam Harbour authorities knew that they would have to dredge forever. At first there were attempts to keep the harbour open through this canal, but ships' draughts became deeper and finally. infrastructure investment moved towards the sea. (fig. 42)

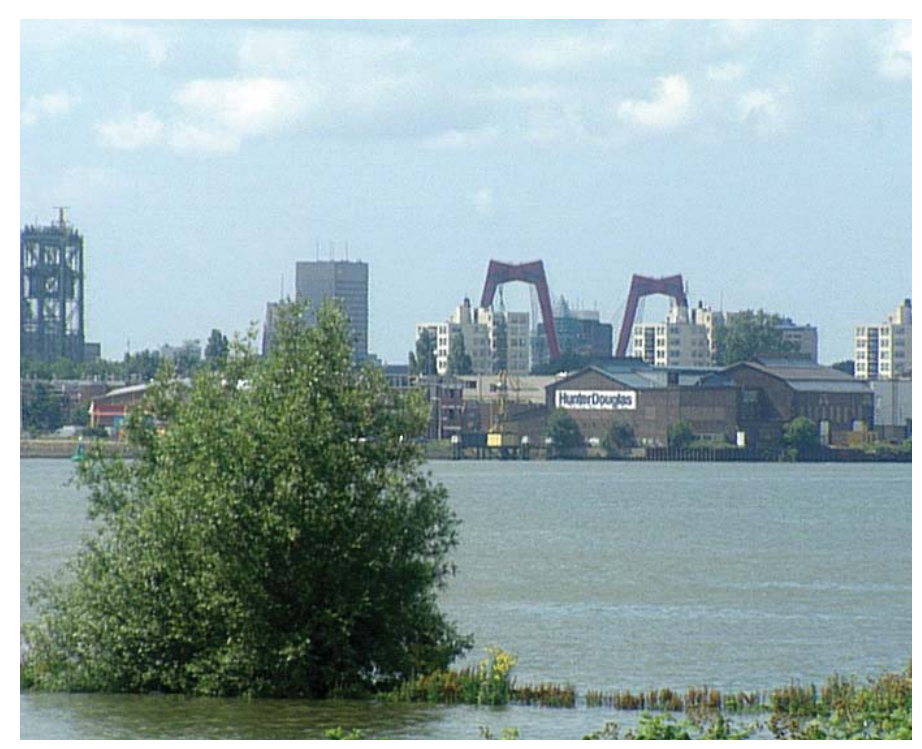

fig. 41 The Port of Rotterdam

The choice made by Rotterdam to invest in the Maasvlakte instead of the Haringvliet was a very good one. The decision avoided the penetration of salt water further inland, which would have occurred if the existing shipping routes were to have reached the required depth for large vessels. This would have caused problems for agriculture and the production of drinking water. A positive side effect was that, by keeping sea-going vessels in sea water, the sea arms would remain less affected. The need for large hydromorphological operations remained low. In contrast, Antwerp harbour remained located in its more inland area. This harbour can only develop and

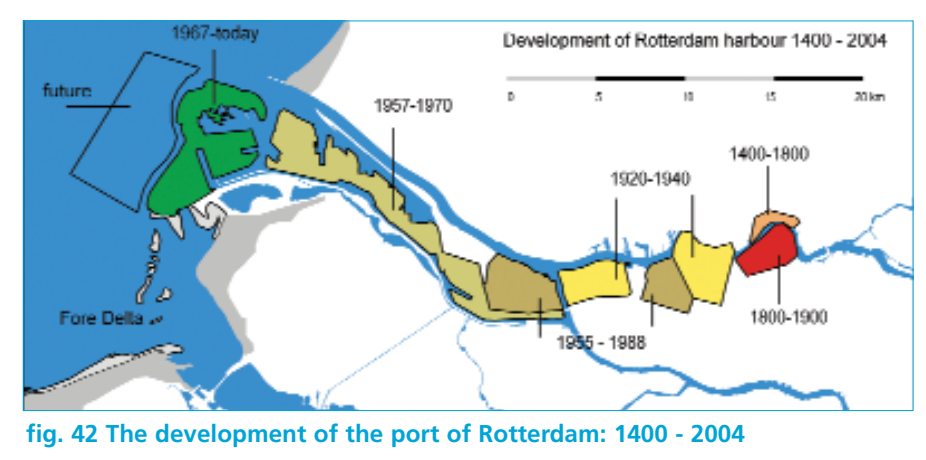

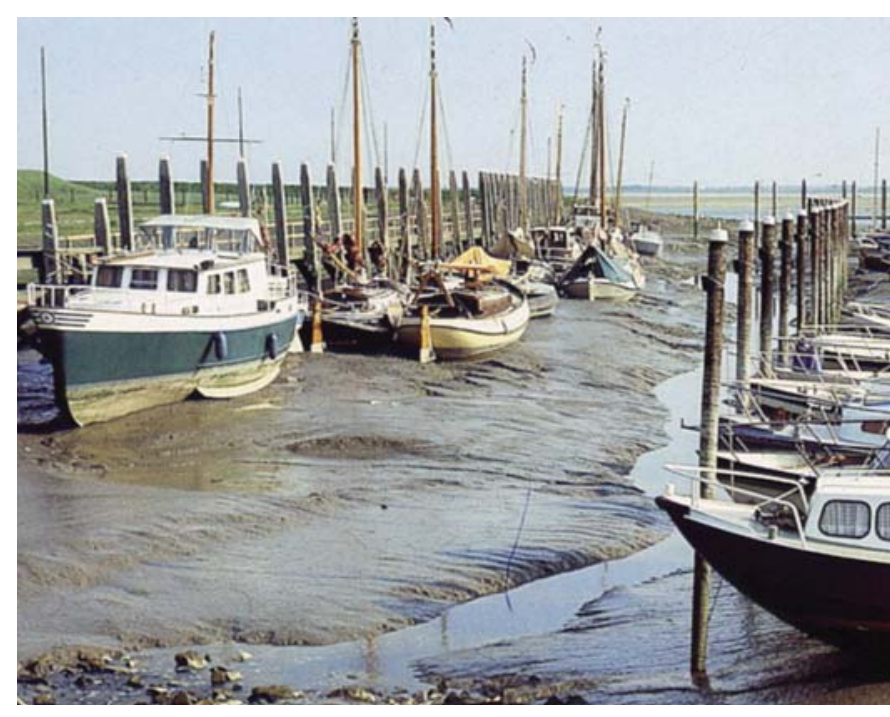

grow if huge alterations are made to the sea arms, causing extensive hydromorphological impacts.

The Delta Works were designed in such a way that trade, industries and shipping were not affected. The tide-free shipping lane between Rotterdam and Antwerp confirm the influence of these industries on the decision-making process $(\$ 5.1)$

4.1.4 A new industry arises: recreation

With the decreasing market for agricultural products, other economic activities have to be found for the

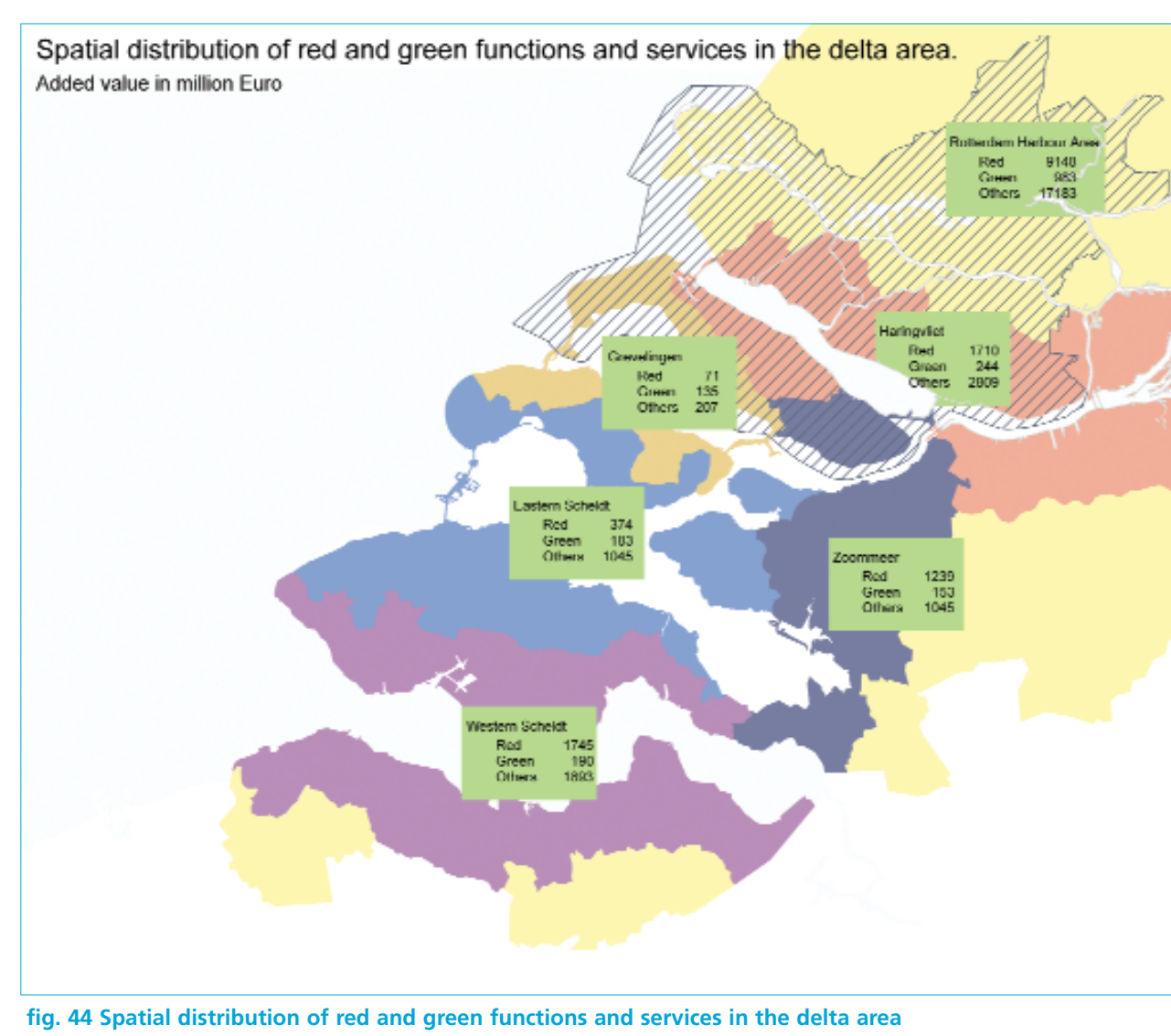

region. Besides trade, industry and shipping, . revenue for the south-western part of The Netherlands. The delta area is already a popular recreation destination. Angling, deep-water diving, swimming, sailing motor-boat cruising, relaxing on the beach, camping visiting the historical towns and eating mussels are popular pastimes. Since the 1960s, leisure time has expanded and recreation provisions have become an important component of the spatial planning process. Today, more than 3 million tourists come to the delta area each year, providing an annual income of more than 900 million euro.

The delta engineering works changed the systems, but recreation is still possible. Instead of going to the sea coast, people go to the shores of the lakes; leisure activities have not suffered. On the contrary, the thousands of people.

\subsection{Delta economics}

4.2.1. Non-delta economics in the delta

The delta region only contributes $5 \%$ to the Dutch economy: the area makes 30 billion euro of a total gross national product of more than 600 billion euro (1997). This is far less than the average production by area in The Netherlands. To compare: the size of the economy of Rotterdam harbour (80 billion euro) is 2-3 times larger than that of the entire delta region while the surface area is much smaller.

Little of the economy of the delta is related to its watery character and could have been developed anywhere in the country. Fewer than half of the economic activities use the water supplies (agriculture, industry), while the real water-bounded activities (fisheries, sand supply, maritime sector) represent only $5 \%$ of the loca economy. In this sense, the strength of the region is not exploited.

Although the area is a green (nature) and blue (water) oasis of outstanding landscape quality, the economy turns its back on these characteristics. The 
spatial planning map illustrates this situation very well. the delta area is green, but the land use infrastructure and industry (fig. 44).

4.2.2 Economic effects of the 1953 disaster and the building of the Delta Works

The catastrophe of 1953 was, apart from the human tragedy, an economic disaster: most of the

livelihoods. Some of them moved to other $p$
The Netherlands or migrated to Canada and Australia. The 1953 flood on top of the economic recession after the war, drove 230 families to move to other regions in The Netherlands or abroad.

The Delta Works have had a positive economic impact on the region and on The Netherlands as a whole.

Demonstration of the capability to translate the newest hydrological theory into technological applications, had a positive influence on exports of the technology and probably still has. From the beginning this expected spin-off was a major argument in the decision-making process that led to the construction of the Delta Works (\$5.2 and \$5.3).

\section{Rationale of decision-making in water management and spatial planning}

Directly after the 1953 disaster, a plan was launched to close off all Dutch south-western islands with one large dyke (in fact, this plan had been put forward before). Later that year in the Royal Speech, the Queen declared that everything would be done to guarantee safety in the affected areas. It is obvious that the decision to repair the dykes had already been taken implicitly. The long tradition of land reclamation made it culturally and emotionally impossible to consider any other option, and the technical means existed. Prior to the execution of any intervention or measure, three steps have to be taken: there must be a perception that intervention is inevitable (\$5.1), an appropriate measure must be identified (\$5.2) and the cost-benefit analysis must have an acceptable outcome (\$5.3).

\subsection{Context of decision making}

If authorities are convinced that business-as-usual may lead to disasters such as flooding, there is strong motivation to either change the land-use scenario or to intervene in the natural system. The latter is generally chosen. After all, if the natural system can be adapted, it will not be necessary to change landuse functions, no new skills will have to be learned and no new economic drivers identified. Only evidence of long-term undesirable side effects may convince administrators to make greater efforts to modify land-use functions so that they are in line with the natural environment.

In 1953, the cultural and political climate did not on the profound investigations which would have been required to produce such evidence. Already before the second world war (WWII), it had been concluded that the dykes in the south-western part of The Netherlands would not be able to resist a severe storm. In 1937 the Directorate for Public Works and Water Management developed a plan to improve the situation by raising the height of a number of dykes and by some other engineering works. Because of the low financial priority accorded to the plan during WWII, it was not executed. Moreover, maintenance of the existing dykes was not carried out properly, again because of the war. All this made the 1953 disaster possible. Although several people warned about the large-scale effect of drainage and land reclamation, their concerns did not reach the public or the administrators ${ }^{15}$. Because the administration had failed to protect the inhabitants of the south-western delta for such a long period, all financial means had to be used to make up for this negligence.

There are two main groups of decision-makers according to attitude to risk. Firstly, those who want to fully understand the effects of flood management because they follow a strong sustainability approach and observe the precautionary principle. Secondly, there are those who follow a less sustainable approach and are often only interested in those effects that have direct financial consequences (reflected in market prices). Apparently the latter group was in charge in 1953: the decision was made to use the technical ability to manipulate the natural system in such a way that safety for people and property was guaranteed forever. And the financial means to do so were granted. Only the voices of shipping and trade interests proved to be powerfu enough to keep two waterways open, to the harbours of Rotterdam and Antwerp.

\subsection{Identifying measure}

Once the decision is made to intervene, an appropriate measure has to be identified. The type of measure will depend on the available (technological) knowledge and means. In spite of the high political stakes, it is striking that the dykes were not immediately raised after the 1953 disaster. It took 25 years to build the engineering works; in the meantime safety was not improved at all in some places.

Shortly after the disaster, on 21st February 1953, the Minister of Transport and Water Management 
brought together a commission of 14 experts (12 civil engineers, an agricultural engineer and an

economist). Obviously, enveronmentalists were not represented in this group. This 'Delta Commission' had the task of designing a way of minimising the risk of a repetition of the events of February 1953. In May of the same year, three months after the

disaster, the first plan was presented. Two alternatives were offered: to raise all coastal dykes $(700-1000 \mathrm{~km}$ in extent) by 1 meter, or to shorten the coastline by large engineering works over tens of kilometres. The Commission recommended the second option. In 1955, it presented its definitive proposal which was translated into the Delta Law and approved by parliament in 1958 .

Safety was not the only argument behind the design of the Delta Plan. Besides the building of five primary dykes to strengthen protection from the sea, five secondary dykes were also envisaged in order to improve water balance and water quality, and to provide a non-tidal shipping lane between Antwerp and Rotterdam. Several compartments were thus created: water bodies not only cut off from the influence of the sea, but also from the rivers and from each other. The construction of the

compartments made it easier to control the water masses and their erosive forces. Further, agriculture would benefit.

In 1972, strong opposition from nature conservation groups and fishermen became part of the political discussion surrounding enclosure of the Eastern Scheldt. As a result of this determined public participation, a new investigation was started and in 1976, the decision was taken to ensure that the storm-surge barrien allowed a semi-open connection between the Eastern Scheldt and the sea.

The 1953 storm affected Belgium and England as well. In England there was extensive material damage and the loss of human life (fig. 21). There, the decision-making process developed along similar lines to that in The Netherlands. A dam was built to protect inland areas from further disasters. A governmental inquiry was organised which revealed the inadequacy of the coastal defences. In the following years, all defences were raised by up to 2 meters. The spectre of a major storm surge flood in London led to the constuction of the Thames Flood Barrier near Woolwich, which became operational in 1982. In Flanders, dykes were also improved but no barrier dam was constructed. Much later, in the 1990s, Belgian engineers developed quite a differen approach to the problem. Controlled Inundation Areas (see §6.3).

\subsection{Cost-benefit analysis}

investment is subjected to an assessment of costs compared to the expected benefits. In the case of large engineering works, the objective of a costenefit analysis (CBA) is to weigh the (economic) advantages and disadvantages of the selected measure(s). A negative balance gives an indication of the sacrifices that society has to make for those aspects which cannot be valued in money; this is called 'public pricing'. Because a CBA relies on a large set of assumptions, the outcome can never be entirely objective.

\subsubsection{The cost-benefit analysis of the} Delta Works

Tinbergen, the main economic analyst for the Delta Works, carried out a CBA of the Delta Plan in 1953. He split the costs and benefits into two categories: those related to the increase of safety (the construction and maintenance costs of dykes and dams and the benefit of increased protection of capital) and those related to the creation of economic benefits other than safety, mainly agriculture (increased productivity as a result of reduced drought and salinisation). Moreover, realisation of the Delta Plan was expected to stimulate development of the hydraulic sciences, technological innovation, to create opportunities to implement projects in foreign countries and to increase the prestige, goodwill and national pride of The Netherlands. The costs and benefits of land reclamation, improved infrastructure and recreation were also included in his CBA.

To balance the budget, Tinbergen used an extra post representing the price society would have to pay for the benefits that could not be monetarised, for instance increased safety. This "closing entry" was of the same order of magnitude as the material damages of the 1953 flood: according to Tinbergen close to 600 million euro. The Central Planning Bureau showed later that year that the total estimated damage was 500 million euro, almost 5\% of the national income of The Netherlands at the time. By way of comparison: the costs of the Delta Works that were originally estimated at 1.6 billion euro, turned out to be more than 5 billion euro. This is ten times greater than the economic benefit if calculated on the basis of the damage that would be prevented by a storm similar to that of 1953 . It should be noted that the construction of the storm surge barrier in the Eastern Scheldt is responsible for a large proportion of the costs (3.6 billion euro of the total 5.5 billion ouro) Not all (3.6 bilin have been foreseen by Tinbergen.
Other analysts also explored the benefits of the Delta Works. Van Dantzig aimed to derive the value attached to the protected area in order to justify the costs of the Delta Works. He tried to include the nonmaterial value of the impact of a disaster such as the fear people suffer for all their lives after a traumatic experience. Van Dantzig calculated that the adoption of the Delta Plan implied a value to be protected of at least 3 billion euro. The approaches by Tinbergen and Van Dantzig illustrate how assessment of the effects of large infrastructure projects may vary among analysts and consequently among decisionmakers. It also illustrates that the real costs are always higher than predicted.

According to Tinbergen and Van Dantzig, noneconomic effects should be taken into account as well. These cannot be fully quantified in a CBA, but decision-makers should be aware of them. These would include the loss of human life that may be prevented and ecological values that may be lost 


\section{Decision-making processes in a changing context}

Decisions are taken according to the socio-economic insights prevailing at the time. It is usually assumed that trends at the time the decision is made will continue to develop in the same direction. However, the context changes. For instance, economic developments may be different from the assumptions (agricultural development declined) and the

environmental circumstances may change (climate change, rising water levels). Moreover the perceptions of society concerning safety and environmental problems may also change drastically.

6.1 Declining safety

6.1.1 Improved safety leads to new investments: risks are growing

When dealing with a flood-prone area, the concept of risk is central (see §5.1). Risk is often defined as th by the consequences of that event:

Risk $=$ Probability $x$ Effect

When we try to make this risk calculation for the year 1953 , and fifty years later for 2003, we find that the probability of a disaster has declined, but the effect has increased dramatically: more people and infrastructure will be damaged by a flood such as that of 1953, if it occurred now. However, it has to be recognised, that the effect of a flood disaster nowadays might be less severe than in 1953 as a result of improved communication and evacuation plans. Nevertheless, the rise of the water level would occur much faster than it did 50 years ago: the land has sunk and the dykes have been raised so the polders would fill up more rapidly. While everybody feels safe in the shelter of the large constructions, it can be stated that the risk has actually increased, not decreased. From this point of view, the Delta Works are just one more step in a process which has lasted for 1000 years. The constant factor is that every measure to improve the safety of the area is followed by more investment and a higher population number: greater technical safety (lower probability of flooding) is always cancelled out by the risk of greater numbers of deaths and more costly damage.

6.1.2 Physical changes and rising sea level: risks are growing

The promised safety decreases every year for another reason. Before the 1953 disaster, the chances of a dyke breakthrough was $20 \%$ each century, so once every 500 years (severe) flooding would occur. The question was obviously not if it would happen, but only when it would happen.

After the disaster, and until now, the safety of the Dutch delta is computed at 1/4000: once in 4000 years a serious flood is expected to occur. For the more densely populated area of Rotterdam this probability is $1 / 10,000$. Although the exact probability is hard to measure, the defences are kept at this safety level: every five or ten years the dykes and engineering works are checked and improved (raised) if necessary.

Although attempts are made to maintain the agreed flood risk ratios, this strategy cannot be followed

forever. Because of the subsiding of the western part of The Netherlands, rising sea level and more extreme river water fluctuations due to climate change, we will end up living behind enormous dykes. Large pumps will have to be built to remove the seepage. The difference in height between sea level and the hinterland will further increase so the effect of a flood would be catastrophic. This situation can hardly be referred to as 'safe'.

It has to be concluded that, from the moment the first dyke was built by the monks, the endless spiral of "fighting the waters" was begun. This will usually occur in other comparable situations: the combination of altering the natural processes and increasing use of the 'safe' area will lead to the need for more severe measures. At some stage, the current approach of raising dykes and building dams will no longer be an option. Other solutions will have to be found to keep dry feet and to return to a more natural situation (see §6.3)

\subsubsection{Standards of safety}

In The Netherlands safety standards are set by the "Wet op de Waterkering"(Law of Defence against Flooding) of 1996. Under the law, for the estuarin area, the standards of 1953 are maintained.

The standard is 1:10,000 and 1:4000 years. Three groups of arguments influence the standard. Firstly, 
the water level. The expected maximal level of storms, sea-level rise, tide and wind and lowering of the land (due to shrinkage as well as sinking of part of the continental shelf) belong to this group. The quality of the dams, dykes and sluices forms a second dykes is the third. The expected loss of human life is also in the third category.

Although several of these factors can be calculated or standardised, others cannot. In the end the standards are a political choice.

The law says that every five years there must be an evaluation of the condition of dams, dykes and sluices. Whenever a shortcoming is found it has to $b$ repaired. Whenever calculations from the first category, e.g. rising sea level, makes it necessary, dykes and dams must be adapted. There is, however, no obligation to reconsider the standard of safety against the arguments of the third group, the value of goods and human life.

\subsection{Changing views}

6.2.1 Changing attitudes towards natural systems and technological approaches

Decisions about managing the Dutch delta were based on contemporary knowledge. This applies to the importance of the morphology and ecology of the system, but also to the technical solution chosen. The war against the violent forces of the sea had to be won with physical barriers. After 1953, raising the existing dykes was no longer a convincing solution although high, strong, properly maintained dykes might have avoided the disaster. A statement had to be made: the Delta Plan with its huge dams was designed with 'safety forever' in mind.

During lengthy projects such as the Delta Works, new ideas or concepts frequently displace those underlying the project design. During the construction of the Delta Works, protests were already being heard. As a result, the Eastern Scheld branch was kept partly open. Over the past ten years, questions have been raised about the desirability and usefulness of the rigid technological approach. Are more and higher dams really the best solution? Aren these measures neglecting the rising level of the seas? Is an approach that opposes the natural behaviour of an estuary the best idea, or is it possible to envisage solutions that work with the forces of the sea and the characteristics of the estuary, rather than against?
6.2.2 Changing developments in spatial planning

In 1953, most of the affected area was rural and agriculture was the dominant economic activity. The chosen solution was probably the best under the circumstances and within the cultural tradition. Agriculture, however, has since lost its pre-eminence in the now-urbanised Dutch society.

Agriculture itself has been industrialised. Intensive branches such as meat, vegetables and flower

production need more and more capital inputs, and less farmland. In The Netherlands, the future of those forms of agriculture which use large areas of land is very uncertain. Some predict almost no land use in that form, as the opening of the world market and the enlargement of the European Union to eastern European states makes it cheaper to produce elsewhere. Others predict development towards more extensive land use: that is, fewer but larger farms that use more land and less intensive techniques. These two developments could occur at the same time.

The outcome of a cost-benefit analysis depends to a considerable degree on such forecas space. Once the drive for more (agricultural) land disappears, a process opposite to that of the last 1000 years becomes possible: giving land back to the sea.

\subsubsection{Adaptation of the cost-benefit analyses}

The maintenance costs of the Delta Works are very high, higher than Tinbergen had estimated in his CBA. Tens of millions are spent each year to keep them in good condition. The maintenance of the storm-surge barrier, for instance, costs 15 million euro annually. Other costs were not foreseen at all, for example the projects to locally restore disturbed nature, and control of the water quality problems. To avoid large-scale erosion of the banks, bank protection has had to be put into place at a cost of million euro per kilometre over several hundred kilometres.

Moreover, with the worldwide degradation of ecological quality, the economic value of ecosystems is being more widely recognised. This value was neglected in the past including in the CBA framework used by Tinbergen and Van Dantzig. Attempts are now being made to include the economic value of (aquatic) ecosystems in the decision-making process when interventions are planned. Applying the economic values attached to an estuary, for instance fisheries, it can often be shown that human intervention results in huge economic losses.
Calculated in this way, the economic value of the

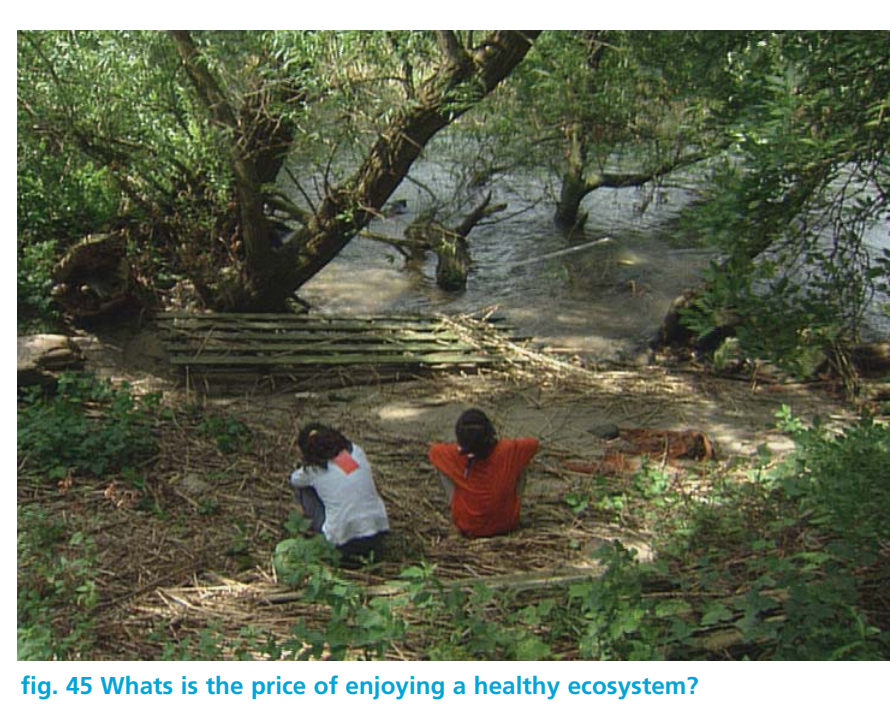

Dutch south-western estuary will have declined by $40 \%$ between 1900 and 2000 .

But in the end it is impossible to attach monetary values to all that nature offers. The ethical discussion should be added because intrinsic values are not monetary values. What is it worth to be able to walk along a pristine beach and leave problems and stres behind you? How much do you want to pay to let your children swim in the sea without worrying about the pollution? Whats is the price of enjoying a healthy ecosystem?

6.2.4 Changes in decision-making processes: international water management

Managing a delta seems, a priori, to be the responsibility of the people who live in it. However, trends in global water management are towards institutional arrangements in the wider perspective of a riv basin. The European Wate Framework Directive formulate this as follows: Art. 3 subsection 3 states: "Member States shall ensure that a river basin covering the territory of more than one Member State is assigned to an international river basin district. (......) Each Member State shall ensure the appropriate administrative arrangements (......) for the application of the rules of this Directive within the portion of any international river basi district lying within its territory". The tidal area upstream of the Scheldt up to
Ghent in Belgium belongs, from a water system point of view, without any doubt, to the delta: the system is thus transboundary.

On the level of the entire river system, the countries in the Scheldt Basin are aiming at comprehensive water management that integrates policy in all of its basin countries (ICBS, 2000). The first step in international co-ordination of river management has been taken. Although a supra-national water management commission might only be realised in the far future, co-operation on the water system level, centralised in one international commission, could certainly be achieved in the coming years. This means that French, Walloon, Flemish and Dutch stakeholders in the basin will all play a role in decisions about the delta, as far as they have an
impact at the scale of the whole basin. Regional issues still remain under the responsibility of regiona institutions, as is prescribed by the EU subsidiarity principle. (Van Ast, 2000)

\subsection{A different approach:}

the Flemish view

The southernmost branch of the delta, the Western Scheldt, has remained open to allow shipping to reach Antwerp harbour. Artificial deepening of the navigation channel for ever bigger ships reinforce the natural tendency of the Western Scheldt to enlarge the tidal volume. The danger was felt especially in the upper part of the system. It was calculated that the city of Antwerp itself was at ever greater risk of inundation. As a barrier dam was financially and politically out of the question and thinking about natural systems was changing, Flemish engineers, morphologists and ecologists, after studying and better understanding the system, came up with a

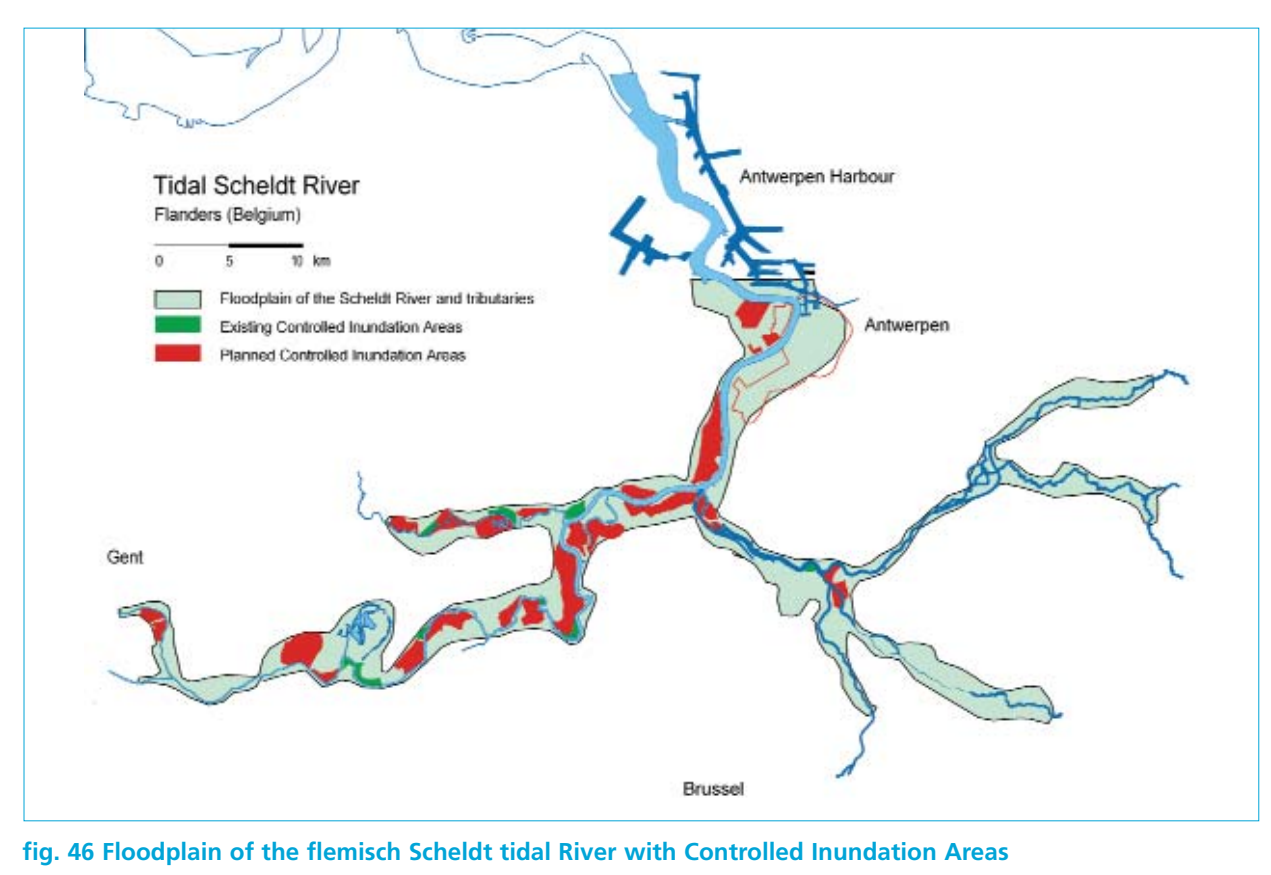

cheng 


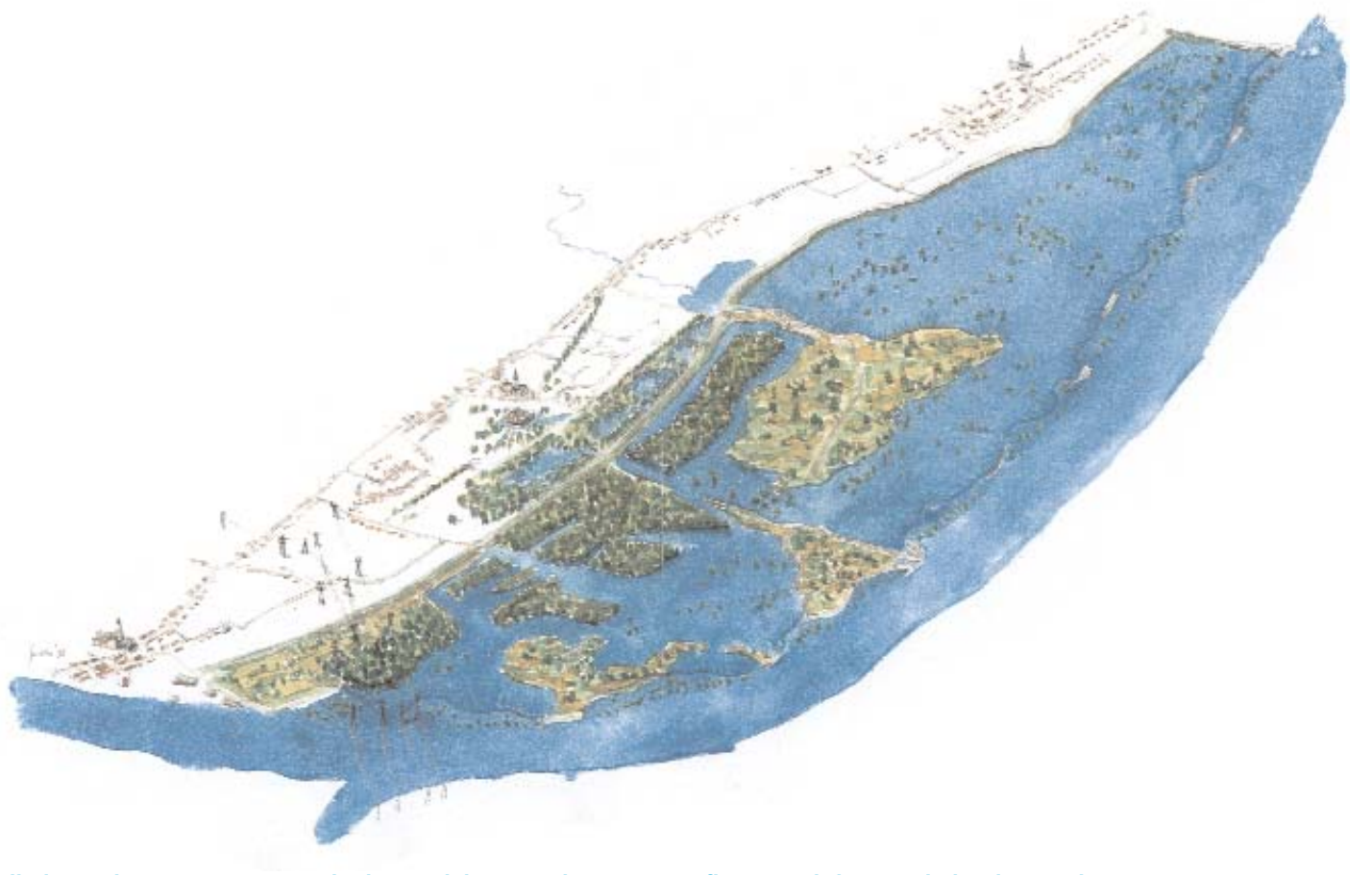

completely new approach. (Heniisen en Meire, 1988 Meyvis 2003., Van den bergh et al 1999, 2003)

The new approach against the dangers of flooding was found within the natural characteristics of the estuary. During a centuries-long history, the medieva river upstream of Antwerp was gradually changed into a tidal river. To prevent flooding, the Flemish invented a system of Controlled Inundation Areas (CIA) along this estuarine river: giving back the floodplain to the tidal system in a controlled way (fig. 49). Simply removing dykes in places where
(uninhabited) floodplain were still intact would not have been effective. This would have caused the tide to come in twice a day, changing the river forelands to freshwater tidal marshlands, and increasing the tidal volume once again. Instead, the dykes have been lowered in such a way that, during severe storms when Antwerp is in danger, the dykes start to overflow into selected polders. New, higher dykes in the hinterland protect the neighbouring villages an cities. The top of the flood is thus removed in an elastic" way, playing with the natural forces instead of opposing them, within the limits of the natural system.

This system has some more advantages. Firstly, the process of silt sedimentation is allowed some life again. In order to be effective in times of extreme floods, the dykes of the controlled overflow polders are low enough to allow 'normal' high water to fill the polders, up to eight times a year including lesse floods. In this way the area will slowly grow
following the rise of the sea level. were presented as well. more crucial, the existence of three nuclear plants

A second advantage is that by using the in- and outlet devices of the polders, the freshwater tide opportunity to restore on a large scale the natura conditions of a freshwater tidal system. At the moment, several areas covering a total of about 2000 ha are under construction (fig. 46). There are plans to enlarge the area to up to 4,500 ha. Apart from improved safety and the possibility to grow with the sea, a natural tidal freshwater river will reclaim its tidal plains. In the very densely urbanised area of Flanders, including Antwerp, Ghent and Brussels, a beautiful natural park will be created with

unprecedented ecological and recreational benefits.

In 2003, through an international body (ProSes), the semings and Dutch formulated outlines of a common sketch for sustainable development for the Scheldt estuary over its full length of about $160 \mathrm{~km}$, based on an earlier accepted long term vision for for the scheldt-estuary. The Flemish Controlled Inundationa Area solution was presented and, for the first time, similar solutions for the Dutch part of the estuary

Another new idea was formulated by the ProSes study: (Van den Bergh et al 2003) energy dissipation. According to this idea the energy of the waters is absorbed by its contact with the soil of the water bodies and (periodically) inundated areas. This draws on the fact that for waters with limited contact with the bed and sides of the channel, energy dissipation is low. In wide and shallow systems, however, the energy of the currents is absorbed to a much higher degree. ages. The highest parts of the tidal marshes, only
In terms of energy dissipation, the 1000-year development trend was towards cutting off the shallow waters from the sea thus diminishing energy absorption, allowing the floods to develop more force and cause more danger and damage.

Of importance to the Dutch estuary is a suggestion to open the connection between the Western and

Eastern Scheldt (Overschelde) to allow water to flow to the north again under storm conditions. This ide breaks the century-long tradition of orienting the islands and the flow of the sea channels in an eastwest direction: the north-south connection between both systems would now be (partly) restored.

\subsection{Artificial mounds}

Dykes are not entirely safe, and decision makers in the harbours and industries of the area did not want to rely on the 1:10,000 or 1:4000 safety standards. The huge investment in heavy industry and, even (two in Flanders and one in The Netherlands) put the value of potential damage very high indeed and called for another solution.

a flood exceeding the 1:10,000 level, the mounds will remain dry or only suffer shallow flooding during a short period.

Curiously, urban planning did not follow this strategy.

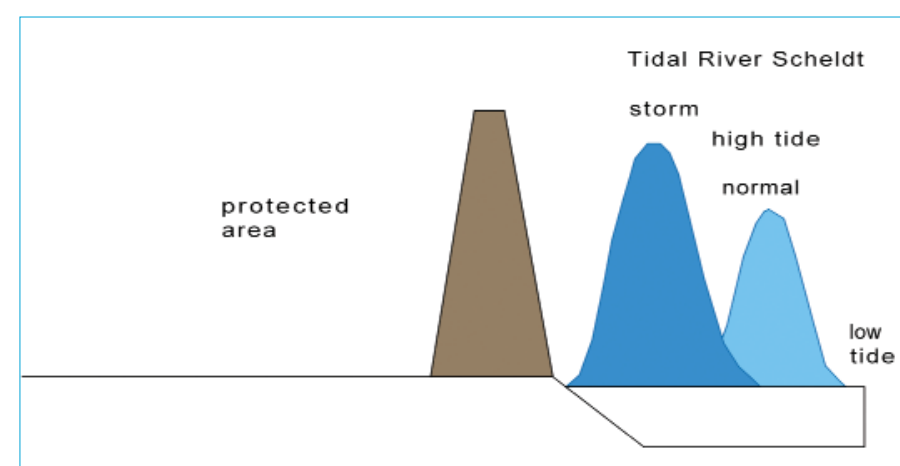

fig. 48 Scheme of the tidal Scheldt River: existing situation:
danger of uncontrolled flooding.

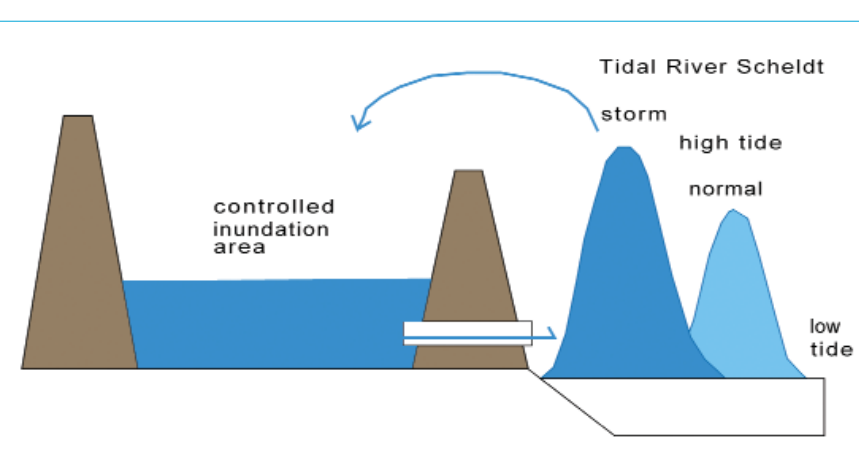
cattle. The revere storms, were used for grazing survive extremely high tides. Even the highest floods obey the rhythm of the tide so that on an artificial mound, or "terp", the worst that could happen was shallow covering of water for a few hours. In contrast, if dykes break, the land they enclose is flooded to a much higher level and the water stays longer. The lower the land the longer the water stays and the more dangerous the situation is. In the estuary, many places are at, or even some meters below, Main Sea Level.

Industry made a partial return to the safest possible strategy for flood prevention: large-scale artificial mounds. The large harbours and industrial estates are all built on mounds. Even in the worst case,

\section{fig. 49. Controlled Inundation Area along the Scheldt River: protection
against flooding.}

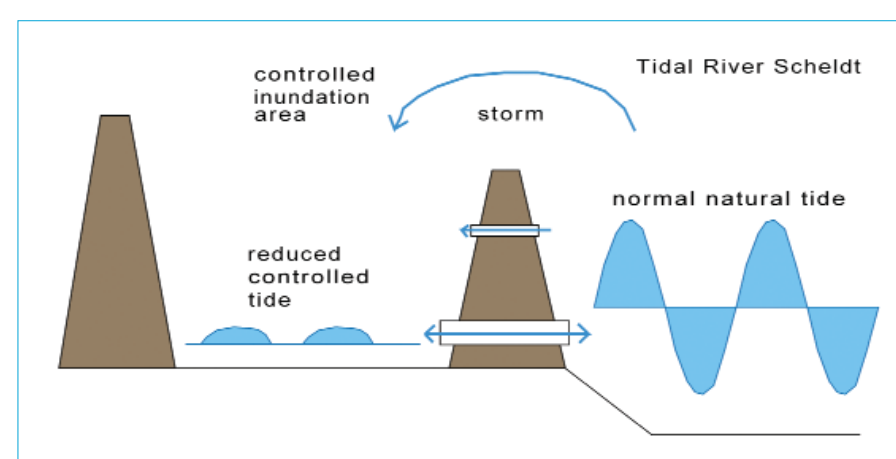

fig. 50 Reduced Controlled Tide: freshwater tidal areas along
the scheldt River. 


\section{Lessons learned and solutions proposed}

This report shows that much effort has been put into reclaiming and maintaining land in the south-western estuary. Decisions are made, great works are executed but, ironically, the risks at present are greater than they were in 1953 because of major investments behind the dykes.

Society and opinions are changing. It can now be said, without fear of ridicule and in light of the findings of this study: prevent far-reaching interventions in pristine estuaries! But, if deltas have been changed, the consequences can be minimised for humans and for nature by making adaptations to the strategy.

7.1 Better safe than sorry: do not

interfere in an intact estuary

7.1.1 The values of a natural delta

A host of new problems were caused by the most recent large and prestigious engineering work in the Dutch estuary (\$3.2) which followed centuries of
smaller interventions. It has to be concluded that changing an estuary without thoroughly understanding the system can lead to unexpected and very high costs.

Creating compartments in the estuary has led to lessons being learned about polluted sludge accumulation (\$3.2). It can be expected that if rivers upstream of a dam are severely polluted, then accumulation phenomena are likely to occur as they did in The Netherlands. Accumulation may proceed more rapidly in one compartment followed later by another, but the final result will be the same; lakeand riverbeds will become practically lifeless and unable to carry out their essential functions in water systems. Moreover, polluted riverbeds also act as storage areas. It is likely that, even if the origin sources of pollution are removed, contaminated sediments will continue to deliver emissions over the coming decades.

We have shown that an intact fully functioning ecosystem provides less costly and higher levels of safety than an artificial system (\$7.2.1).

When the decision was made to accept the Delt Plan, the authorities did not take into account the ecological consequences: the cost-benefit analyses did not include the value of the natural ecosystems. It is very hard to monetarise the economic value of nature and its processes (the same problem applies to the risk to human life and to historical buildings). Ecology should be included in the cost-benefit analysis and the decision-making process, both through economic analyses (albeit imperfectly) and through assessing intrinsic values.

\subsubsection{Changes in knowledge and} attitudes

A striking observation is that as soon as a dyke or dam is constructed, the inhabitants' relation with the natural dynamics of the system disappears. Shortly after construction, an embanked area will be used more intensively for living and working, usually to a degree which is out of proportion to whatever natural dynamics still occur in the area. Every improvement in 'safety' against the dangers of the natural environment is followed by new investments, and thus the risk is enlarged to, or beyond, the former level.

The long history of transformation of the Dutch delta shows that spatial changes are very often a series of small apparently unimportant adaptations, such as the draining of polders and the expansion of a city near the river mouth. These processes take place gradually, being all the more dangerous because they are not noticed. At a certain moment, the development can no longer be stopped. At that moment, economic growth can only be realised by more extensive and more radical alterations to the natural system. Attentiveness to the slow accretions of development may possibly avoid the

implementation of irreversible measures and allow the economy to grow in harmony with the landscape.

Apparently, it is extremely difficult to change strategies once spatial plans are in place, especially when it involves large engineering constructions such as the Delta Works. The large-scale drainage of embanked areas, the complete closure of three estuarine inlets (Grevelingen, Haringvliet, Veerse Meer) and the building of the storm-surge barrier in the Eastern Scheldt, are examples of interventions which are, to all intents and purposes, irreversible. But the values we attach to culture, nature and landscape change. Therefore it would be better to take reversible measures and avoid those that intrude too deeply in the landscape. A wide range of technical approaches are now available; it is possible to live in a water-rich landscape without destroying
the environment. 
Dutch engineering institutions learned a lot from the Delta Works and their skills were exported al over the world. The decision to build the dams in The Netherlands was probably inevitable given the water and land management traditions of the region and the socio-cultural perspective of 1953. However, the Dutch dams are not necessarily the best solution in other parts of the world. In places where there technological and socio-economic development technological and socio-economic development, engineering options for providing safety or enabling numerous.

In recent decades, better understanding of natural systems and functions has grown alongside a new less combative attitude towards estuarine processes. In applying these new insights, the same engineering skills are needed

The main lesson for other estuaries in the world is: first study the area as a system. Start a dialogue with the natural system and try to find ways of influencing it in an incremental manner. If this is impossible, try to find solutions within the natural processes

themselves, leaving as much as possible intact. Take into account long-term processes as a rising sealevel, or the sedimentation in the estuary.

\subsubsection{Alternative approaches: a society} in balance with nature

7.1.3.1 No dykes, no disasters: natural development as an alternative

Recently, a computer model has become available which simulates varying conditions related to land and water management and climate change (SIMdelta; De Vries/RIKZ, 2003). Application of the mode allows an exploration of possible morphological changes in the south-western delta area under specified conditions. Within the context of this report, two scenarios are intriguing

\section{1) No dykes, open estuary, no drainage}

If the inhabitants of the Dutch delta had not been focused on land reclamation but on aquaculture and fishery, the south-western estuary would be much larger than it is today. In this scenario only the villages and cities would be embanked or otherwise protected from, or accommodated to, high water levels. The importance of the wetlands and an open
estuary as a nursery for fish, waterfowl and molluscs estuary as a nursery for fish, waterfowl and mollus would have been recognised and preserved. The number of flood events would have been higher, but the impact (both socially and economically) lower. A disaster on the scale of the ' 53 flood would probably and the growth of peat would have matched the rising sea level caused by geophysical and climate changes. The model suggests that the population density would have been approximately what it is now. All the costs linked to dyke construction it is of the estuaries, water pollution and nature restoration would have been saved.

\section{2) Embanked islands, open estuary, no drainage}

If the inhabitants had decided to embank the islands without applying intensive drainage programmes, the total area of land above mean sea level would have been larger than now, but smaller than in scenario 1 In this scenario, the inhabitants would have been focused on trading, tourism and, to a small extent islands would have catered for the storage, handling and transport of goods. After embankment, sedimentation processes would have ceased but peat growth would have prevented subsidence of the soil. The weakness of the soil structure would, however, have required specifically adapted construction methods for housing, buildings and infrastructure. Flooding frequency would have been higher than in scenario 1 because the embankments would have raised the water levels in the river branches. However, the impact of incidental flooding would have been relatively low in the absence of soil subsidence. It is very unlikely that a flood of the dimensions seen in 1953 would have happened. All the costs linked to closing the estuary, water pollution and nature restoration would have been saved.

From the above, it can be concluded that a delta without dykes is safer than a delta with dykes; natural processes will prevent disasters. A dynamic delta is more durable and robust, while it is flexible enough to adapt to changing situations. A static delta, on the contrary, is not safe and increasingly vulnerable to severe flooding.

Projected into the future, this insight means that, in the Dutch case, if the importance of agriculture diminishes as expected, a new choice opens. A modern, sea-oriented society could be developed, with (large) harbours, industry, shipping and fishing, Housing on islands would be safe against flooding and surrounded by a shallow sea (\$7.1.3.2). We have every opportunity to do this moderately and wisely by keeping the land we need and giving back to the sea what is necessary to make it a more safe natural system. By doing this, large parts of the returned are will start growing with the sea, following the long-
term developments in the estuary (\$7.1.3.3).
7.1.3.2 Changes in land use: floating cities and living on hills

In many countries people live on the water instead of on the shores beside it. For instance, in south-west Asia, living in houseboats is common. This opens a perspective for different approaches to spatial planning in areas that are at risk of flooding.

The delta of the rivers Rhine, Meuse and Scheldt is an example of an area where people could live and work in places that are sometimes inundated. Dykes could be displaced, enabling (temporary) inundation and sedimentation processes to take place again. The land will raise itself, providing a durable alternative for the unreliable dykes. Houses could be built in the floodplain, constructed in such a way that the water cannot affect them, for example floating during floods or built on small artificial mounds as in pas centuries (\$6.4). While the 'mound-strategy' is already used in the Dutch delta for large investments, the inhabitants should be offered the same advantage. Risks to life would be reduced compared to the situation in which an unexpected breach of a dyke takes place.

Implementing the measures described above would introduce a sustainable way of rehabilitating nature and developing the specific characteristics of the estuary so that ecological productivity and the diversity of species are optimised. Economically, this type of development needs less maintenance, leads to lower costs for flood defence, fulfils the precautionary principle and decreases flood risks. The environment would be very attractive for older, highly educated and rich people: Zeeland could become the Florida of The Netherlands, providing unique living conditions in sympathy with the natural water environment. This would be spatial planning in accordance with the natural system instead of against the system.

7.1.3.3 Using the natural processes optimally: exchanging polders

When the natural dynamics are used in an optimal way, sea level rise, climate change and land subsidence can be easily addressed. Natura sedimentation processes normally keep up with these kinds of changes: when the sea floods an area more often because the water level has risen, suspended sediment is brought more frequently and height is gained more rapidly. This natural process can be use to maintain polders. When a low(ered) polder is abandoned and given back to the sea, the height of the polder will naturally rise. When the height of the land equals the water level again, the polder is safe and can be re-used. By using several polders in rotation, the level of the land can keep up with the sea level. Both agriculture and housing should have an adaptive character (i.e floating houses and salt tolerant crops). Less land can be used at a time because part of the area will lie fallow, but its use will be absolutely safe.

7.2 When changes have been made: making the best of an artificial situation

It is possible that current thinking would have led to another choice in the delta: the major works might not have been executed if all the impacts had been known beforehand. This knowledge was not however, available. Now that we have the unfortictions, we can make the best of an How should we proceed in The Netherlands, taking into account the present situation and expected future developments? The approaches offered below to minimise the negative consequences of our action in the past, could be used as a model for other countries which are facing a similar situation.

7.2.1 Find a sustainable way to improve safety

It is expected that climate change will increase the risk of inundation by the waters of the rivers Rhine and Meuse. As it is now accepted that dykes cannot be heightened endlessly, a new scheme for flood prevention is being developed along these rivers. High ground in the floodplain will be removed, side channels will be dug, and some embanked areas will be given back to the rivers. In the transition zone between the rivers and the estuary, some polders have already been restored to the waters. Another possible measure, which will probably be necessary, is the use of the delta to store high river water flows when they occur at the same time as a storm at sea which requires the storm-surge barriers to be closed.

The tidal flats could be restored by bringing dynamic back into the system (\$7.2.2). The value of the salt marshes as a natural flood defence is obvious, extensive salt marshes break the force of wind and waves and also function as a natural sewage purification installation. Furthermore, these habitats form an important maternity unit for fish and invertebrates.

Along the Western Scheldt, in the 'Ontwikkelingsschets 2010 Schelde-estuarium' the first proposals have been launched to give land back to the sea in order to dissipate tidal energy, to store water during floods, to restore estuarin 


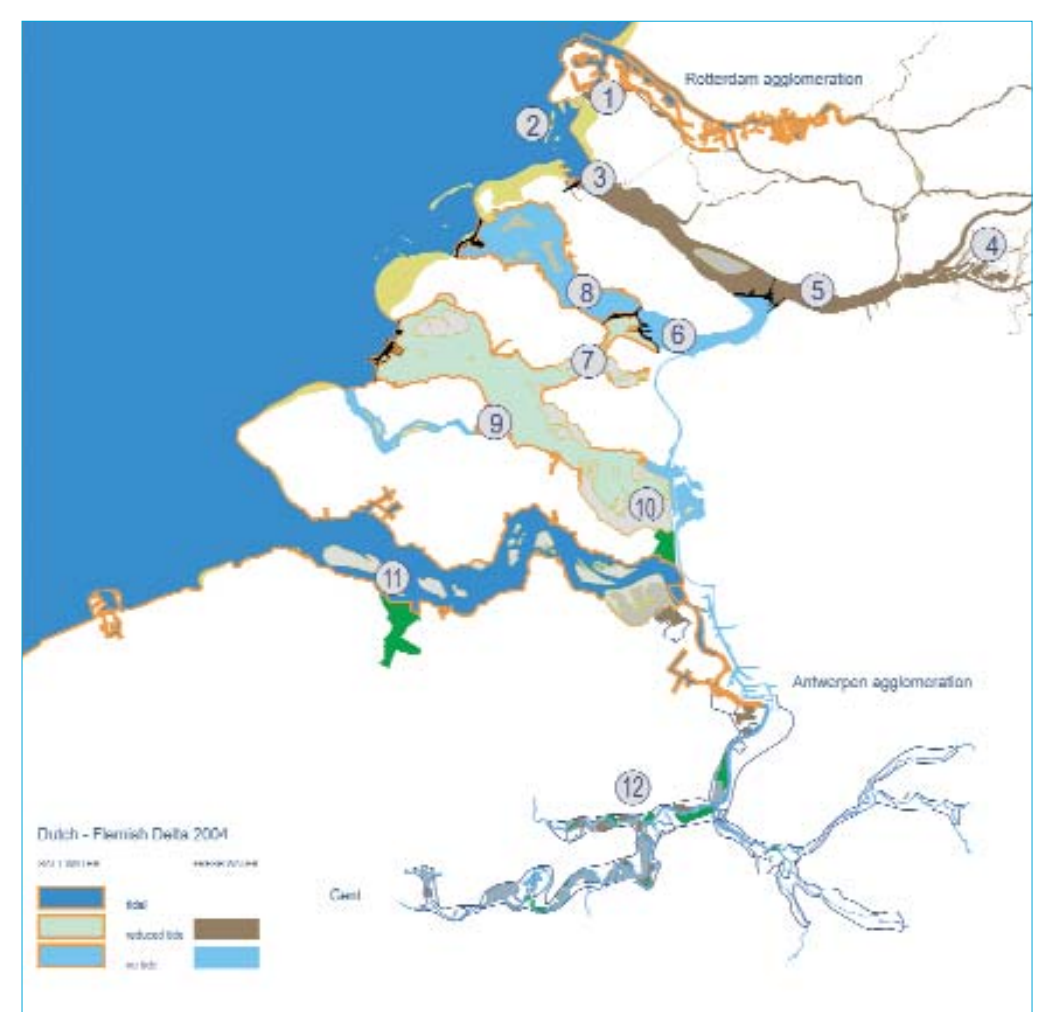

the seating lake Oostvoorne and lake Brielle to the sed

2 Fore-delta: undisturbed development of sandbanks alongside the coast, a new mouth in formation for the rivers khine

Opening the Haringvliet Sluices to restore the tides and the
brackish gradient from fresh to salt water

Removing dykes and restoring the freshwater tidal area in the

5 Sedimentation zone in the Hollands Diep branch for clean y sediments from the river Rhine

Flushing the eutrophic Krammer Volkerak with clean water

Connecting the Grevelingen both to the sea and the river

Connecting the Eastern Scheldt to the rivers Rhine and Meuse

Connecting the Eastern Scheldt to the river Scheld

1 Returning the reclaimed Braakman area to

the sea, for energy dissipation

(a) Controlled Reduced Tide along

the tidal river Scheldt could pass through the brackish water zone without too great a delay thus avoiding the problems a delay causes.

morphological and natural processes, and to the quality of the natural environment (\$6.3). In the southern part of the Eastern Scheldt (Overschelde), new north-south connection between the Western and the Eastern Scheldt is proposed. This would Western Scheldt to enter into the Eastern Scheldt and dissipate tidal energy.

\subsubsection{Bring back dynamics}

The lack of tides and current in the compartments is the cause of many of the problems. However, it is

quite possible to bring movement back into the area. If we change the Haringvliet sluice into a storm-surge barrier and/or open both Lake Oostvoorne Brielle in a controlled, reduced way, (fig. 51-1), it would be possible to restore the natural dynamics of tide, salt gradient and sedimentation. The opening of the two lakes would nevertheless be difficult because of the intensive urbanisation in the area.

A connection with the new sandy islands (Fore-Delta) alongside the coastline could upscale the natural value by a substantial amount (fig. 51-2). If combine with the development of large natural tidal zones along the borders of the lakes, it would result in an extremely scarce and highly valued ecosystem in the neighbourhood of one of the largest industria concentrations of Western Europe. Salinity gradients could be restored so that migrating aquatic animals

44 Changing estuaries, changing views incoming nutrients, and the transition zone between the natural system (for ecology as well as for fishery) could be arrested by letting in some water from the Rhine River via the Krammer-Volkerak (fig. 51-6).

The connection between the stagnant non-tidal saltwater lake of Grevelingen and the sea has already been restored in a small and experimental way. Here, more water and some tidal influence could be

restored by using the already existing siphon towards the Eastern Scheldt.

7.2.3 Allow the natural processes still present to develop

The Biesbosch (fig. 51-4) was created in the giant flood of 1421 . The former polder turned into a centuries to fill up most of it. During this period, the area was an ecological paradise where sturgeon grew, salmon passed on migration, and waterfowl was abundant. At the moment, the estuarine branch of the Hollands Diep - Haringvliet has no tidal activity (fig. 51-5). This means that yet another large and deep water body lacks the organising forces of tida energy. Here again, a centuries long process of gradual filling with fluvial sediments will take place and provide new riches for a mutilated system. In the sixties, Rotterdam constructed a completely
new harbour on a peninsula off the coast. Over the next 15 years this peninsula will be considerably enlarged. Together with re-arrangement of the sandbanks in front of the closed estuary, a new shallow sea is developing. As the river Rhine still brings silt to the sea, sand and silt deposits are present: a new and natural mouth of the rivers Rhine and Meuse is developing spontaneously (fig. 51-2). The only thing we have to do to support this process is: nothing! The opening of the Haringvliet dam will improve the situation.

7.2.4 Reduce eutrophication in the compartments

During the darkest period of pollution from the Rhine and Meuse, the Krammer-Volkerak (fig. 51-6) was closed from the Haringvliet to prevent the contaminated water entering the adjacent estuarine branch. The closed section was conceived as a freshwater system almost exclusively fed by rainwater from smaller rivers, although some input of Rhin and Meuse water had to be accepted. In time, however, it became clear that nutrient accumulation nevertheless occurred (mainly brought by the smaller rivers), causing mass blooming of algae.

Implementation of the EU Water Framework Directive (see §6.2.4) should help to reduce diffuse sources of nitrogen and therefore eutrophication.

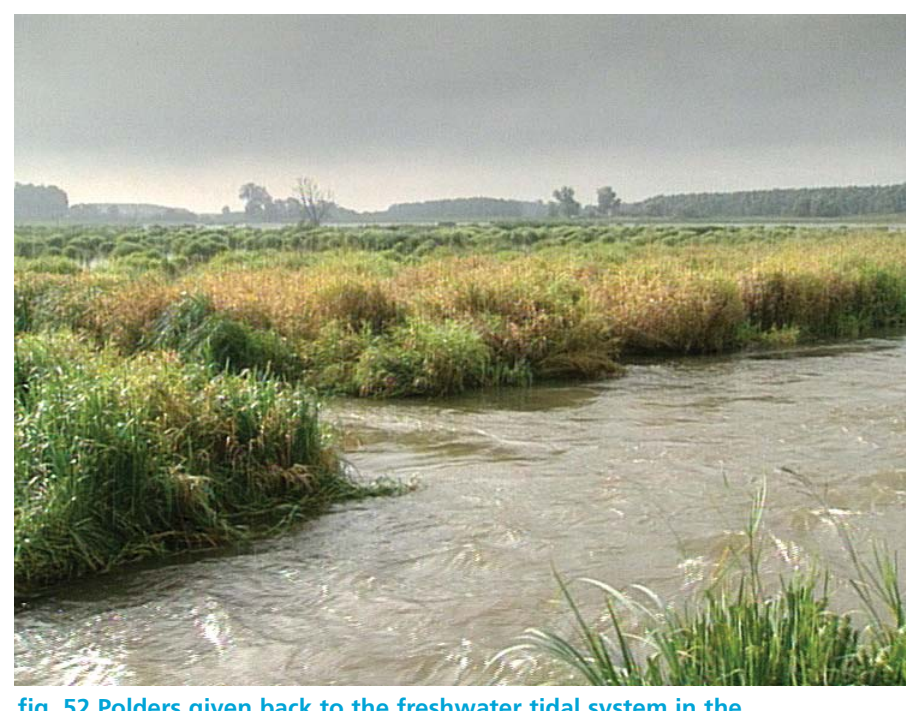

fig. 52 Polders given back
Biesbosch area (fig. 51-4)

Dredging and spoil-dumping change turbidity and thus primary production. This leads to an alteration in species composition because light is a key resource (see §3.1). It has been established that, in the $\mathrm{Ems}$ estuary, the modification of which has been less complex than that of the Scheldt estuary, concentrations of suspended matter vary more than two-fold due to dredging activities. In the estuary in the southwest of The Netherlands, a simila correlation between dredging and the volume of suspended matter has been observed. In this case the maximum increase is over three- or four-fold. These effects are probably not only due to human activities but partly also due to the loss of suitable sedimentation areas for fine suspended matter.

In 2003 a survey of possible solutions to the eutrophication problem was carried out. One suggestion for minimising it is to flush the artificial lakes with enough fresh water to decrease the residence time of the eutrophicated water and prevent the development of algal blooms. The problem is that this measure cannot been used in dry summer periods when little water is available but algal blooms are at their peak. Creating a saltwater lake or a more or les tidal estuarine area are the suggested directions for a sustainable solution. The problem here is that agriculture needs the fresh-water supply.

7.2.5 Find suitable land-use scenarios

The primary economic driver in the Dutch delta was agriculture. Since globalisation has enlarged markets, the rationale behind the fight against the sea to maintain reclaimed land for regional food supply has lost much of its value. Keeping in mind agricultural over-production in Europe, it is easy to conclude that there is even too much land. The case for agriculture 


\section{Recommendations}

in the delta is further undermined given that it has not been very successful.

Resource-use strategies should be sought which are compatible with the characteristics of the area. An economy based on fisheries and aquaculture (the exploitation of mussels and oysters) would have avoided declaring war on the natural system. The costs of maintaining an economic sector that does not fit into the natural system are always high. Costs are driven even higher when market conditions change and the large investments and modifications become disproportionate to the gains.

The delta area could become even more importan for recreation than it is already. Leisure time and spending have grown in the last few decades and the millions of people living in the densely populated western part of The Netherlands provide a ready market. The recreation industry could be expanded by changing land use; for instance by returning the ancient agricultural lands to nature. These lands have settled over hundreds of years of use, lowering and compacting the ground. Here, fresh water could stagnate, leading to interesting freshwater nature reserves. As these lands are situated near picturesque old towns, a perfect combination of culture and nature could be created. The ideas put forward in $\S 7.1 .3$ give some practical leads for such a strategy.

The same approach could apply to harbours and ports. Even though keeping the shipping routes in good condition by dredging costs an enormous amount of money, the need will probably never decline. If it is not possible to change the shape and size of conventional ships, or if there is resistance to modifying estuaries to provide deep channels it would be best to locate ports for large vessels in the deep water of the coastal zone (for example Ems harbour in the north of The Netherlands). Future plans for new harbours should consider the advantages of this solution.

A successful example of changed land use can be found in England (European FRAME project). Dykes that were raised on the Alkborough flats along the east coast after the 1953 storm, are being removed. As a result, the Humber estuary (440 ha) will be changed from agricultural land into natural grass and estuary habitats. The river and sea are being given more space to flood and the intertidal flats will break the incoming waves. The saving in maintenance and building costs of the surrounding dykes is estimated at 18 million euros.

Drawing on contemporary experience and knowledge it would be easy to point the finger at past mistakes and wrong decisions. We cannot change history, but we can guide our own future and share with other countries the Dutch experience and changing views related to the exploitation of estuaries, not least because flood disasters and deteriorated ecosystems have transboundary and even global impacts. In summary, the lessons we have learned have led us to the following recommendations:

\section{1 'Look before you leap': \\ (lines!}

There is no way back after land reclamation and dyke construction: do not start this process! The 53 flood was a disaster waiting to happen, and it might happen again. The dependence on dykes and other infrastructure will always intensify over time so opting for short-term safety is inevitably connected to increasing long-term vulnerability. Moreover, once a dyke is built, people will always use the new land to the maximum: new investments are made, so the material impact of a disaster increases rapidly. In the end, ecological values will always decline, bringing sometimes unexpected side-effects.

\section{Realise that on-going costs are} higher than those for construction: maintenance and mitigation of

\section{side effects}

Maintenance costs are a perpetual expense. In the Dutch situation, the public pays several tens of millions of euro each year through their taxes. These costs will never decline but will only rise due to deterioration of the constructions. Besides, it takes a great deal of effort to minimise the (un)expected side-effects that inevitably follow the construction of large engineering works.

\section{Look for reversible measures}

When modification of the natural system seems to be inevitable, always try to use reversible measures: as knowledge develops, other solutions might be found which could still be applied. We cannot predict all the changes that will occur when an estuary is modified; the hydromorphological and ecological changes are still poorly understood. Experts should work on developing knowledge about estuarine systems while not forgetting that we cannot know everything. unexpected and very unpleasant side-effects will probably occur. This calls for reversible and flexible solutions. Better to be safe than sorry!

When irreversible changes have been made it might be possible to reduce their impacts, but the measures are usually very costly and the result will always be less than the original situation. The be action to undertake in a changed estuary is to minimise the increase of dependence on infrastructure. This can be done by restoring the natural processes wherever possible. Risk assessment should focus not only on minimising the risk of a disaster occurring but also on minimising the impact by not allowing large investments at vulnerable locations.

\section{Look for suitable economic drivers}

Try to develop economic drivers that are compatible with the natural conditions. Every landscape has its own characteristics which,
recognised and integrated into economic development strategies, will be spared extreme disturbance. In the end, suitable land use will turn out to be the best solution for both nature and society. The government should play an important role in this process by creating the correct policy and constitutional environment.

\section{Try to make a complete environmental} cost-benefit analysis

The value of (unaffected) ecosystems should be included in cost-benefit analyses as far as possible. The value of the safety that nature provides if we do not interfere is an example. At the same time, the intrinsic values of nature cannot be expressed in money, so the value will always be higher than can be calculated.

\section{Create public awareness related to} ecosystem functioning and safety Public participation may result in better understanding of ecosystems: how they function, the advantages they offer, the essentials of a dynamic system and the ecological coherence of an estuary. When the short- and long-term consequences of, for example, obstructing connectivity is explained, people will better understand the importance of an intact ecosystem. The result may be greater good will for sustainable developments, even if, for the shor term unpopular measures have to be taken such as giving land back to the sea. Creating awareness is a very important task for the government and for educational institutions.

\section{Consult a world-wide estuary expert} group

As shown in this report, lessons can be learned from countries that have experience with interference in estuaries. This knowledge should be used by others before new interventions take place in other systems. A group should be founded
to play this role. 


\section{Literature}

Chapter 2: Morphology and

man-induced changes

Berendse
Assen. Assen.

.

Asendsen, Henk J.A., and Esther Stouthamer, 2001 Palaeographic development of the Rhine-Meuse delta, The Netherlands. $268 \mathrm{pp}$.

Borger, G.J., 1992. Draining-digging-dredging; the creation of a new landscape in the peat areas of the low countries. In: J.T.A. Verhoeven (ed) Fens nutrient dynamics and conservation. Geobotany 18, p. 131-171.

Dekker, C., 1971. Zuid-Beveland. De historische geografie en de instellingen van een Zeeuws

eiland in de middeleeuwen. Van Gorcum, Assen. Esselink P., 2000? Nature management of coastal salt marshes; interactions between anthropogenic influences and natural dynamics.

Fischer, M.M. (ed), 1997. Holocene evolution of Zeeland (SW Netherlands). Mededelinge Nederlands Instituut voor toegepaste

geowetenschappen TNO, nr. 59, Haarlem

Coastlines of the Southern North Sea. Coastlines of the World Series. American Society of Civil Engineers, New York.

Huis in 't Veld, J. C., J. Stuip, A.W. Wather, J.M. van Westen, 1984. The closure of a tidal basin; closing of estuaries,

university

Laane, Remi, Ruud Hisgen, Arno van Berge Henegouwen, Rob Leewis en Franciscus Colijn 1990. De zee, de zee, de Noordzee. Rijkswaterstaat, Den Haag, 225 pp.

Meeuwsen, R., H. Pauwels, S. Wouda, I. de Vries and L. van Geldermalsen, 2002. Geslaagd inzicht; de lagenbenadering voor V\&W. (Pamphlet) Drukkerij Holland, Alphen a/d Rijn

Meire, P., M.Hoffmann and T.Ysebaert (red) 1995. De Schelde, een stroom natuurtalent. Instituut voor natuurbehoud, hasselt, rapport 1995.10

Mulder, F.J. de, e.a. (eds), 2003. De ondergrond van Nederland. Geologie van Nederland 7. Nederland Instituut voor toegepaste geowetenschappen TNO Utrecht

Nederlands Instituut voor Geowetenschappen TNO, 1997. De Ontstaangeschiedenis van het Zeeuwse kustlandschap; paleografie en bewoning in kaart /Landschap en bewoning in beeld. (Audiovisual Material), Delft

Oost, A.P. 1995. Dynamics and sedimentary

development of the Dutch Wadden Sea with

emphasis on the Frisian inlet, thesis University of Utrecht, $455 \mathrm{pp}$
Pluijm, A.M.van der and D.J. Jong, 1998. Historisch overzicht schorareaal in Zuidwest Nederland. Rijkswaterstaat, Rijkinstituut voor Kust en Zee, werkdocument RIKZ/OS-98.860

Pons, L.J., 1992. Holocene peat formation in the lower parts of the Netherland. In: J.T.A. Verhoeven (ed) Fens and bogs in The Netherlands: vegetation history, nutrient dynamics and conservation. Geobotany 18, p. 7-79.

Tooley, Michael J., \& Saskia Jelgersma (eds), 1992. Impacts of sea-level rise on European coastal lowlands. Blackwell, Oxford.

Verhulst, Adriaan, 1995. Landschap en landbouw in Middeleeuws Vlaanderen. Uitgave Gemeentekrediet

Visser, Jan, \& Robbert Misdorp (eds), 1998. Coastal dynamic lowlands - the role of water in the development of The Netherlands: past, present, future. Special features in coastal conservation 3. Journal of Coastal Conservation 4, p. 105-168. Opulus Press, Uppsala.

Wolf, P. de, 1990. De Noordzee. Terra, Zutphen. 200 $\mathrm{pp}$

Zagwijn, W.H. 1986. Nederland in het Holoceen geologie van Nederland. Deel 1. Rijks Geologische Dienst, Staatsdrukkerij, Den Haag 46 pp.

Chapter 3: Ecology: where river and sea meet

Anonymous, 1983. Integration of ecological aspects in coastal engineering projects. Rotterdam

Beaufort, L.F. de (red.), 1954. Flora en fauna van de Zuiderzee (thans IJsselmeer) na de afsluiting in 1932; verslag. De zuiderzee-commissie de nederlandse dierkundige vereniging, Den Helder.

Brongers M.en B. Spaans, 1990. Vegetatie en broedvogels van het Krammer-Volkerak en Zoommeer in 1989.RWS directie Flevoland, intern rapport.

1979. Ontwikkeling natuurfuncties Oosterschelde

Dord H. van, 1977. Natuurbouw in het Grevelingenbekken. RIJP Lelystad

erguson, H.A. \& W.J. Wolff, 1983. The haringvlietproject: the development of the Rhine-Meuse estuary from tidal inlet to stagnant freshwater lake. Wat. Sci.Tech. Vol. 16, pp. 11-26.

Huisman, J \& F.J. Weissing, 1999. Biodiversity of plankton by species oscillations and chaos. Nature $402,407-410$.

Jager, Z., 1999. Visintrek Noord-Nederlandse kustzone (inland fish migration in the northern Netherlands). Report RIKZ-99.022: 37 pp. (in Dutch). 
Jonge, V.N. de, 2000. Importance of temporal and spatial scales in applying biological and physic process knowledge in coastal management, an Research 20: 1655-1686.

Jonge, V.N. de \& D.J. de Jong, 2002. Ecological restoration in coastal areas in The Netherlands, concepts, dilemmas and some examples. In: P.H. Nienhuis \& R.D. Gulati (eds), Ecological Restoration of Aquatic and Semi-Aquatic Ecosystems in

The Netherlands (NW Europe), Hydrobiologia 478: 7-28.

Kamermans P., M.A. Hemminga \& D.J.de Jong, 1999. Significance of salinity and silicon levels for growt of a formerly estuarine eelgrass (Zostera marina) population (Lake Grevelingen, The Netherlands). Mar. Biol. 133, 527-539.

Katwijk M.M. van, G.H.W. Schmitz, Gasseling AP, van Avesaath PH, 1999. The effects of salinity and nutrient load and their interaction on Zostera martima L. Marine Ecology Progress Series 190: 155-165.

Klootwijk, M. en J. Kollen 1980. Inventarisatie en evaluatie van platen met een bestemming natuurterrein in het Deltagebied. RIJP, Lelystad.

Leeuw C.C. \& J.J.G.M. Backx, 2001. Naar een herstel van estuariene gradiënten in Nederland; een literatuurstudie naar de algemene ecologische proncipes van estuariene gradiënten t.b.v. herstelmaatregelen langs de Nederlandse kust. RIKA/RIKZ

Loenen, M. (red.), met bijdragen van P.J. Ente,

J. Visser, H.J. Drost en M.J.H.P. Pinkers 1981.

Perspectief voor natuur op buitendijkse gronden van Haringvliet, HollandsDiep, Krammer-Volkerak en Grevelingen. RIJP Lelystad

Loenen M. (red.), met bijdragen van H.J. Dost, . Visser, L. Zwarts en M. Loenen, 1985. Facetplan natuur Krammer-Volkerak. RIJP, Lelystad

Michaelis, H., H. Fock, M. Grotjahn \& D. Post, 1992. The status of the intertidal zoobenthic brackishwater species in estuaries of the German Bight. Neth. J. Sea Res. 30:201-207.

Nienhuis P.H., 1978. Lake Grevelingen; a case study of ecosystem changes in a closed estuary. Delta institute for hydrobiological research, Yerseke.

Nienhuis P.H., 1978. Lake Grevelingen; van estuarium naar zoutwatermeer. Delta institute for

hydrobiological research, Yerseke.

Nienhuis, P.H., 1982. De ecologische conwequenties van de Deltawerken. In: W.J.Wolf (ed) Wadden duinen, delta, pp. 101-132. Biologische Raad Reeks. Pudoc Wageningen.

Remane, A., 1934. Die Brackwasserfauna. Verh. Deutsch. Zool. Ges. 36: 34-74 (in German).
Schmidt van Dorp, A. D., 1979. Literatuuronderzoek naar de soortenrijkdom van het makrozoobenthos in relatie tot het zoutgehalte. [literature review of species richness of macrozoobenthos in relation to salinity] DHHO, rapporten en verslagen nr. 1979-5 (in Dutch).

Sfriso, A. \& A. Marcomini, 1997. Macrophyte production in a shallow coastal lagoon. Part I: coupling with chemico-physical parameters and nutrient concentrations in waters. Mar. Envir. Res. 44: 351-375.

Sfriso, A. \& A. Marcomini, 1997. Macrophyte production in a shallow coastal lagoon. Part II:
coupling with sediments, SPM and tissue carbon nitrogen and phosphorus concentrations. Mar. Envir. Res. 47: 285-309.

Sfriso, A., B. Pavoni, A. Marcomini \& A. A. Orio, 1992 Macroalgae, nutrients cycles and pollutants in the lagoon of Venice. Estuaries 15: 517-528.

Sijmons D.F. and M. Loenen, 1980. Een verkenning van potentiële verstoringen van de ornithologische functie van het Oosterscheldegebied t.g.v. recreatief gebruik. RIJP, Lelystad

Tosserams, M., E.H.R.R. Lammens and M. Platteeuw, 2000. Het Volkerak-Zoommeer; de ecologische ontwikkeling van een afgesloten zeearm. RIZA Lelystad

Witteveen, H. 1977. Natuurlijke ontwikkeling slikken van Zonnemaire Grevelingenbekken. RIJP, Lelystad Wolff W.J., P. de Koeijer, A.J.J.Sandee \& L. de Wolf, 1967. De verspreiding van Rotganzen in het Deltagebied in relatie tot de verspreiding van hun voedsel. Limosa 40 no. 41967 pp. 163-174

Chapter 4: Socio-economic developments

Flameling, I, 2003. Hoogwater; 50 jaar na de watersnoodramp. Ministerie van verkeer en

waterstaat, Den Haag
Het Vrije Volk, 7 February 1953. Belgium newsletter article

Koninklijk Instituut voor het Duurzame Beheer van de Natuurlijke Rijkdommen en de Bevordering van Schone Technologie (KINT), 1999. Hoogwaterstanden en overstromingen in België, Een socio-economische benadering, De verhandelingen van het KINT, pp. 45.

Slager, K., 2003. De ramp; een reconstructie van de watersnood van 1953. Uitgeverij Atlas, Amsterdam/ Antwerpen

Whitmarsh D., Northen J., Jaffry S., 1999. Recreational Benefits of coastal protection: a cas study, Marine Policy 23 (4-5), 453-463.
Chapter 5: Rationale of decision making in water management and spatial planning

Ast J.A. van, J.J.Bouma \& D.Francois, 2003. Waardering van overstromingsrisico's. Ministry of transport and water management, ESM Rotterdam

Bartosova, A., D.E. Clark, V. Novotny and K. S. Taylor, 1999. Using GIS to evaluate the effects of flood risk on residential property values Proc. Environmental Problem Solving with Geographica Information Systems: A National Conference, U.S. EPA, Cincinnati, Ohio, September 22-24

Bouma, J.J. \& H.L.F. Saeys, 2000. Eco-centric cost-benefit analysis for hydraulic engineering in river basins. In: Smits A.J.M., P.H. Nienhuis \& R.S.E.W. Leuven, 2000. New approaches to river management, pp 167-178. Backhuys publishers, Leiden

Constanza et al, 1997. The Value of world's ecosystem services and natural capital. Nature, vol.387, 15 May 1997.

Dantzig, D. van, 1959. The economic decision problem related to flood management in The Netherlands (in Dutch). In: Report Delta Commission, Contribution II.2, Research with importance to the design of dykes and dams, 58-110.

Daun, M.C., Clark, D., 2000. Flood risk and contingent valuation willingness to pay studies: a methodological review and applied analysis, Technical Report No. 6, Risk Based Urban Watershed Management - Integration of Wate Quality and Flood Control Objectives, pp. 85.

DWW (Dienst Weg- en Waterbouwkunde), 2001. Economic insights into the River and Land Concep (in Dutch), DWW-2001-099, Ministry of Transport, Public Works and Water Management, Delft.

Heertje, A., 2002. Economie in een notendop; wat iedereen van de economie moet weten. Uitgeverij Prometheus, Amsterdam

Schuijt, K., 2001. The economic value of lost natural functions of the Rhine river basin, Costs of huma development of the Rhine river basin ecosystem, Erasmus Universiteit Rotterdam, Publikatiereeks nr. 36 , pp. 42

Simonovic, S.P., 1999. Social criteria for evaluation of flood control measures: Winnipeg case study Urban Water 1, 167-175.

Turner, R.K., Bateman, I.J. and Adger W.N. (Eds.), 2001. Economics of Coastal and Water Resources: Valuing Environmental Functions, Kluwer Academic Publishers, pp. 43, Dordrecht.

Turner, R.K., Pearce, D. and Bateman, I.J., 1994. Environmental Economics, An elementary introduction, Harverster Wheatsheaf, pp. 328,
New York.
Tinbergen, J., 1959. Socio-economic aspects of the Delta Plan (in Dutch). In: Report Delta Commission Contribution VI, Research with importance to the design of dykes and dams, 66-74

Chapter 6: Decision-making in a changing context

Ast, Jacko van, 2000. Interactief watermanagement in grensoverschrij dende riviersystemen (interactive water management in transboundary river systems), proefschrift Erasmus Universiteit Rotterdam, Eburon.

Bergh, E. van den, S. Van Damme, J.Graveland D.J. de Jong, I.Baten and P.Meire 2003. Voorstel voor natuurontwikkelingsmaatregelen ten behoeve van de Ontwikkelingsschets 2010 voor het Schelde-estuarium.

Werkdocument/RIKZ/OS/2003.825x

Bergh, Erika Van den, Patrick meire,

Maurice Hoffmann en Tom Ysebaert, 1999. Natuurherstelplan Zeeschelde: drie mogelijke inrichtingsvarianten. Instituut voor Natuurbehoud, Brussel. rapport IN 99/18

Bolhuis, Dr. ir. E.E., en mr. J.D. Eiersma, 1996. Natuurlijk water, ook voor later. Berenschot Euromanagement

Boo, M. de, 2002. Stagnatie in de delta; provincie wil meer dynamiek in de Zeeuwse wateren. 9-11-2002 NRC Handelsblad. p. 35

Hennisen, Jos en Patrick Meire, 1998. Inrichting van het gecontroleerd overstromingsgebied KruibekeBazel-Rupelmonde. Instituur voor natuurbehoud, Brussel. Rapport IN 98/32

Koninklijk Instituut voor het Duurzame Beheer van de Natuurlijke Rijkdommen en de Bevordering van Schone Technologie (KINT), 2001.

Hoogwaterstanden en overstromingen in België, Een evaluatie van de niet-tastbare kosten, De verhandelingen van het KINT, pp. 47.

Oliveri, E. and Santoro, M., 2000. Estimation of urban structural flood damages: the case study of Palermo, Urban Water 2, 223-234.

vermars, Willem en Wouter Helmer, 1999. Gecontroleerd Overstromingsgebied KruibekeBazel-Rupelmonde. Ministerie van de Vlaamse Gemeenschap, Afdeling Natuur, Brussel.

Shabman, L. and Stephenson, K., 1996. Searching for the correct benefit estimate: empirical evidence for an alternative perspective, Land Economics 72(4), 433-449.

Slager, K., 2003. De ramp; een reconstructie van de watersnood van 1953. Uitgeverij Atlas, Amsterdam/ Antwerpen

Tinbergen, J., 1959. Socio-economic aspects of the Delta Plan (in Dutch). In: Report Delta Commission Contribution VI, Research with impo
design of dykes and dams, 66-74 


\section{Acknowledgements}

Meyvis, Leo, zj, ca 2003. Naar een nieuw sigmaplan. Kennismaking met het Zeescheldebekken

Brochure AWZ, afdeling zeeschelde.

Schultz van Haegen, Melanie, staatssecretaris van Verkeer en Waterstaat, 2003. Geen dag zonde risico's. Cleveringalezing, Universiteit Leiden.

Wolters, Ard, Jarl Kind, Martine Brinkhuis, Alex Roos, Stephanie Holterman, zj. Veiligheidsnormen en

het perspectief van houdbaarheid. De tot

standkoming van de Wet op de Waterkering.

Notitie Rijkswaterstaat.

\section{Chapter 7:Lessons learned and} solutions proposed

Jonge, V.N. de, 1983. Relations between annual dredging activities, suspended matter concentrations, and the development of the tidal regime in the Ems estuary. Can. J. Fish. Aquat. Sci. 40 (Suppl. 1): 289-300.

Jonge, V.N. de \& D.J. de Jong, 2002. 'Global Change' impact of inter-annual variation in water discharge as a driving factor to dredging and spoil disposal in the river Rhine system and of turbidity in the Wadden Sea. Estuarine Coastal Shelf Science 55 : 969-991.
Jonge, V.N. de \& D.J. de Jong, 2002. Ecological restoration in coastal areas in The Netherlands, concepts, dilemmas and some examples. In: P.H. Nienhuis \& R.D. Gulati (eds), Ecological Restoration of Aquatic and Semi-Aquatic Ecosystems in The Netherlands (NW Europe), Hydrobiologia 478

Kuijpers J.W.M. 1995. Ecological restauration of the Rhine-Maas estuary. Ministry of transport public works and water management dep. SouthHolland, Rotterdam

Smit, H., R. Smits \& H. Coops 1994. The Rhine-Meuse delta: ecological impacts of enclosure and prospects for estuary restauration. RIKZ nr. AB-94.837X, Den Haag

Winden, A.van, W. Overmars, G. Litjens and

W. Helmer. Nieuw Rotterdams Peil; Stad en natuur in de monding van de Rijn en Maas. 1997.

Stroming b.v., pp. 1-63

\section{Editing: \\ Liz Hopkins}

\section{Maps}

W.Overmars: 1, 2, 15, 17, 20,21,22,24,25,26, 28, 57

TNO-NITG and RIKZ: 9, 10, 11, 12, 13,14

I. de Vries, (after) 42,44

, $46,48,49,50$

Brochure De Schelde, een stroom natuurtalent: (after) : 7

\section{Photos}

Rijkswaterstaat: Front Cover, 6, 8, 23, 29,

$30,36,39$

Satellite View of the Delta (53): copyright Sat5 Nero Amersfoort. Made available by the Province of Zeeland.

\section{Graphs}

N. de Jonge: 31,32

\section{Artist Impression}

Jeroen Helmer, 47

\section{Graphic Design}

Jolanda Hiddink, Graphic Department, Radboud University Nijmegen

\section{Print}

XXL-press, Nijmegen, The Netherlands

\section{Reference}

Erasmus University Rotterdam

Radboud University Nijmegen

Changing estuaries, changing views.

Nijmegen 2004

\section{Keywords}

Dutch-Flemish estuary, Rhine-Meuse-Scheldt estuary, wetlands, restoration, sustainable use, Delta Works, safety, storm-surge barrier

\section{Commissioned by}

Worldwide Fund for Nature, The Netherlands 
Hier komt de uitklapbare kaart 